\title{
Dynamics of physical processes in proteins studied by kinetic absorption spectroscopy
}

\author{
Ph.D. Dissertation
}

\author{
Petro Khoroshyy
}

\author{
Supervisor: Prof. László Zimányi \\ Institute of Biophysics, Biological Research Centre \\ of the Hungarian Academy of Sciences, Szeged
}

Doctoral School of Biology, Faculty of Science and Informatics,

University of Szeged

2013

Szeged 


\section{Table of Contents}

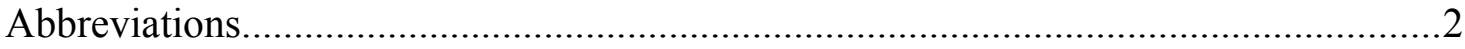

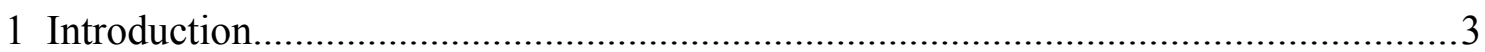

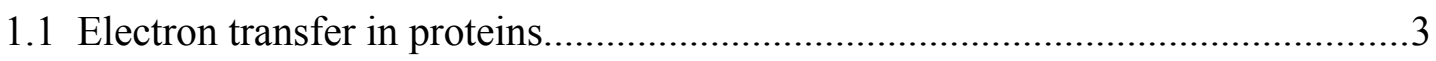

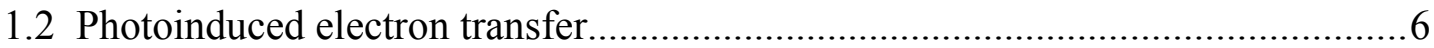

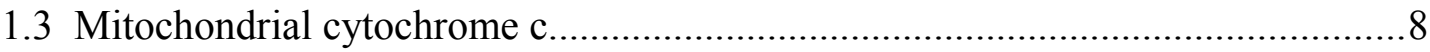

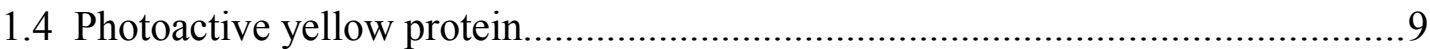

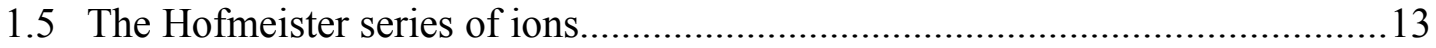

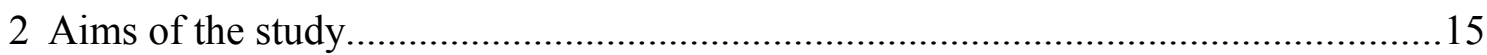

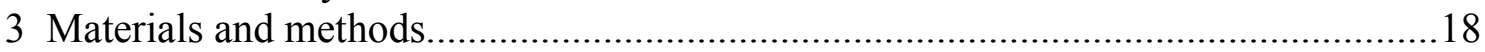

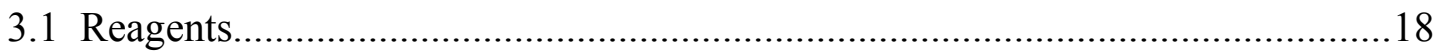

3.2 Recombinant cytochrome c expression and purification.................................. 18

3.3 Preparation of TUPS-lysine and TUPS-cystamine derivatives...........................18

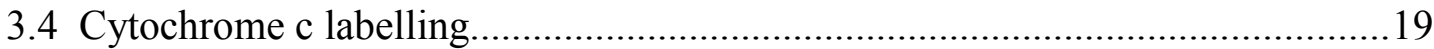

3.5 UV-VIS stationary and transient spectroscopy measurements.........................20

3.6 Molecular dynamics and electron transfer parameter and pathway calculations 21

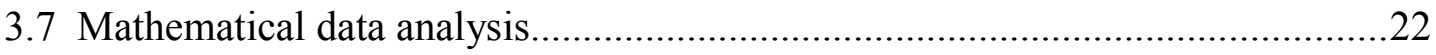

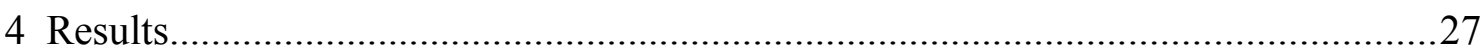

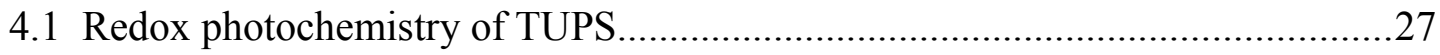

4.2 Electron transfer in singly labelled cytochrome $\mathrm{c}$ derivatives............................31

4.3 Molecular dynamics and electron transfer parameter and pathway calculations 38

4.4 The photocycle of photoactive yellow protein...................................................42

4.4.1 Singular value decomposition (SVD) and multiexponential fit..................43

4.4.2 Target testing to determine the input intermediate spectra .........................48

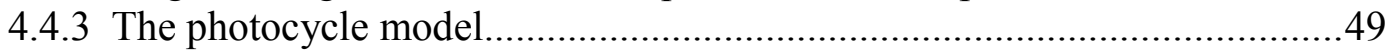

4.4.4 Intermediate kinetics as a function of cosolutes .......................................53

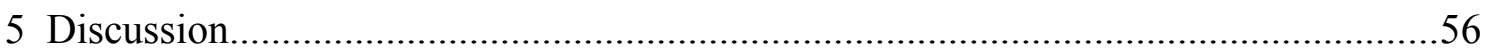

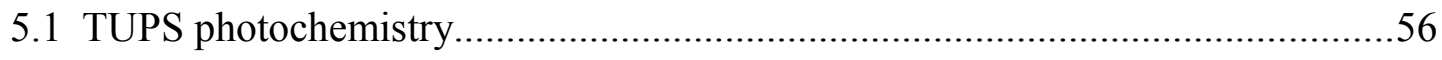

5.2 Electron transfer in singly labelled TUPS-cytochrome $\mathrm{c}$ derivatives.................57

5.3 PYP photocycle at moderately alkaline $\mathrm{pH}$ and its modulation by HE...............59

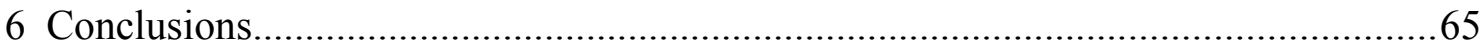

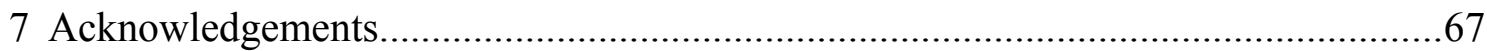

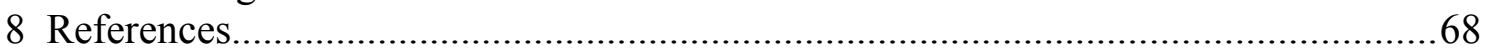

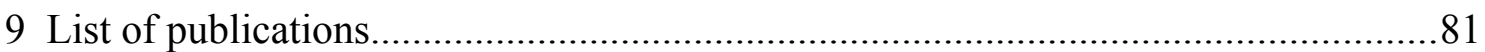

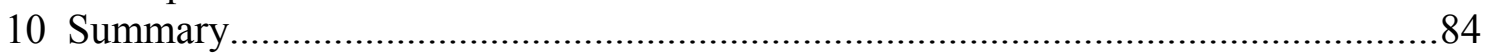

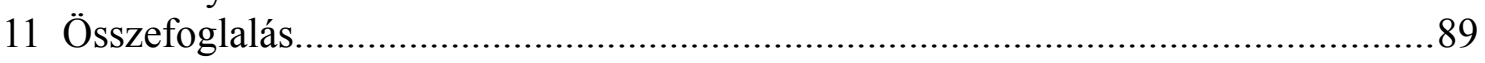




\section{Abbreviations}

HE - Hofmeister effect

IPTS - 1-isothiocyanato-pyrene-3,6,8,-trisulfonate

MD - molecular dynamics

MEM-NLS - maximum entropy minimisation nonlinear-least-squares

PAS - Per Arnt Sim

$\mathrm{pB}_{1}$ - first blue shifted intermediate of the PYP photocycle

$\mathrm{pB}_{2}-$ second blue shifted intermediate of the PYP photocycle

pCA - p-coumaric acid

pG - resting form of PYP

$\mathrm{pR}_{1}-$ first red shifted intermediate of the PYP photocycle

$\mathrm{pR}_{2}-$ second red shifted intermediate of the PYP photocycle

PYP - photoactive yellow protein

SVD - singular value decomposition

TUPS - 8-thiouredopyrene 1,3,6-trisulfonate

TUPS $^{-}$- negative-radical of 8-thiouredopyrene 1,3,6-trisulfonate

TUPS $^{*}$ - triplet excited state of 8-thiouredopyrene 1,3,6-trisulfonate

TUPS $^{+}$- positive-radical of 8-thiouredopyrene 1,3,6-trisulfonate 


\section{Introduction}

\subsection{Electron transfer in proteins}

The transfer of electrons from one molecule to another is an important process in biology, particularly in bioenergetic pathways. Electron transfer reactions in biological systems occur between cofactors buried inside the protein matrix, and can span distances up to $25 \AA$ (Cramer and Knaff, 1990; Gray and Halpern, 2005). Long-range non-adiabatic electron transfer processes are explained by Marcus' theory, which predicts an exponential process with a rate which depends on a number of parameters (DeVault and Sutin, 1980; Marcus and Sutin, 1985):

$$
k_{E T}=\frac{2 \pi}{\hbar} H_{D A}^{2} F C
$$

Here $\mathrm{k}_{\mathrm{ET}}$ is the electron transfer rate between donor (D) and acceptor (A) held at a fixed distance, $\hbar$ is the reduced Planck constant $\left(\mathrm{h} / 2 \pi ; 1.055 \times 10^{-34} \mathrm{~J} \times \mathrm{s}\right), \mathrm{H}_{\mathrm{DA}}$ is the electronic coupling between donor and acceptor at the nuclear configuration of the transition state. FC is the so-called Franck-Condon factor, which relates the free energy of the reaction $\left(\Delta \mathrm{G}^{\circ}\right)$ with the reorganization energy $(\lambda)$. The reorganization energy is the amount of energy required to change the nuclear coordinates of the products to those of the reactants without actual electron transfer. If the sum of all nuclear motions is treated as independent oscillators and all vibrational frequencies $\left(\mathrm{V}_{\mathrm{i}}\right)$ are relatively small $((\mathrm{h} \vee / 2 \mathrm{kT}) \leq 1)$, FC can be written as (DeVault and Sutin, 1980):

$$
F C=\frac{1}{h^{2} \lambda k_{B} T} e^{\frac{-\left(\Delta G^{o}+\lambda\right)^{2}}{4 \lambda k_{B} T}}
$$

Here $\mathrm{h}$ is Planck's constant, $\mathrm{T}$ is absolute temperature $(\mathrm{K})$, and $\mathrm{k}_{\mathrm{B}}$ is the Boltzmann constant. The multidimensional movement of the reactants' nuclei can be approximated by a simple harmonic motion along a reaction coordinate $\mathrm{Q}$ and represented as a parabolic well with the equilibrium potential on the bottom (Figure 1.1, left). To depict the products' nuclear motion, a parabola of the same shape, shifted along the reaction coordinate from $\mathrm{Q}_{1}$ (reactants) to $\mathrm{Q}_{2}$ (products), and along the energy coordinate by $\Delta \mathrm{G}^{\mathrm{o}}$, is used. By a simple calculation a quadratic relation between $\Delta \mathrm{G}^{\mathrm{o}}, \lambda$ 
Introduction

and the activation energy of the electron transfer reaction $\left(\Delta \mathrm{G}^{\ddagger}\right)$ is derived (DeVault and Sutin, 1980):

$$
\Delta G^{t}=\frac{\left(\Delta G^{o}+\lambda\right)^{2}}{4 \lambda}
$$

This shows that, as long as $-\Delta \mathrm{G}^{\mathrm{o}}<\lambda$, the rate of electron transfer increases upon decrease of the (negative) value of the driving force. This is the so called normal region. The electron transfer rate is maximal when $-\Delta \mathrm{G}^{\mathrm{o}}=\lambda\left(\Delta \mathrm{G}^{*}=0\right.$, Figure 1.1, right). Further decrease (i.e. more negative value) of the driving force causes a decrease in the electron transfer rate, in the so-called "inverted region", $-\Delta \mathrm{G}^{\mathrm{o}}>\lambda$ (Marcus, 1997).

$\mathrm{H}_{\mathrm{DA}}$ is defined as an overlap of the donor and acceptor orbitals as well as orbitals of the medium between the two. It shows roughly exponential dependence on distance $\mathrm{R}$ (§) (Hopfield, 1974; Moser et al., 2000).

$$
H_{D A} \propto \exp (-0.5 \beta R)
$$

The $\beta$ coefficient in this expression represents the influence of the intervening medium on the electron transfer. Its value for electron tunnelling in vacuum is 3.4 , and an average value for protein mediated electron transfer is 1.4 (Hopfield, 1974). A single,

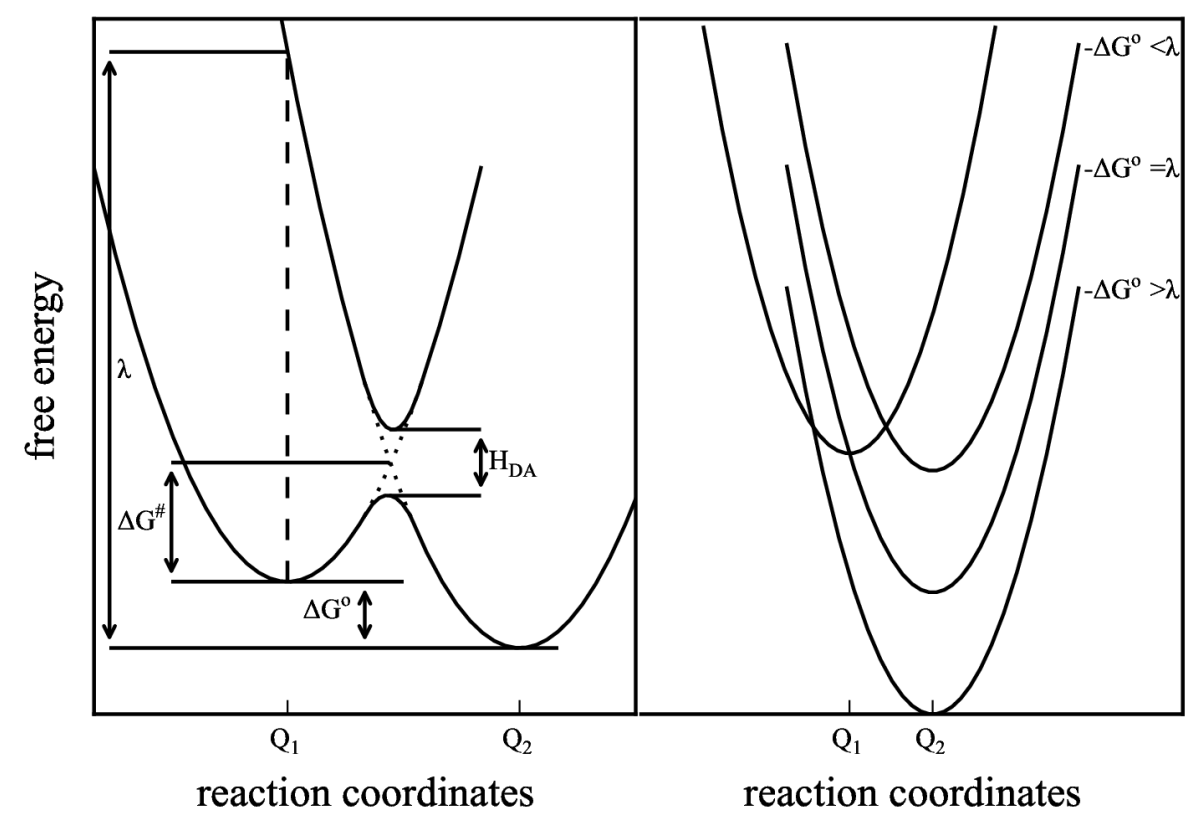

Figure 1.1 Intersecting parabolas used to represent reactant (pre-electron transfer) and product (post-electron transfer) energy surfaces as classical harmonic oscillators (left). Dependence of the activation energy on the relative values of $\Delta G^{o}$ and $\lambda$ (right). 
unique account of the role and significance of the protein medium in the electron transfer is still not completely established, with two main theories existing in parallel. One group of researchers considers the protein matrix as a uniform isolating barrier (Moser et al., 1992; Moser et al., 2008) whose properties are defined by an average atom packing density $(\rho)$ between donor and acceptor. A semi-empirical expression for electron transfer rates developed on this assumption and Marcus' electron transfer theory is (Moser et al., 2000):

$$
\log \left(k_{E T}\right)=13-(1.2-0.8 \rho)(R-3.6)-3.1 \frac{\left(\Delta G^{o}+\lambda\right)^{2}}{\lambda}
$$

where $\lambda$ and $\Delta \mathrm{G}^{\mathrm{o}}$ are in $\mathrm{eV}, \mathrm{R}$ in $\AA$. An extensive study on available structures of redox proteins, by the same authors, shows that distance plays a decisive role in determining their design. Most of edge-to-edge distances fall in the range from near van der Waals contact to $14 \AA$, with very few exceptions beyond this limit. From this the authors conclude that natural design of redox proteins is achieved solely by placing cofactors close enough to ensure sufficient electron transfer rate for normal enzyme turnover, and the design of a specific electron transfer path is not needed (Moser et al., 2006).

In the other interpretation the chemical composition and secondary and tertiary structural elements are explicitly taken into account in calculating the optimal electron transfer pathway connecting donor and acceptor. The electron is assumed to follow a path consisting of several covalent bonds, hydrogen bonds and through space jumps between atoms without bonds, each of which assigned to a unique coupling decay value. Electronic coupling is then calculated as a product of the couplings of each individual step (Gray and Winkler, 1996a):

$$
H_{D A}=\prod_{i} \epsilon_{C}(i) \prod_{j} \epsilon_{S}(j) \prod_{k} \epsilon_{H}(k)
$$

where $\varepsilon_{\mathrm{c}}, \varepsilon_{\mathrm{s}}, \varepsilon_{\mathrm{H}}$ are dimensionless couplings for the covalent bond $(\exp (-0.8 \times \mathrm{R}))$, the space jump $(\exp (-3.4 \times \mathrm{R}))$ and the hydrogen bond $\left(\varepsilon^{2} \times \exp (-1.7 \times(\mathrm{R}-2.8))\right.$, respectively.

Both theories have their supporters, and pro and contra arguments. The sizeable scattering of the values of the rates for long range electron transfer about the expected simple exponential distance dependence is stated as the reflection of sensitivity of electronic coupling to protein structure and the incompatibility with the uniform barrier assumption (Regan et al., 1993). Reevaluation of the data on heme proteins by Moser et 
al. (2008), using edge-to-edge distances instead of the distance from the central Fe ion, decreased the disagreement between the uniform barrier prediction and experimental data. Generally, the absence of a clear view about the edge of certain cofactors complicated the comparison of the experimental data. In the pathway theory, however, the existence and interaction of multiple pathways is ignored. The attempt to overcome this led to the development of the more detailed "worm" model of electron transport (Kawatsu et al., 2001) and the "tunneling tubes" approach (Curry et al., 1995; Balabin and Onuchic, 2000).

\subsection{Photoinduced electron transfer}

The ability of light to synchronize the initiation of electron transfer reactions, whose rate is often in the submicrosecond timescale, is a desirable feature. Using short laser pulses this is readily achieved in photosynthetic complexes (Sétif and Bottin, 1995). The introduction of photoactive redox reagents allows to measure electron transfer in systems which are not sensitive to light under usual conditions (Czege and Kovacs, 1989). However, the time resolution is limited by the rate constant of the intermolecular reaction between the photo-produced redox mediator and the protein under investigation. Moreover, the relative location and the distance between donor and acceptor is usually unknown in such an approach, narrowing its use in the research of electron transfer mechanisms. To overcome the limitations mentioned above, a number of covalent complexes between proteins and photoactivated redox labels were developed. These are organo-metallic complexes of ruthenium attached to cysteine, histidine or lysine amino acid side chains, used mainly in electron transfer studies. The metal-to-ligand charge transfer state formed upon excitation of ruthenium compounds exhibits strong reducing properties. The modification of the metal coordinating ligands allows the tuning of the midpoint redox potential. A number of compounds with redox potential in the range from -0.87 to $-0.37 \mathrm{~V}$ have been synthesized (Millett and Durham, 2002; Engstrom et al., 2003; Geren et al., 2009; Durham and Millett, 2012), and after covalent or electrostatic attachment, successfully applied as electron donors to different redox centers within the protein matrix, including heme (myoglobin (Cowan et al., 1988), cytochrome $c$, cytochrome $c$ oxidase (Durham and Millett, 2012), blue copper (Bechtold et al., 1986) and iron-sulfur sites (Sola et al., 1989)). To monitor the events 

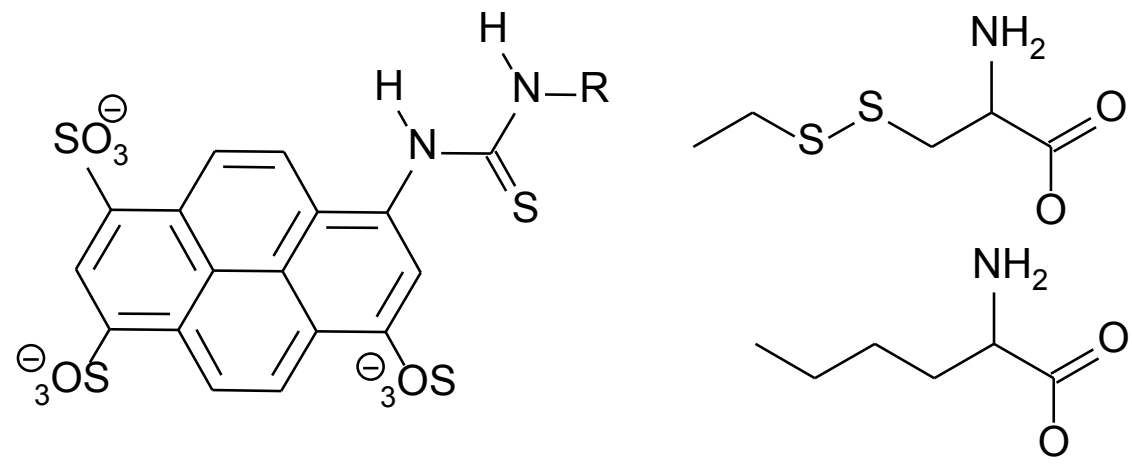

Figure 1.2 8-thiouredopyrene 1,3,6-trisulfonate (left). $R$ is any of the radicals depicted on the right. The upper form of the radical is formed upon cysteine residue labelling, the bottom radical when a precursor is used to label lysine amino acids in a protein.

which follow the initiation of electron transfer, a range of spectroscopic methods can be employed. These methods allowed the direct measurement of electron transfer rates within (Bjerrum et al., 1995) or between proteins (Geren et al., 1995; Engstrom et al., 2003), as well as the rates of redox-coupled proton transfer (Ruitenberg et al., 2000). In addition, from the measured rates further parameters can be estimated, such as the reorganization energy of electron transfer (Di Bilio et al., 1997).

Other methods of rapid generation of reductive agents for electron transfer initiation include: photoexcitation of proteins with $\mathrm{Zn}$ substituted heme (PetersonKennedy et al., 1984), and solvated electron or/and radical production by pulse radiolysis (Kotlyar et al., 1996; Kotlyar and Borovok, 1997). A specific technique is based on carbon monoxide ( $\mathrm{CO}$ ) bound ferrous heme. The highly reductive product generated upon photodissociation of this complex is widely used to study the enzymatic mechanism of cytochrome $c$ oxidase and other terminal oxidases (Boelens et al., 1982).

Thiouredopyrene-trisulfonate (TUPS) was introduced to the field by the group of Kotlyar as an alternative to ruthenium derivatives (Kotlyar et al., 1997a). As shown in the left side of Figure 1.2, it is a pyrene derivative with 3 sulfonate groups in positions $1,3,6$ and thiourea in the $8^{\text {th }}$ position. The radical at the second nitrogen atom of thiourea differs depending on the employed protein labelling procedure as depicted on the right side of the picture. The top radical is formed during labelling proteins at cysteine amino acids (Kotlyar et al., 1997b), while the reaction between the TUPS precursor IPTS (1-isothiocyanato-pyrene-3,6,8,-trisulfonate) and lysine sidechains results in the 
derivative with the bottom radical (Kotlyar et al., 2000). Upon one photon excitation of TUPS, a long lived TUPS triplet is formed (TUPS ${ }^{*}$ ). The triplet can efficiently donate an electron to appropriate electron acceptors with the resulting formation of a TUPS positive radical $\left(\right.$ TUPS $\left.^{+}\right)$. Due to the low redox potential of the TUPS*/TUPS ${ }^{+}$pair $(-0.9$ $\mathrm{V})$ and the long lifetime of the triplet excited state $(0.5 \mathrm{~ms})$, this label was successfully used to initiate reductive electron transfer in several biological systems. Moreover, the TUPS triplet (the TUPS-TUPS* pair) exhibits oxidative properties in the presence of appropriate electron donors, a phenomenon which has been exploited to a much lesser extent.

\subsection{Mitochondrial cytochrome c}

Mitochondrial cytochrome $c$ is a small globular heme protein found in the inter-membrane space of mitochondria. It is one of the first discovered respiratory enzymes (Keilin, 1925). Using heme as a redox mediator, it shuffles electrons between complex III (a.k.a. $b c_{1}$ complex or ubiquinol-cytochrome $c$ oxidoreductase) and complex IV (cytochrome $c$ oxidase) of the respiratory chain (Berg et al., 2006). Mitochondrial $c$ cytochromes consist of 100-120 amino acids (Banci et al., 1999) and have an average molecular mass of about $12 \mathrm{kDa}$.

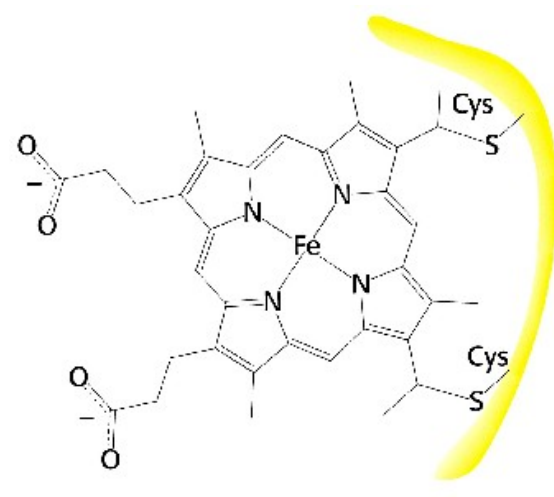

Figure 1.3 Heme c binds to the polypeptide chain via thioether bonds, from Lehninger et al. (2005) According to the classification of Ambler (1991), they belong to class I of the cytochrome $c$ superfamily and, as all proteins of this group, they contain heme c, covalently bound to the protein moiety via two thioether bonds (Figure 1.3). The heme binding cysteines appear in the highly conserved $\mathrm{CXXCH}$ motif near the $\mathrm{N}$-terminus of the polypeptide. The cartoon representation of the structure of horse heart cytochrome $c$ is shown in Figure 1.4. Five helices with interconnecting loops construct the hydrophobic crevice, surrounded by non-polar amino acid residues, where the heme is located. The N-terminal $\alpha_{1}$, and the C-terminal $\alpha_{5}$ and $\alpha_{3}$-helices (in mitochondrial cytochromes $c$ also called 60's helix) form the cytochrome $c$ superfamily fold (Figure 1.4) (Chothia and Lesk, 1985; Bertini et al., 2006). The histidine from the CXXCH signature sequences and a methionine sulfur, placed closer to the $C$ terminal end, serve 


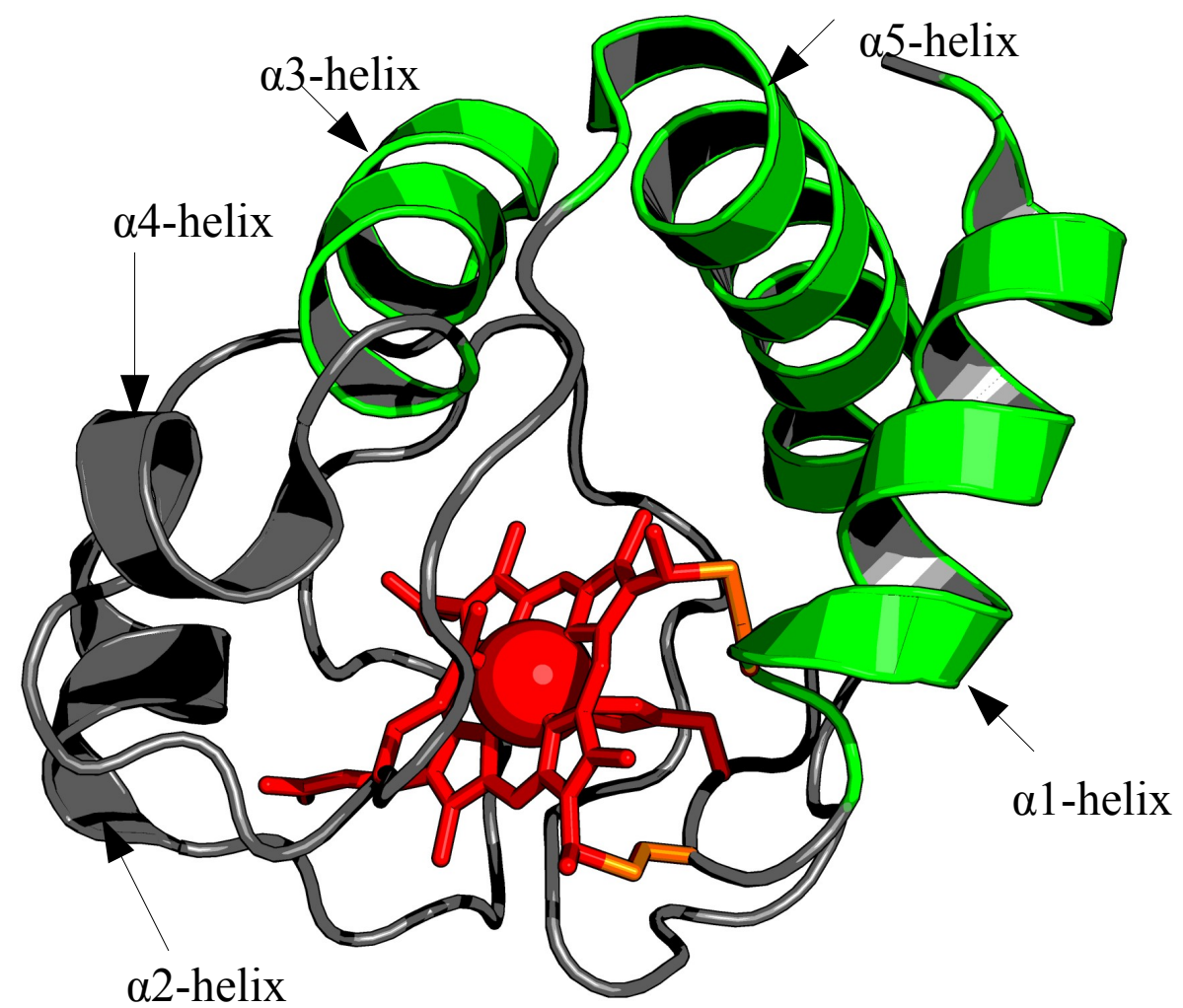

Figure 1.4 Cartoon representation of the horse heart cytochrome $c$ structure. Heme $c$ and axial ligands - red, heme binding cysteines orange, cytochrome c fold highlighted in green. Generated by PYMOL from the $1 H R C$ pdb file.

as the two axial ligands of the heme iron. The heme iron ion can be in the reduced state $\left(\mathrm{Fe}^{2+}\right.$, ferrocytochrome $\left.c\right)$ or in the oxidized state $\left(\mathrm{Fe}^{3+}\right.$, ferricytochrome $\left.c\right)$. The heme redox potential is highly conserved in the group in the range of $260 \pm 20 \mathrm{mV}$ (Keilin, 1966; Margoliash and Schejter, 1966). About a decade ago, research interest in cytochrome $c$ was intensified by the discovery of its role in the apoptotic pathway (Liu et al., 1996). Recent developments in the topic were reviewed by Ow et al. (2008). Due to its high thermodynamic stability and solubility, as well as the presence of its spectrally active cofactor, mitochondrial cytochrome $c$ is used as a popular model protein to study different aspects of protein chemistry and physics (Pinheiro, 1994; Shastry et al., 1998; Lee et al., 2002), and electron transfer within and between proteins in particular (Gray and Winkler, 1996b).

\subsection{Photoactive yellow protein}

Photoactive yellow protein (PYP) was discovered in the purple photosynthetic 
bacterium Halorhodospira halophila (Ectothiorhodospira halophila) (Meyer, 1985). PYP consists of 125 amino acids, and its intense yellow colour is due to its p-coumaric acid (4-hydroxy-cinnamic acid) chromophore (Figure 1.5) bound via a thioesther bond to Cys69 (Baca et al., 1994). Sequence and structure comparison studies (Pellequer et al., 1998) revealed the high similarity of PYP to the Per-Arnt-Sim (PAS) domain. The PAS domain name comes from the three proteins where the fold occurs: Per - period circadian protein, Arnt - aryl hydrocarbon receptor nuclear translocator protein, Sim - single-minded protein (Ponting and Aravind, 1997). Similarly to other proteins of this family, often found in pathways that regulate responses to environmental change (McIntosh et al., 2010), PYP serves as photosensor for phototaxis of the host bacteria (Sprenger et al., 1993). Although no partner of PYP along a putative signal transduction pathway has so far been identified, one candidate is the Che system (Hoff et al., 2009).

Crystal (Borgstahl et al., 1995) and NMR (Düx et al., 1998) structures of the

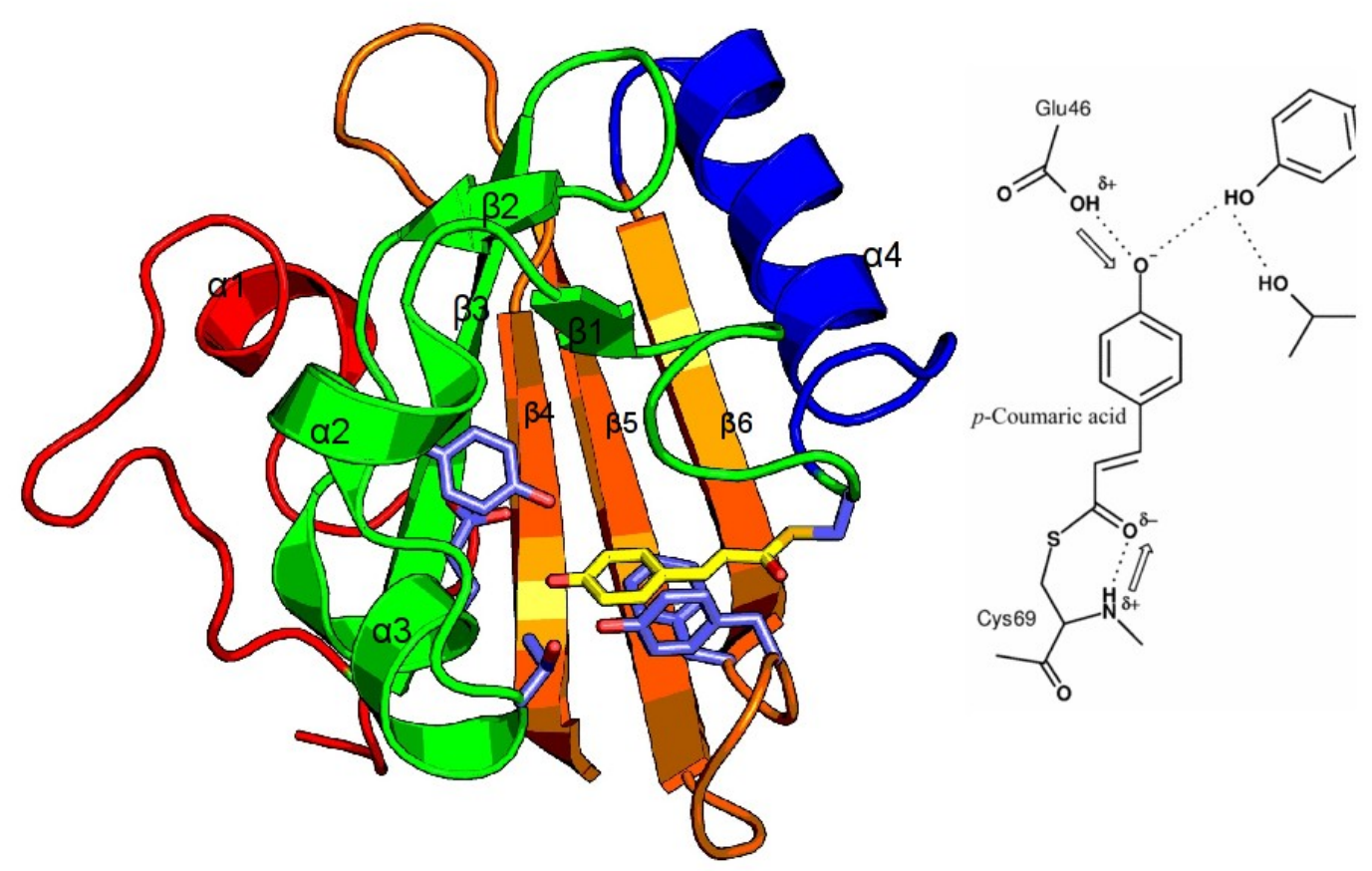

Figure 1.5 Left: Structure of PYP. Generated by PYMOL from $3 P H Y$ pdb entry. $N$ terminal cap (red), $\beta$-scaffold (orange), helical connector (blue), PAS core (green). Right: Schematic diagram of p-coumaric acid and residues around the chromophore (from Sugishima et al. (2004)) 
resting state of PYP (i.e. before photoexcitation) are available, and show that it has an $\alpha / \beta$-fold, divided into four sections designated after the similarity to other PAS proteins: PAS-core, N-terminal connector, $\beta$-scaffold and helical connector (Pellequer et al., 1998) (Figure 1.5). Three relatively long $\beta$-strands $\left(\beta_{4}, \beta_{5}, \beta_{6}\right)$ together with their connecting loops merge in the $\beta$-scaffold. Another three relatively short $\beta$-strands $\left(\beta_{1}, \beta_{2}, \beta_{3}\right)$ together with the $\mathrm{N}$ terminal half of the chromophore binding loop and short $\alpha$-helices $\left(\alpha_{3}, \alpha_{4}\right)$ make the PAS-core. The helical connector is composed of the relatively long $\alpha_{5}$-helix and the $\mathrm{C}$-terminal half of the chromophore binding loop. The short $\alpha$ helices $\left(\alpha_{1}, \alpha_{2}\right)$ and loops form the N-terminal cap. In the resting state the chromophore acid is in the deprotonated state and in an all-trans conformation (Baca et al., 1994; Kort et al., 1996). Tyr42, Thr50 and Glu46 form a hydrogen bond network and stabilize the buried negative charge on the chromophore (Borgstahl et al., 1995).

The crucial property of PYP is that, upon absorption of a blue photon, it enters into a photocycle with several metastable intermediates and the final recovery of the resting state. The photocycle is usually divided into three parts (Figure 1.6). I) The primary photophysical/photochemical events. Light absorption generates the electronically excited state of the chromophore, where a trans/cis isomerisation at the $\mathrm{C}_{7}-\mathrm{C}_{8}$ double bond becomes possible before the transition from the excited state back to the ground state. The

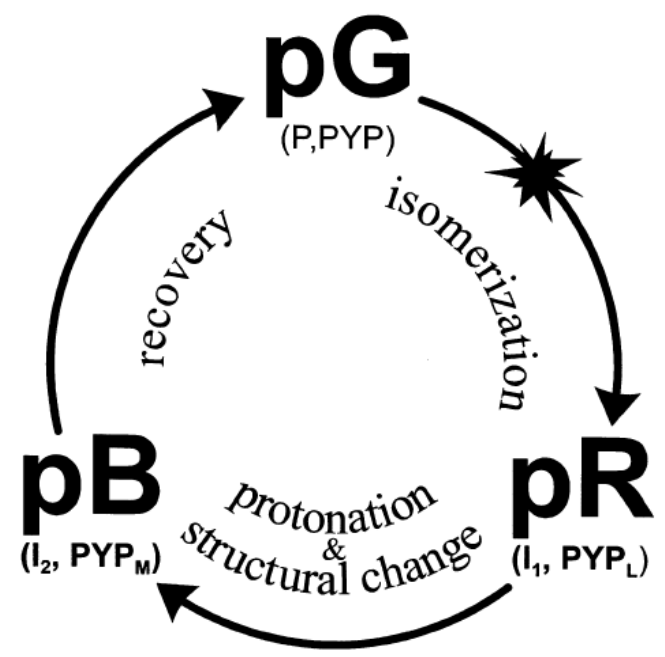

Figure 1.6 Key intermediates and events during the photocycle of photoactive yellow protein (from Hellingwerf et al. (2003). initial isomerization is followed by the rearrangement of hydrogen bonds and amino acids around the chromophore. Within a few nanoseconds and via a number of shortlived intermediates (Ujj et al., 1998; Gensch et al., 2002) the generated cis state relaxes into the first metastable intermediate $\mathrm{pR}_{1}$, with a red shifted absorption spectrum. Another red shifted intermediate, $\mathrm{pR}_{2}$, with only a slightly different absorption spectrum has been reported to form in microseconds (Hendriks et al., 2003). II) Protonation of the p-coumaric acid chromophore. Within microseconds, the chromophore accepts a proton via intramolecular proton transfer from the Glu46 residue, and a blue shifted $\mathrm{pB}_{1}$ 
intermediate is formed. Subsequently, a large conformation change occurs leading to the formation of the signalling state $\mathrm{pB}_{2}$. FTIR (Xie et al., 1996; Xie et al., 2001; Harigai et al., 2003), circular dichroism (Harigai et al., 2003) and NMR (Rubinstenn et al., 1998; Bernard et al., 2005) studies show the decrease of helical content in the $\mathrm{pB}_{2}$ intermediate, and the increase of the protein structural disorder at the N-terminal part. The structure for the $\mathrm{pB}_{2}$ state of the PYP mutant lacking $25 \mathrm{~N}$-terminal amino acids was resolved by NMR (Bernard et al., 2005). It shows that while $\beta$-sheets are relatively stable, all $\alpha$ helices are unfolded in this intermediate. III) The resting state (pG) recovery. To return to the resting state, deprotonation of the p-coumaric acid has to occur and the chromophore has to isomerize back to the trans configuration. The protein also has to refold. Currently, deprotonation of the chromophore is accepted as the first step of the recovery, facilitating protein refolding and chromophore reisomerization (Sergi et al., 2001). The exact mechanism of the recovery is still unclear, but studies on mutant proteins have identified several amino acids, whose replacement greatly modulates the recovery rates (Devanathan et al., 1998). Molecular dynamics (MD) simulations propose that helix refolding can be a bottleneck of the process (Vreede et al., 2008). Besides the above designation of intermediates as $\mathrm{pG} \rightarrow \mathrm{pR} \rightarrow \mathrm{pB} \rightarrow \mathrm{pG}$ (Xie et al., 1996; Chen et al., 2003), other abbreviations, such as $\mathrm{P} \rightarrow \mathrm{I}_{1} \rightarrow \mathrm{I}_{2} \rightarrow \mathrm{P}$ (Meyer et al., 1989; Joshi et al., 2006), and PYP $\rightarrow \mathrm{PYP}_{\mathrm{L}} \rightarrow \mathrm{PYP}_{\mathrm{M}} \rightarrow \mathrm{PYP}$ (Imamoto et al., 1996) are widely used in the literature.

The variability of the cycle with $\mathrm{pH}$ (Genick et al., 1997; Hendriks and Hellingwerf, 2009), ionic strength (Hoersch et al., 2007), viscosity (Meyer et al., 1989) and composition of the buffer (Shimizu et al., 2002) cause additional problems in comparison and analysis of results. The number of PYP photocycle schemes introduced (Hendriks et al., 2003; Ihee et al., 2005; Borucki et al., 2006; Hendriks and Hellingwerf, 2009) shows the non-triviality of the task. The proposed schemes differ in the number of intermediates at different $\mathrm{pH}$ values and in the reversibility or irreversibility of transitions between them. PYP is interesting primarily as a model to study signal transduction within proteins. The signal during the signaling state formation is transferred from the chromophore (the "receptor site") to the N-terminal cap over a distance of about $20 \AA$. To explain this rather long distance signal propagation a number of hypotheses were proposed. In the "protein quake" model (Xie et al., 1996; Xie et al., 
2001), the global structural change is triggered by the chromophore protonation, which results in the appearance of two (opposite) charges in the hydrophobic inside of the protein, generating an unstable arrangement. In the model of hydrophobic collapse (Cusanovich and Meyer, 2003), the chromophore pocket collapses when the isomerized chromophore moves away from its cavity. This leads to the weakening of the interaction between the $\mathrm{N}$-terminal cap and the central $\beta$-sheet, resulting in the exposure of the hydrophobic chromophore binding site which is located in between the $\mathrm{N}$-cap and the $\beta$ sheet. The helix capping model (Rajagopal et al., 2005) proposes the signal propagation via the breakage of the hydrogen bond between Glu46 and Tyr42. This is then followed by the small displacement of the $\beta$-helix. Further studies of the mechanistic details and kinetics of the photocycle under various experimental conditions are required to fully understand the operation of PYP as a photosensor signaling protein.

\subsection{The Hofmeister series of ions}

Non-specific ionic effects were discovered by Franz Hofmeister while studying the influence of ions on protein solubility more than a hundred years ago (Kunz et al., 2004), and have been named after their first investigator. Anions generally have stronger ability to precipitate proteins from solution than cations. The anions are ordered by their strength in the following row (Zhang and Cremer, 2006):

$$
\mathrm{F}^{-}>\mathrm{SO}_{4}{ }^{2-}>\mathrm{HPO}_{4}{ }^{2-}>\text { acetate }>\mathrm{Cl}^{-}>\mathrm{NO}_{3}{ }^{-}>\mathrm{Br}^{-}>\mathrm{ClO}_{3}{ }^{-}>\mathrm{I}^{-}>\mathrm{ClO}_{4}{ }^{-}>\mathrm{SCN}^{-}
$$

Later on, the Hofmeister effect (HE) was associated with the influence of an anion on the water structure. Early members of the above row, up to chloride, are called kosmotropes because they stabilise the structure of proteins, causing their precipitation or "salting out", while the later members are denoted as chaotropes and induce the opposite, "salting-in" behaviour. The chloride ion can be considered "Hofmeister neutral". The effect is not limited to proteins and many biological processes are influenced by ions in a way that follows the Hofmeister series (Nostro et al., 2006). Despite its importance and the active interest and attention paid to it, the exact mechanism of HE has long remained a matter of debate and is still not quite clear (Collins et al., 1985; Cacace et al., 1997; Zhang and Cremer, 2006; Parsons et al., 2011; Nostro and Ninham, 2012). Recently, a new theoretical foundation for HE has been developed, employing the salt dependence of protein-water interfacial tension as the 
Introduction

fundamental parameter describing the phenomenology of HE (Dér et al., 2007; Dér, 2008). Also, direct connections among conformational fluctuations, interfacial tension and protein structural stability have been shown, allowing the microscopic interpretation of HE based on these relations (Neagu et al., 2001; Neagu et al., 2001). According to Dér et al. (2007), for transitions, where large scale water-exposed surface area changes of macromolecules occur, HEs will change the transition rates and equilibrium constants. An important methodological implication of these results concerns the use of $\mathrm{HE}$ in studying both particular and general problems of protein folding and conformational dynamics. 


\section{Aims of the study}

Although almost 50 years have passed since the discovery of electron tunneling in biological objects by Chance and DeVault (DeVault and Chance, 1966), biological electron transfer remains an area of great interest for researchers. A number of theories have been proposed to explain the role of the protein medium in the electron transfer, and the collection of new experimental data may allow their refinement, and a better understanding of the process. Studies of electron transfer reactions in the redox-active enzymes provide crucial information for understanding the mechanism of their function.

The introduction of TUPS by Kotlyar et al. (1997a) provided an easily accessible, flexible covalent photoactive redox label with the promise of the possibility of measuring electron transfer processes both in the reductive and in the oxidative direction in non-photosynthetic systems. TUPS is a viable alternative to the widely used ruthenium complexes in the field due to its favourable properties: its long lived triplet excited state, its low redox potential and last, but not least, the relatively easy chemistry of its production from the IPTS precursor and of its attachment to either lysine or cysteine residues. The latter is especially advantageous in proteins without surface accessible natural cysteines because single cysteines introduced by site directed mutagenesis allow the desired positioning of the label while avoiding complications by multiple labelling.

After several publications by the inventors on the applicability of TUPS to induce protein reduction, our aim was to further study the photochemistry of TUPS in solution and investigate the possibility of using it in photoinduced protein oxidation. The natural choice for studies of the latter was mitochondrial cytochrome $c$, a simple, well characterized protein with a single heme as its redox center. Wild type cytochrome $c$ is commercially available, but its heterologous expression in E. coli and the production of its site directed mutants was achieved earlier in our laboratory. It was also our aim in these studies to see how the electron transfer kinetics depend on the donor-acceptor distance, the packing density of the protein and on putative electron transfer pathways. After interesting and unexpected complications during the experimental phase of this work we looked into the role of the flexibility and mobility of the TUPS label with molecular dynamics calculations. 
Protein dynamics is an omnipresent phenomenon which, in many cases, is strongly coupled to function. Kinetic absorption spectroscopy - the technique available in our laboratory - is a useful tool to study phenomena related to protein dynamics if the processes can be initiated by short laser pulses and followed using the absorption changes of chromophores. One of the best systems for such studies is photoactive yellow protein, with its p-coumaric acid chromophore. This protein is a robust, strongly coloured molecule which serves as a prototype for signal transduction processes. Three distinct processes take place after its photoexcitation: the isomerization of the chromophore, the internal proton transfer from the E46 donor to the chromophore and a major conformational change to the signalling state, which involves partial unfolding of the protein. These properties make PYP an excellent object to study experimentally the $\mathrm{HE}$ on the stability and reaction kinetics of proteins. In the second part of our work we were aiming at demonstrating the effective use of $\mathrm{HE}$ as a tool for the identification of crucial steps of protein function, involving major conformational changes.

In summary, the aims of the study were:

- To investigate in detail the photochemistry and photoinduced electron transfer processes of TUPS in solution, in order to better characterize it as a photoinduced reductant/oxidant.

- To investigate the oxidative properties of TUPS triplet, and its application in photoinduced protein oxidation.

- To study the directional dependence of the electron transfer rate from the heme of cytochrome $c$ to various positions on the surface of the protein, and the changes in the electron transfer rate between TUPS and the heme of cytochrome $c$ upon distance change by modification of the label linker.

- To determine the absorption spectra and the time-dependent concentrations of the PYP photocycle intermediates at close-to-physiological conditions (moderatly alkaline $\mathrm{pH}$, high salt concentration).

- To obtain a sufficiently detailed reaction (photocycle) scheme which adequately describes the PYP photocycle under these conditions and to calculate the molecular rate constants connecting the intermediates, as well as their 
Aims of the study

dependence on Hofmeister salts, by the global fit of the kinetic absorption data.

- Thereby, to demonstrate the efficient use of HE as a tool for the identification of crucial steps of protein function, involving major conformational changes. 


\section{Materials and methods}

\subsection{Reagents}

Horse heart cytochrome $c$, glucose oxidase and catalase were purchased from Sigma-Aldrich (Hungary), IPTS from Lambda Fluorescence Technology (Graz, Austria) or Sigma-Aldrich (Hungary). Cytochrome $c$ oxidase was isolated from bovine heart submitochondrial particles (King, 1967) using the method of Yonetani (1967) with minor modifications. Aliquots of the purified enzyme were split in portions, frozen in liquid nitrogen and stored at $-80^{\circ} \mathrm{C}$. PYP was a kind gift of Dr. Terry Meyer (University of Arizona, Tucson). All chemicals were of analytical grade form Sigma-Aldrich or Reanal and were used as received without further purification. The concentration of proteins was estimated spectrophotometrically using molar extinction coefficients of $29,500\left(\mathrm{M}^{-1} \times \mathrm{cm}^{-1}\right)$ at $550 \mathrm{~nm}$ for reduced cytochrome $c$ (Margoliash and Lustgarten, 1962), 3,980 $\left(\mathrm{M}^{-1} \times \mathrm{cm}^{-1}\right)$ at $604 \mathrm{~nm}$ for reduced cytochrome $c$ oxidase (Yoshikawa et al., $1977)$ and $48,000\left(\mathrm{M}^{-1} \times \mathrm{cm}^{-1}\right)$ at $446 \mathrm{~nm}$ for PYP (Meyer, 1985).

\subsection{Recombinant cytochrome c expression and purification}

Recombinant mutant horse cytochromes $c$ were expressed in BL21 E. coli strain from pBAD24 plasmid. The plasmid design, the expression and purification of recombinant mutant $c$ cytochromes were carried out by Dr. Katalin Tenger as described in Tenger et al., $(2005,2007)$.

\subsection{Preparation of TUPS-lysine and TUPS-cystamine derivatives}

TUPS-lysine adduct preparation and purification was done by the group of Alexander Kotlyar and described in Kotlyar et al. (1997a). In brief, 5 mM lysine was incubated with $1 \mathrm{mM}$ of IPTS in $50 \mathrm{mM}$ HEPES/KOH buffer $(\mathrm{pH}=8.5)$ for 15 hours at $38^{\circ} \mathrm{C}$. The product was purified on a LiChrosorb RP-18, 50-A reverse-phase HPLC column $(250 \times 4.6 \mathrm{~mm}$, from Knalier, Germany). The derivative was eluted by a linear gradient of acetonitrile from $4 \%$ to $50 \%(0.1 \%$ TFA) at a flow rate of $0.7 \mathrm{ml} / \mathrm{min}$. The thiol specific TUPS-cystamine derivative was used for labelling mutated $c$ cytochromes on introduced cysteine residues prepared by a modified method of Kotlyar et al. (2000). $20 \mathrm{mM}$ of IPTS was incubated with $10 \mathrm{mM}$ of cystamine at $\mathrm{pH}=9$, in the presence of 
$300 \mathrm{mM} \mathrm{KCl}$ for approximately 6 hours at room temperature. To block non-reacted IPTS, lysine was added (final concentration $200 \mathrm{mM}$ ), and the incubation continued until free IPTS became spectrally undetectable in solution.

\subsection{Cytochrome c labelling}

Cytochrome $c$ was labelled with TUPS at Lys86, Lys8 and Lys39 as described in Kotlyar et al. (1997b). To label cysteines introduced by site directed mutagenesis at the same positions, the mutant cytochrome $c$ was treated with $5 \mathrm{mM}$ dithiothreitol for 1 hour to break possible protein dimers formed via disulphide bond between the engineered cysteines. Excess of dithiothreitol was removed by gel filtration on a PD-10 column, equilibrated with $150 \mathrm{mM}$ HEPES $(\mathrm{pH}=8.5)$. Cytochrome $c$ was incubated with 4-fold excess of the thiol specific TUPS adduct in $150 \mathrm{mM}$ HEPES ( $\mathrm{pH}=8.5), 0.2 \mathrm{M}$ $\mathrm{KCl}$ and $100 \mathrm{mM}$ lysine for $4 \mathrm{~h}$ in dark. The product was purified from unbound TUPScystamine and excess of salt by passing through a PD-10 column equilibrated with 10 $\mathrm{mM}$ HEPES $(\mathrm{pH}=7.5)$. To separate labelled and unlabelled fractions the protein was purified on a CM-sephadex column (10 $\mathrm{mM}$ sodium phosphate buffer, $\mathrm{pH}=8.5$, linear $\mathrm{NaCl}$ gradient $0-0.5 \mathrm{M}$ ) and concentrated by centrifugation, using Amicon centrifugal filter units. It was finally split into aliquots, frozen in liquid nitrogen and stored at $-80^{\circ} \mathrm{C}$.

\subsection{UV-VIS stationary and transient spectroscopy measurements}

An Unicam UV4 spectrophotometer was used to measure stationary UV-VIS spectra. Kinetic flash spectroscopy was carried out on a homemade setup sketched in Figure 3.1. The cuvette with the sample (15) was placed into a thermostatable sample holder (14). The third harmonic frequency of a Nd:Yag laser $(5 \mathrm{~ns}, 20 \mathrm{~mJ} / \mathrm{cm}$, Surelite 1-10, Continuum Inc.) (19) was used for excitation of the TUPS dye. The Thorlabs NB1-J08 Nd: YAG mirrors (11) were used to direct the excitation beam into the thermostated sample holder. Optionally quartz lenses (13) could be placed in the beam path to focus the laser beam. A continuous white measuring light (18) from a $35 \mathrm{~W}$ Hamamatsu high pressure Xenon lamp (17) (Hamamatsu City, Japan) focused by the spherical mirror (8) passed through the sample holder and was focused by the spherical mirror on the slit of a HR-320 monochromator (ISA Jobin YVON) with a 100 groove/mm density grating (10). The spectrum was dispersed on an Andor iStar ICCD 
DH720-18U-03-9CC detector (7), connected to a PC computer (1) via a CCI-010 PCI controller card (2). During TUPS photochemistry experiments a Princeton Instruments diode array was used instead of the ICCD detector. Wavelength calibration was performed using interference filters. To avoid the formation of photostationary states, heating effects and other artefacts possibly caused by the measuring light, the beam was chopped by a digital shutter (16) (Uniblitz, Vincent Assoc., Ronchester, NY). All measurements were controlled using scripts written in Andor Basic (Andor iStar software version 4.2.0.2, Andor Technology, Dublin). This setup allowed us to measure spectra in the 290-750 $\mathrm{nm}$ range with submicrosecond resolution. Difference spectra were collected at several delays per decade relative to the actinic laser pulse. For each

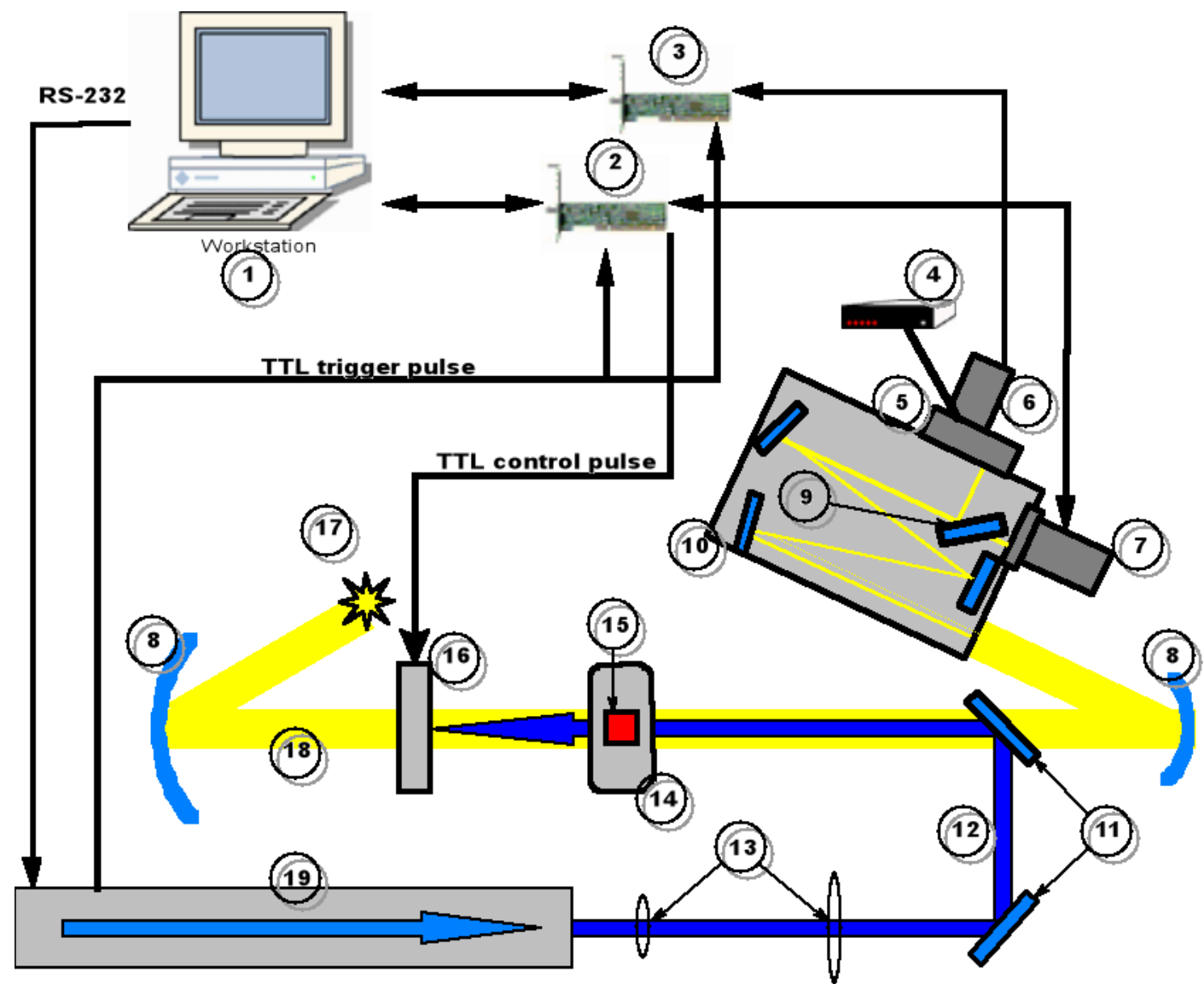

Figure 3.1 Schematic representation of the setup for transient spectroscopy measurements. 1-IBM PC computer; 2-PCI controller card; 3-high speed digital oscilloscope card (NI5102); 4-photomultiplier power supply; 5-photomultiplier; 6amplifier; 7-CCD detector (DH720-19U-C3-9C); 8-spherical mirrors; 9-switching mirror; 10-spectrograph/monochromator (Jobin-Yvon HR-320); 11-laser reflecting mirrors; 12-laser beam; 13-focusing lenses; 14-sample holder; 15-sample; 16-digital shutter (Vincent); 17-high pressure xenon lamp ;18-measuring light beam; 19-Nd-YAG laser (Continuum Surelite I). 
time delay 10 to 50 scans were averaged. The removable mirror (9), allowed to project the spectrum through a lateral slit onto a photomultiplier (6) (Hamamatsu City, Japan). Selecting the wavelength of interest with the slit allowed us to measure single wavelength kinetic traces, which were amplified by a homemade amplifier and digitized at a $20 \mathrm{MHz}$ sampling rate (National Instruments NI5102 oscilloscope card, Austin, TX). The "FIXED SYNC OUT" output of the Surelite laser was used to trigger the single wavelength acquisition. Reduction and oxidation of cytochrome $c$ was measured by the weighted difference of 550 and $562 \mathrm{~nm}$ kinetic traces.

All measurements on TUPS and on TUPS labelled cytochromes $c$ were done in 10 $\mathrm{mM}$ HEPES buffer, $\mathrm{pH}=7.0$ or 7.5 , at $20^{\circ} \mathrm{C}$. TUPS-cytochrome $c$ concentration ranged from 10 to $20 \mu \mathrm{M}$. Reduced or partially reduced (as stored) cytochrome $c$ was oxidized by addition of substoichiometric (few $\mathrm{nM}$ ) amounts of bovine cytochrome $c$ oxidase. Oxygen removal was achieved by the glucose oxidase/catalase system $(20 \mathrm{mM}$ D-glucose, glucose oxidase $0.1 \mathrm{mg} / \mathrm{ml}$, catalase $0.01 \mathrm{mg} / \mathrm{ml}$ ). The TUPS triplet base spectrum was measured on a photoexcited TUPS-alanine solution, under oxygen-free conditions and at a low enough TUPS concentration to avoid electron self-exchange.

The PYP photocycle was measured in $10 \mathrm{mM}$ TRIS buffer, $\mathrm{pH}=8.2$, in the presence of $0.66 \mathrm{M}$ of $\mathrm{NaF}, \mathrm{NaCl}, \mathrm{NaNO}_{3}, \mathrm{NaI}$ or $\mathrm{NaClO}_{4}$. "Low salt" experiments were done in $50 \mathrm{mM} \mathrm{NaCl}$. The optical density of the sample was in the range of 0.60.7. The sample was exited at $450 \mathrm{~nm}\left(5 \mathrm{~ns}, 5 \mathrm{~mJ} / \mathrm{cm}^{2}\right)$ using an optical parametric oscillator [OPO] (Surelite, Continuum Inc.) in combination with the Nd-Yag laser. The dichroic mirrors M1 and M2 in this case were replaced by glass prisms.

\subsection{Molecular dynamics and electron transfer parameter and pathway calculations}

The protein database (PDB) entry 1HRC (Bushnell et al., 1990) was used for the construction of the models for TUPS labelled cytochromes $c$. The MD calculations were carried out with the SYBYL 7.0 software (Tripos, Inc., St. Louis, MO) on an Origin2000 workstation (Silicon Graphics, Inc., Mountain View, CA). For the MD simulations, the Tripos force field (Clark et al., 1989) and a dielectric constant value of 80 were applied, and the cutoff was set to $30 \AA$ for non bonding interactions. MD calculations were performed by Dr. Balázs Leitgeb. Optimal electron transfer pathways 
and electron transfer parameters were calculated by the HARLEM program (Kurnikov, 2001) using the PDB output of the molecular dynamics calculations. In addition to SYBYL, MOLMOL (Koradi et al., 1996) and PYMOL (DeLano and Scientific, 2002) packages were used for visualization of the MD results.

\subsection{Mathematical data analysis}

Statistical analysis of data, curve fitting and mathematical modeling were done in the MATLAB scripting language (Mathworks ${ }^{\mathrm{TM}}$ ). The distribution of rate constants and the set of discrete rate constants were determined from the single wavelength kinetic absorption traces by the maximum-entropy/nonlinear-least-squares method using the program MemExp-3.0 (Steinbach et al., 2002).

Consecutive difference spectra were collected as columns of a data matrix $\mathbf{D}_{\mathbf{m} \times \mathbf{n}}$, where $n$ denotes the number of consecutive spectra and $m$ stands for the number of wavelength points. According to the Beer-Lambert law the elements of the data matrix are the sum of the products of the difference spectra of the pure intermediates and their time-dependent concentrations:

$$
D\left(\lambda_{i}, t_{j}\right)=\sum_{p=1}^{k} \Delta \epsilon_{p}\left(\lambda_{i}\right) \times c_{p}\left(t_{j}\right)
$$

Here $\mathrm{k}-$ stands for the number of intermediates. The matrix form of the expression above is:

$$
D=\Delta \epsilon c^{T}
$$

Singular value decomposition (SVD) was used to estimate the rank of the spectrotemporal data matrices, and for efficient noise filtering. SVD treatment of a matrix is a factorization into three new matrices with special properties:

$$
D=U S V^{T}
$$

Matrices $\mathbf{U}(\mathrm{m} \times \mathrm{n})$ and $\mathbf{V}(\mathrm{n} \times \mathrm{n})$ consist of the orthonormal spectral eigenvectors and the orthonormal kinetic eigenvectors, respectively, and the $\mathbf{S}(\mathrm{n} \times \mathrm{n})$ diagonal matrix contains the singular values. For noisy data the effective rank (r) can be estimated by a combination of criteria. First, $\sum_{\mathrm{i}=\mathrm{r}+1}^{\mathrm{n}} \mathrm{S}_{\mathrm{ii}}{ }^{2}$ should be less than the average noise of $\mathbf{D}$, estimated as $\mathrm{n} \times \mathrm{m} \times \sigma^{2}$, where $\sigma^{2}$ is the average variance of the elements of $\mathbf{D}$. Second, the autocorrelations of the first $r$ columns of $\mathbf{U}$ and $\mathbf{V}$ should be high enough, which distinguishes them from those eigenvectors carrying only noise. Experimental data often 
contain noise (or error) with non-normal distribution, which may result in pairs of eigenvectors beyond $\mathrm{r}$ (as determined by the noise criterion) with relatively high autocorrelation. In such cases the rotation algorithm of Henry and Hofrichter (2010) is a recommended tool to "pull forward" these low amplitude signals with high autocorrelation.

In our electron transfer studies in TUPS or TUPS-cytochrome $c$ containing samples the spectra of the different transient forms could be measured by either stationary or time-resolved experiments. In such cases the kinetics of these forms can be obtained by a nonlinear least-squares fit of the data matrix (preferably after noise reduction) with the $\Delta \varepsilon$ matrix. In the PYP photocycle studies, on the other hand, both the difference spectra and the concentrations on the right-hand side of equation 8 are unknown. The following procedure was used for the analysis of the spectrotemporal matrices measured on PYP samples. With the assumption that the transitions between the intermediates are first order, the concentration matrix can be defined by a sum of time-dependent exponentials:

$$
c^{T}=P_{k \times e} E_{n \times e}^{T}, \text { with } E_{i, j}=\exp \left(-\lambda_{j} t_{i}\right)
$$

Here the number of exponentials, represented by subscript e, can be greater than the effective rank $r$ of matrix $\mathbf{D}$, or in other words, greater than the number of spectrally distinct intermediates. Combining equations (8) and (10) the definition of exponential amplitude spectra or B spectra is derived:

$$
D=B_{m \times e} E^{T}, \text { where } B=\Delta \epsilon P
$$

Combining the last equation with equation 9:

$$
B E^{T}=U S V^{T}
$$

and bearing in mind the orthonormality of $\mathbf{U}$ columns, after multiplication of both sides by the transform of $\mathbf{U}$ :

$$
U^{T} B E^{T} \equiv Q_{r \times e} E^{T}=S V^{T}
$$

Hence, $\left(\mathbf{S V}^{\mathbf{T}}\right)$ can also be resolved into the linear combination of the same exponentials. Thus, from the simultaneous fit of the weighted kinetic vectors of SVD to sums of exponentials the phenomenological (apparent) rate coefficients, $\lambda_{\mathrm{j}}$ and their amplitudes, $\mathbf{Q}$ can be obtained. The exponential amplitude spectra B are easily calculated using the fact that the exponential functions with different rate coefficients are linearly 
Materials and methods

independent:

$$
B E^{T}=U Q E^{T} \text {, therefore } B=U Q
$$

As in our experiments the gated CCD detector provides more wavelength channels than time points, and the latter is still more than the number of fitted exponentials, the magnitude of various indices can be arranged in the following row: $\mathrm{m}$ $>\mathrm{n}>\mathrm{e} \geq \mathrm{k} \geq \mathrm{r}$.

After SVD and the global multiexponential fit to the weighted kinetic eigenvectors, further analysis was performed in two stages, producing the absorption spectra and time-dependent concentrations of the photocycle intermediates, along with the microscopic rate coefficients of the transitions between them. First, the method of Joshi et al. (2006), modified as described below, was used to obtain the initial guess for the photocycling fraction (photoproduct yield) and for the spectra of the intermediates. These were used in the second stage, involving global spectrotemporal model fitting of the data, with the photocycling fraction, the intermediate spectra and the rate coefficients of the photocycle scheme as variable parameters.

New matrices $\mathbf{B}^{\sim}$ and $\mathbf{P}^{\sim}$ were derived by adding the columns of $\mathbf{B}$ and $\mathbf{P}$ in the following way:

$$
B_{p}^{\sim}=B_{p}+B_{p+1}+\ldots+B_{e} \wedge P_{p}^{\sim}=P_{p}+P_{p+1}+\ldots+P_{e}(p=1,2, \ldots, e)
$$

so that according to the left part of equation 11

$$
B^{\sim}=\Delta \in P^{\sim}
$$

The columns of the new $\mathbf{B}^{\sim}$ matrix are the extrapolated difference spectra which correspond to the spectra of the components (pure intermediates or intermediate mixtures) of the consecutive exponential transitions. The contribution of the intermediates to the extrapolated difference spectra can be found in the corresponding columns of $\mathbf{P}^{\sim}$ or, in other words, the contribution of the columns of matrix $\mathbf{B}^{\sim}$ to the pure intermediate spectra in the columns of the inverse of $\mathbf{P}^{\sim}$. At the time points before recovery to the ground state starts, the sum of the former contributions and, hence, the sum of the columns of $\mathbf{P}^{\sim}$ is constant and equal to the photocycling fraction. Five exponential processes were necessary to fit the kinetic $\mathbf{V}$ vectors of our data taken over a wide time domain, but since the rank $r$ of the parent matrix $\mathbf{B}$ was 3 , the five columns 
of matrix $\mathbf{B}^{\sim}$ were not linearly independent. Hence, for further calculation of the blue shifted $\mathrm{pB}_{2}$ spectrum via target testing, three representative columns of $\mathbf{B}^{\sim}$ were selected, instead of the full matrix as in the original method of Joshi et al. (2006) (see section 4.4.2). Target testing consisted of calculating the coefficients of the negative of the $\mathrm{pG}$ spectrum beyond $430 \mathrm{~nm}$, which is identical to the $\mathrm{pB}_{2}-\mathrm{pG}$ difference spectrum since the $\mathrm{pB}_{2}$ spectrum is expected to be uniformly zero beyond $430 \mathrm{~nm}$, in a linear combination of the truncated $(>430 \mathrm{~nm})$ columns of matrix $\mathbf{B}^{\sim}$. The full $\mathrm{pB}_{2}-\mathrm{pG}$ difference spectrum was thus obtained as the linear combination of the full columns of $\mathbf{B}^{\sim}$ with the same coefficients. These coefficients provided the corresponding, third column of the now 3 by 3 matrix $\left(\mathbf{P}^{\sim}\right)^{-1}$, and enabled the calculation of the photocycling fraction. With the assumption that at "time zero" only the red shifted intermediates contribute to the difference spectrum, their (at this point still identical) spectrum could be calculated by adding the photocycling fraction-normailzed pG spectrum to the first column of $\mathbf{B}^{\sim}$. This is equivalent to setting the first column of the matrix $\mathbf{P}^{\sim}$ to [photocycling fraction, $0,0]$. As it turned out, the target testing treatment to obtain the $\mathrm{pB}_{1}$ spectrum was not possible due to a broad shoulder on its red side (see 4.4.2). Instead, the trial-and-error method of Joshi et al. (2006) was successfully applied to estimate the spectrum of this intermediate (via estimating the elements of the second column of $\mathbf{P}^{\sim}$ ). The criterion was the nonnegativity of the corresponding $\mathrm{pB}_{2}$ absolute spectrum. The three intermediate spectra thus estimated were used as "seed spectra" in the subsequent global spectrotemporal model fit based on equation 8 . The fitted function was a single vector made up of the rearranged spectrotemporal data matrix augmented at the end by the phenomenological rates from the global multiexponential fit. The estimated difference spectra of the intermediates, the rate coefficients of the kinetic model describing the photocycle and the photocycling fraction were the varied parameters. To decrease computation time, the number of spectral fitting parameters and hence the size of the fitted function were decreased via application of a 5 point average along the spectral dimension. In this manner 1409 data points (27 difference spectra, 52 points each plus 5 phenomenological rate coefficients) were fitted by 218 unknown parameters (4 intermediate spectra excluding $\mathrm{pG}_{1}, 52$ points each, 9 rate coefficients of the sequential reversible kinetic scheme and the photocycling fraction). The variability of the spectral parameters during the fit was limited to $10 \%$ of their initial value and the nonnegativity 
constraint was applied to the corresponding absolute spectra of the intermediates, forbidding negative values beyond noise. Using the estimated initial concentration (photocycling fraction) and rate coefficients the kinetics of the intermediates, c, was calculated. Knowing matrix c, the final intermediate spectra were obtained by inversion of equation (8), via multiplication of the full spectral resolution data matrix with the pseudoinverse of $\mathbf{c}^{\mathrm{T}}$. 


\section{Results}

\subsection{Redox photochemistry of TUPS}

Photoexcitation of TUPS-lysine produces the triplet state. Its rather structureless difference spectrum can be seen in Figure 4.1 (top). It decays exponentially with halflife time of approximately half millisecond. The evolution of the TUPS triplet in the presence of the oxidant, $250 \mu \mathrm{M}$ ferricyanide, shows an evident formation of the oxidized radical TUPS ${ }^{+}$, with its diagnostic peak at $450 \mathrm{~nm}$ (Figure 4.1, middle). The bimolecular rate constant of the TUPS*/ferricyanide reaction is in the order of
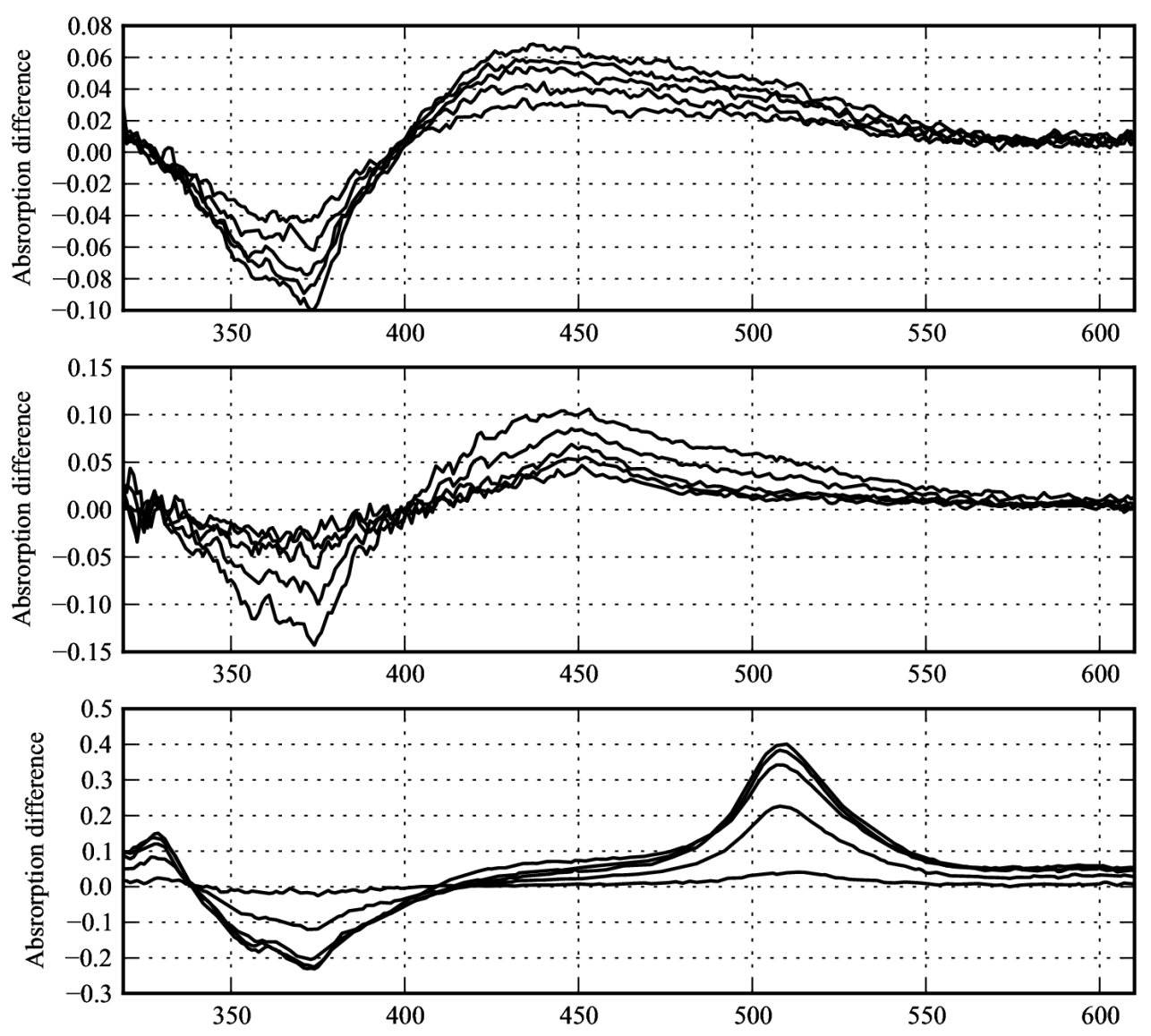

Figure 4.1 Transient spectra of the TUPS triplet formed after excitation of $10 \mu M$ TUPS-lysine (top), after its reaction with ferricyanide $(250 \mu M)$ (middle) and ascorbate (10 mM) (bottom). HEPES $10 \mathrm{mM}, \mathrm{pH}=7.0$, anaerobic conditions. Time delays in the order of signal amplitude decrease: $200 \mathrm{~ns}, 1 \mu \mathrm{s}, 10 \mu \mathrm{s}, 100 \mu \mathrm{s}, 1 \mathrm{~ms}$. Each spectrum is an average of 10 measurements. 


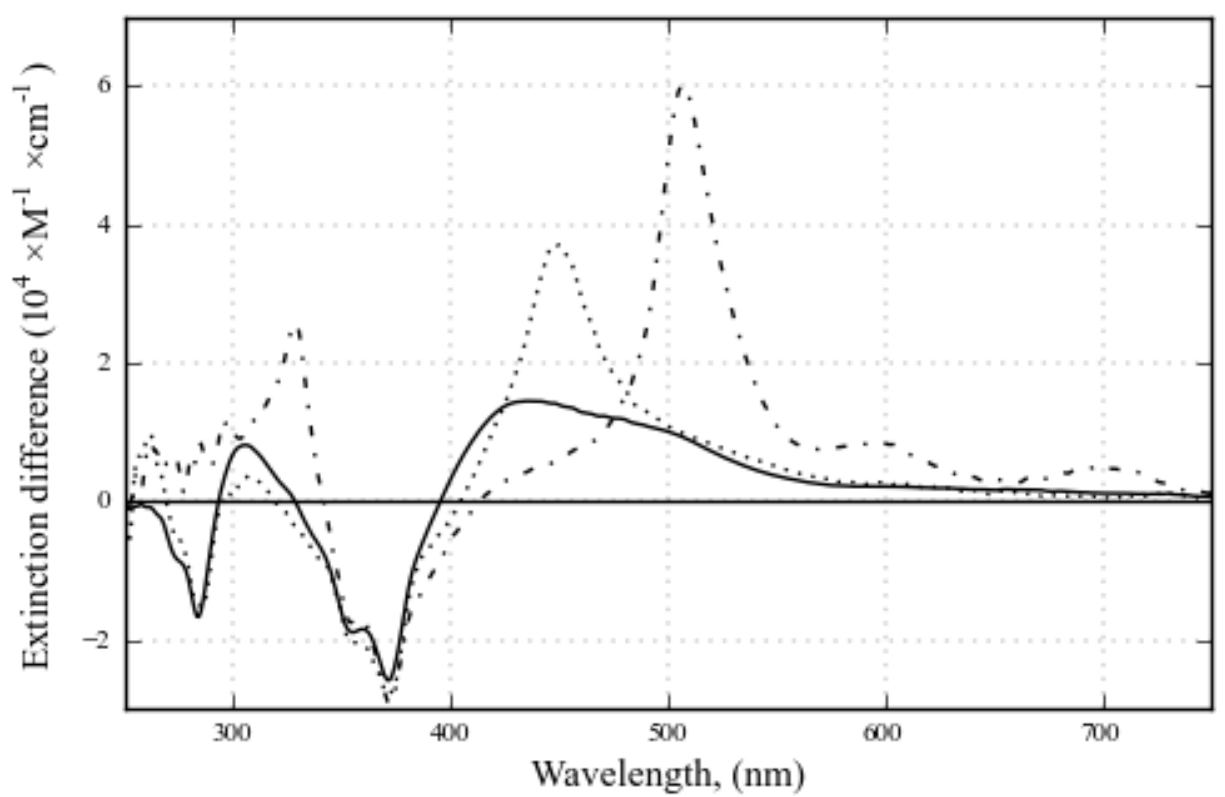

Figure 4.2 Molar extinction difference spectra of the triplet excited state (solidline), and the oxidized (dash-dotted line) and reduced (dotted line) radicals of TUPS.

$10^{9} \mathrm{M}^{-1} \times \mathrm{S}^{-1}$, in accordance with previous work (Kotlyar et al., 1997a). If, however, a reductant is present in the solution $(10 \mathrm{mM}$ ascorbic acid), the reduced radical TUPS-, characterized by a peak at $508 \mathrm{~nm}$, accumulates within $1 \mathrm{~ms}$ after the laser pulse. The differential extinction spectra of the TUPS ${ }^{*}$, TUPS $^{+}$and TUPS- forms relative to TUPS are plotted in Figure 4.2. To estimate them, signals were measured at time delays and conditions where only one form is present. Namely, $1 \mu$ s for TUPS ${ }^{*}, 100 \mu$ s in the presence of $250 \mu \mathrm{M}$ ferricyanide for $\mathrm{TUPS}^{+}$and $1 \mathrm{~ms}$ in the presence of $10 \mathrm{mM}$ ascorbate for TUPS- To improve the signal to noise ratio, the number of scans averaged and the acquisition time were increased. The absolute spectrum of TUPS ground state was calculated from a measured spectrum of $60 \mu \mathrm{M}$ TUPS solution (Figure 4.3). The negative parts of the difference spectra in the $350-370 \mathrm{~nm}$ region are due to bleaching of the ground state of TUPS. By adding to the difference spectra of the photoproducts the spectrum of TUPS, scaled to minimize its vibrational features in this region, the absolute extinction spectra of all three forms could be calculated (Figure 4.3).

After excitation of a $20 \mu \mathrm{M}$ TUPS-lysine solution in the presence of $1 \mathrm{M} \mathrm{KCl}$, the early triplet formation is followed by the appearance of more complex difference spectra with distinctive peak characteristics for both the oxidized and reduced radicals as can be seen in Figure 4.4. Only the decay of the triplet spectrum is observed in the 
Results

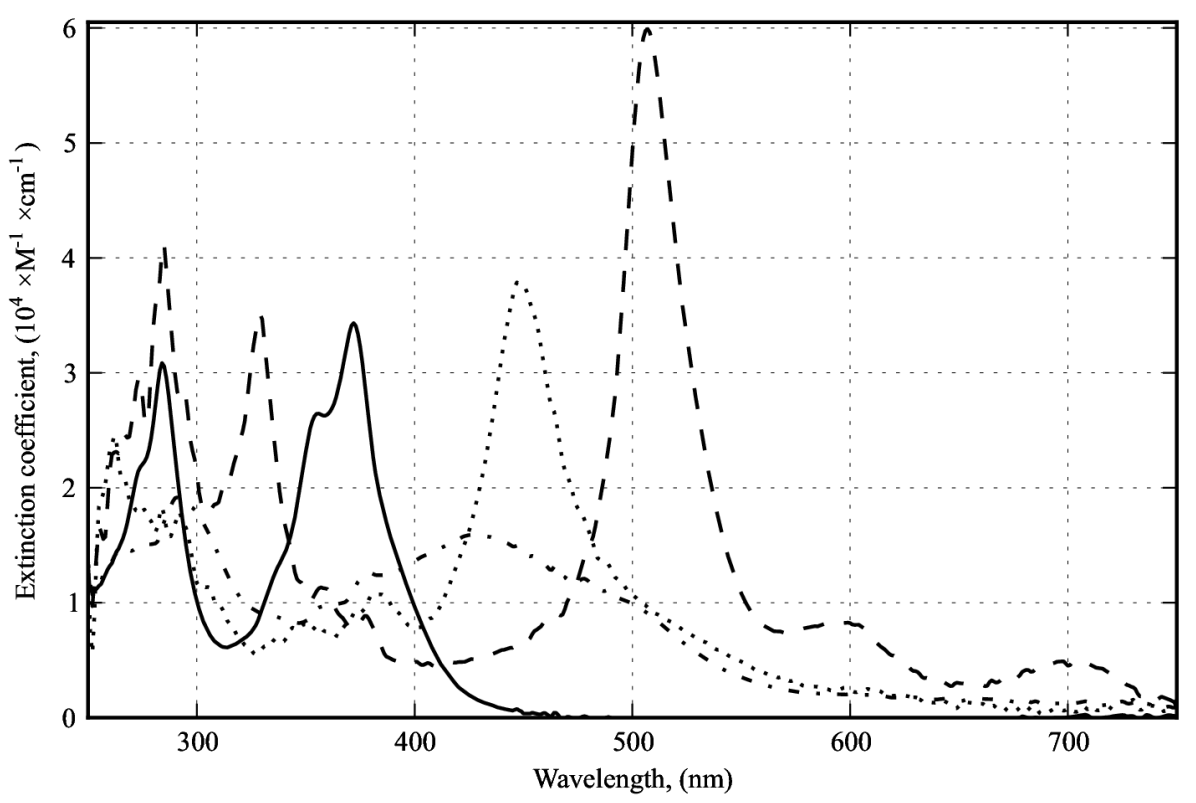

Figure 4.3 Molar extinction absolute spectra of the triplet exited state (dash-dotted line), the oxidized (dotted-line) and reduced (dashed line) radicals of TUPS, as well as the parent TUPS species (solid line).

absence of salt (Figure 4.1, top), which demonstrates that the screening of the three negative charges of TUPS is required for the formation of the radicals.

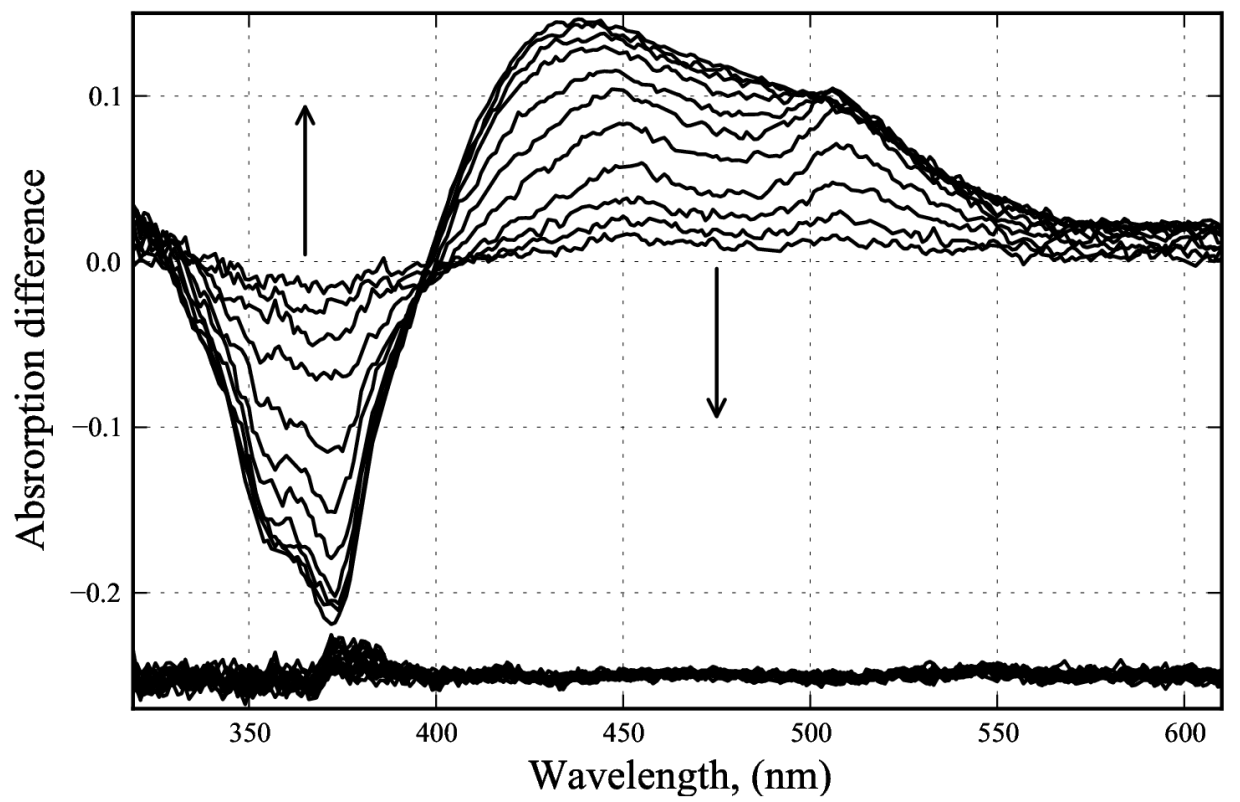

Figure 4.4 Selected time-resolved difference spectra of TUPS-lysine. Delay times after the laser excitation are: 250ns, 3, 7.5, 15, 35, 75, 150, 350, $750 \mu \mathrm{s}, 1.5$ and 3 ms. Arrows indicate the time evolution of the signal. The residuals of the fit by the difference spectra of TUPS ${ }^{+}, T U P S^{-}$and TUPS ${ }^{*}$ are shown in the bottom, offset by -0.25 . 


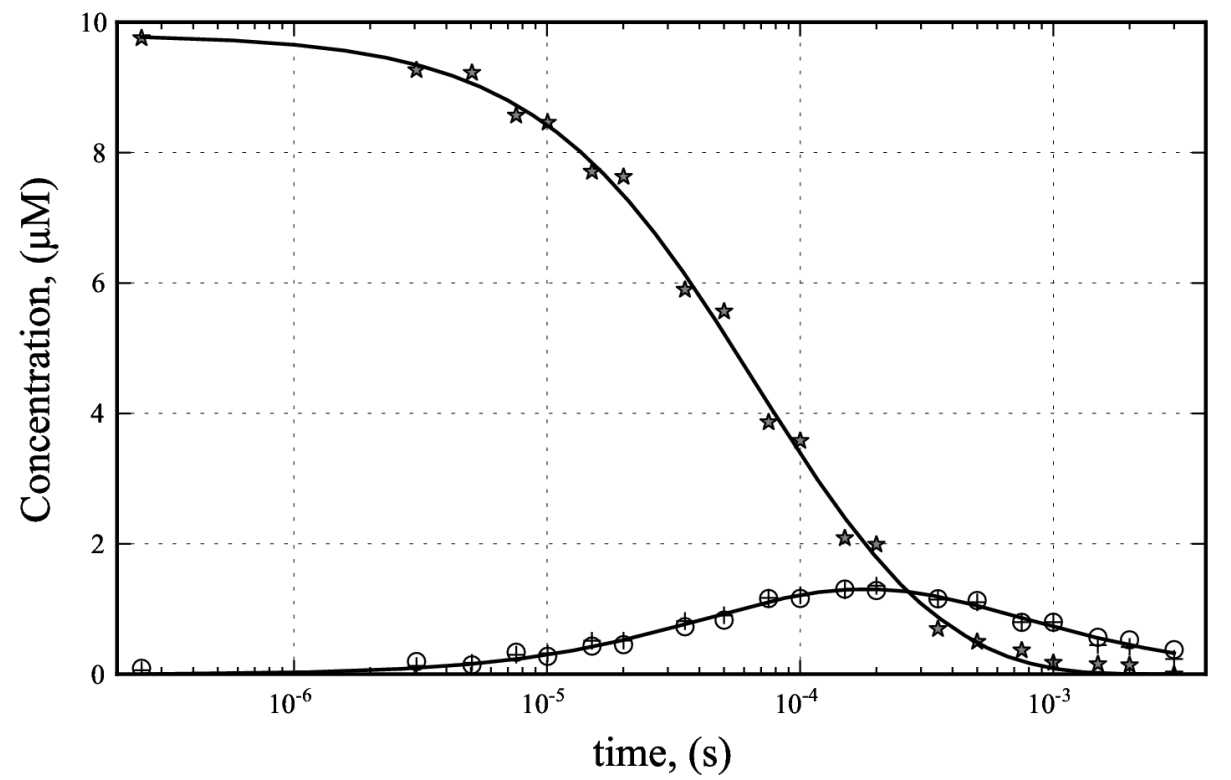

Figure 4.5 Kinetics of the TUPS forms obtained by fitting the entire data matrix represented in Fig. 4.4 using the base spectra in Fig. 4.2 TUPS $^{*}$ - stars; TUPS ${ }^{+}$crosses; TUPS - - circles. Fit of the kinetics by the model described in the text (lines).

The non-negative least-squares-fit of the data-set in Figure 4.4 by the three difference spectra of the various TUPS forms from Figure 4.2 produced the timedependent concentrations of the triplet TUPS ${ }^{*}$, the oxidized radical TUPS $^{+}$and the reduced radical TUPS- (Figure 4.5). Several models were tested in order to fit these kinetic traces. Similarly to the low ionic strength situation, the reaction scheme has to include triplet decay. The overlapping kinetic traces for positive and negative TUPS radicals indicate that radical formation occurs via electron transfer between two triplet molecules and the decay of radicals goes via their recombination. However, this simplest model had failed to reproduce the kinetics of TUPS ${ }^{*}$. An excellent fit was obtained on the basis of the following reaction scheme, which includes the triplet-triplet annihilation in addition to the reactions mentioned before:

$$
\begin{aligned}
& \text { TUPS }^{*} k_{p}-T U P S \\
& T U P S^{*}+T U P S^{*} k_{a}-T U P S+T U P S \\
& T U P S^{*}+T U P S^{*} k_{e}-T U P S^{+}+T_{U P S}^{-} \\
& T_{U P S}^{+}+T_{U P S}^{-} k_{r} \text { TUPS + TUPS }
\end{aligned}
$$

The rate equations corresponding to this scheme are: 
Results

$$
\begin{gathered}
\frac{d\left[\text { TUPS }^{*}\right](t)}{d t}=-k_{p}\left[\text { TUPS }^{*}\right]-\left(k_{a}+k_{e}\right)\left[\text { TUPS }^{*}\right]^{2} \\
\frac{d\left[T U P S^{+}\right](t)}{d t}=k_{e}\left[\text { TUPS }^{*}\right]^{2}-k_{r}\left[\text { TUPS }^{+}\right]^{2} \\
{\left[\text { TUPS }^{+}\right]=\left[\text {TUPS }^{-}\right] \text {and }\left[T_{U P S}^{+}\right](0)=0}
\end{gathered}
$$

These equations were simultaneously solved numerically by varying the initial amount of the TUPS* triplet and the rate constants $\mathrm{k}_{\mathrm{p}}, \mathrm{k}_{\mathrm{a}}, \mathrm{k}_{\mathrm{e}}$ and $\mathrm{k}_{\mathrm{r}}$, until the best fit to the experimentally determined concentrations (Figure 4.5, solid lines) was obtained by a nonlinear least-squares algorithm. The standard deviation of the fit was $\sigma=1.36 \times 10^{-7}$, the calculated initial triplet concentration was $9.78 \pm 0.09 \mu \mathrm{M}$, which is $49 \%$ of the total TUPS concentration. The rate constants obtained from the fit were: $k_{p}=$ $(3.1 \pm 0.7) \times 10^{3} \mathrm{~s}^{-1}, \mathrm{k}_{\mathrm{a}}=(9.7 \pm 1.2) \times 10^{8} \mathrm{M}^{-1} \times \mathrm{s}^{-1}, \mathrm{k}_{\mathrm{e}}=(3.69 \pm 0.08) \times 10^{8} \mathrm{M}^{-1} \times \mathrm{s}^{-1}$ and $\mathrm{k}_{\mathrm{r}}=$ $(8.7 \pm 0.5) \times 10^{8} \mathrm{M}^{-1} \times \mathrm{s}^{-1}$. This model involves several processes. The rate $\mathrm{k}_{\mathrm{p}}$ describes spontaneous triplet decay (by phosphorescence or intersystem crossing), a process which plays relatively little role in the present experiment since the alternative depopulation mechanisms of the triplet excited state are faster. $\mathrm{k}_{\mathrm{a}}$ is the bimolecular rate constant for triplet-triplet annihilation. The process described by $\mathrm{k}_{\mathrm{e}}$ is electron transfer, which results in the positive and negative radicals as measurable distinct entities. Finally, $\mathrm{k}_{\mathrm{r}}$ is the (diffusion limited) rate of charge recombination between the two radicals. None of the elements of the above scheme could be left out without a serious deterioration of the quality of the fit.

\subsection{Electron transfer in singly labelled cytochrome $c$ derivatives}

Electron transfer in the TUPS-ferrocytochrome $c$ system was also investigated using multichannel spectroscopy. Figure 4.6 shows time-resolved difference spectra taken in anaerobiosis after photoexcitation of reduced cytochrome $c$ labelled with TUPS on Lys86. Visual inspection of the earliest difference spectra shows that they are dominated by the initial TUPS triplet formation. The subsequent accumulation of the reduced radical of TUPS (508 $\mathrm{nm}$ peak), and the simultaneous transient oxidation of the cytochrome $c$ heme (depletion peak at $550 \mathrm{~nm}$ ) is observed already in the submicrosecond range. Evaluation of these processes was done by fitting the timeresolved difference spectra using the two base spectra shown in Figure 4.7, the TUPS* TUPS difference spectrum (solid line), and the one-to-one mixture of the difference 
Results

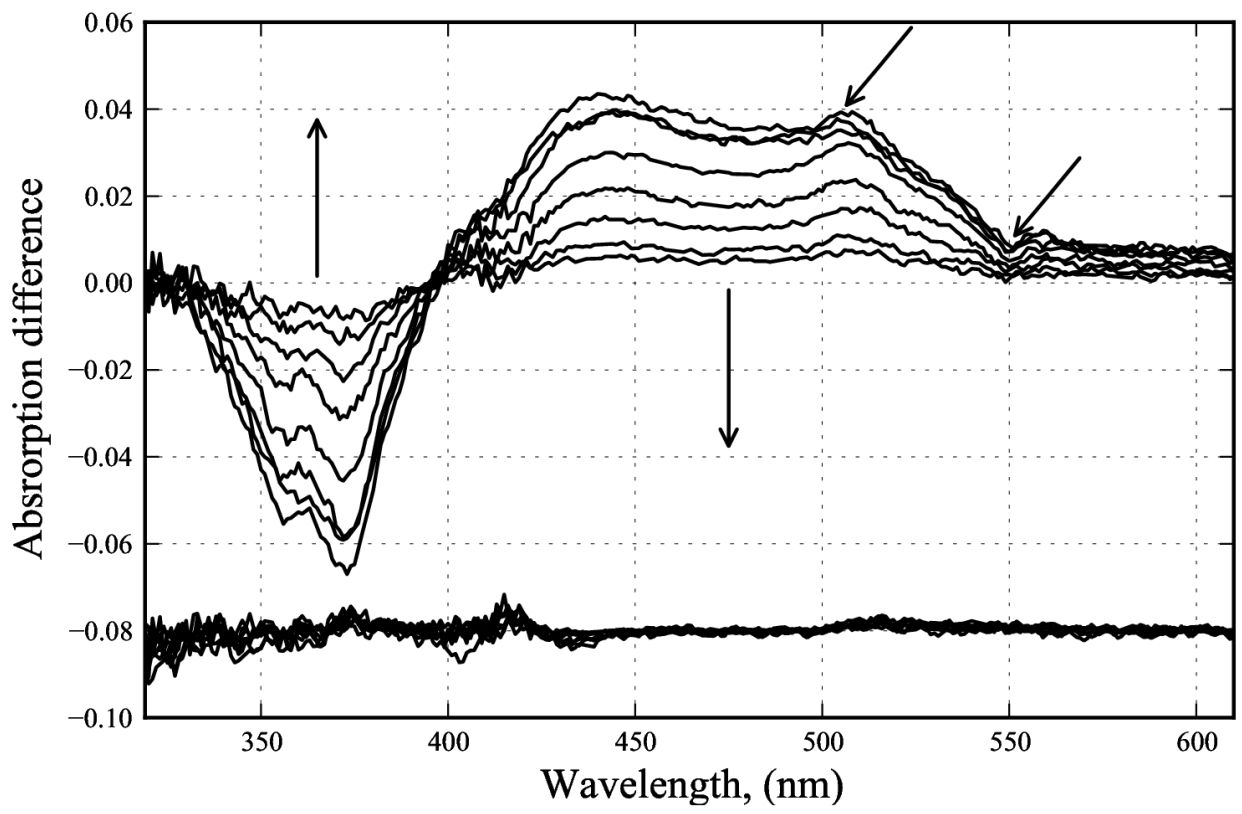

Figure 4.6 Time-resolved difference spectra of cytochrome c labelled with TUPS on Lys86. Delay times after the laser excitation: 250 and $550 \mathrm{~ns}, 1,2,3.5,5,7.5$ and 10 $\mu s$. Vertical arrows indicate the time evolution of the signal, whereas inclined arrows point at the $508 \mathrm{~nm}$ TUPS peak and the $550 \mathrm{~nm}$ ferric minus ferrous (negative) cytochrome $c$ band. The residuals of the fit by the difference spectrum of TUPS* and combined difference spectrum of TUPS and oxidized minus reduced cytochrome $c$ are shown in the bottom, offset by -0.08 .

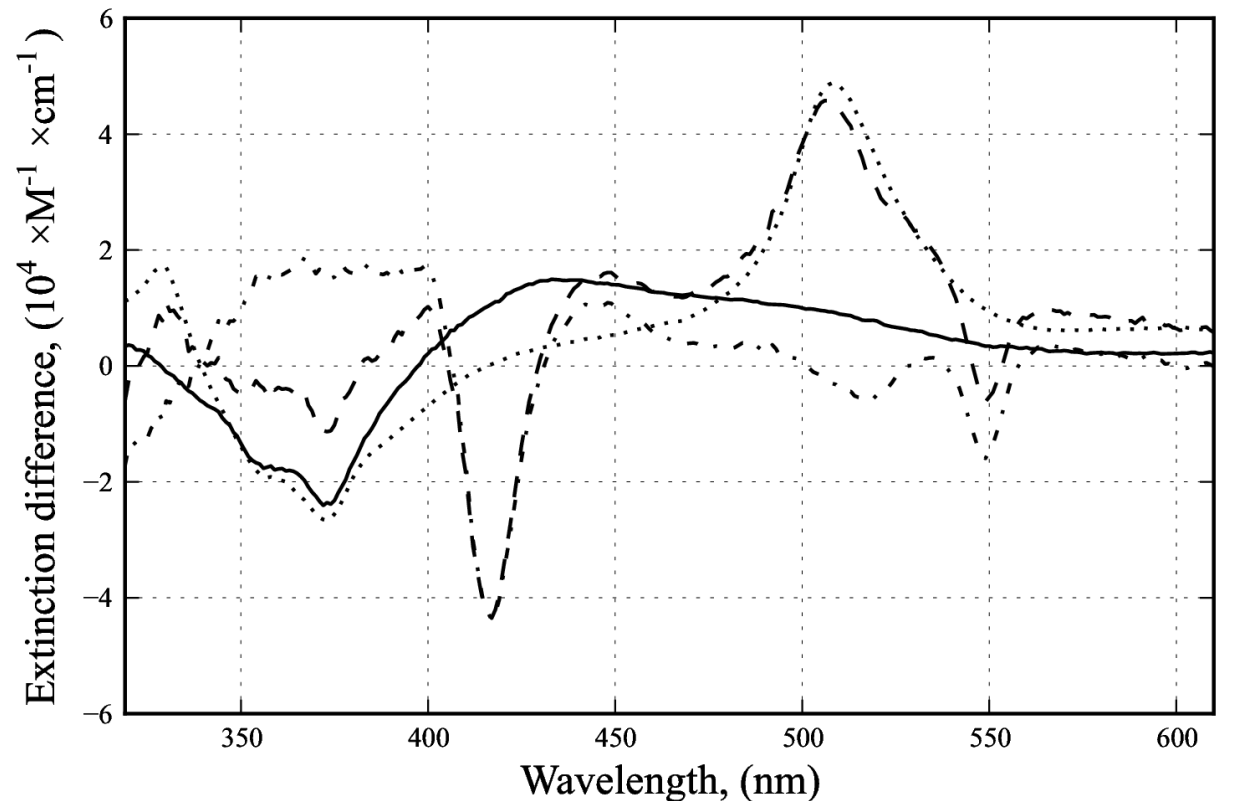

Figure 4.7 Molar extinction difference spectra of TUPS* (solid line), TUPS- (dotted line), the oxidized minus reduced form of cytochrome $c$ (dash-dotted) and of the sum of the latter two (dashed line). 


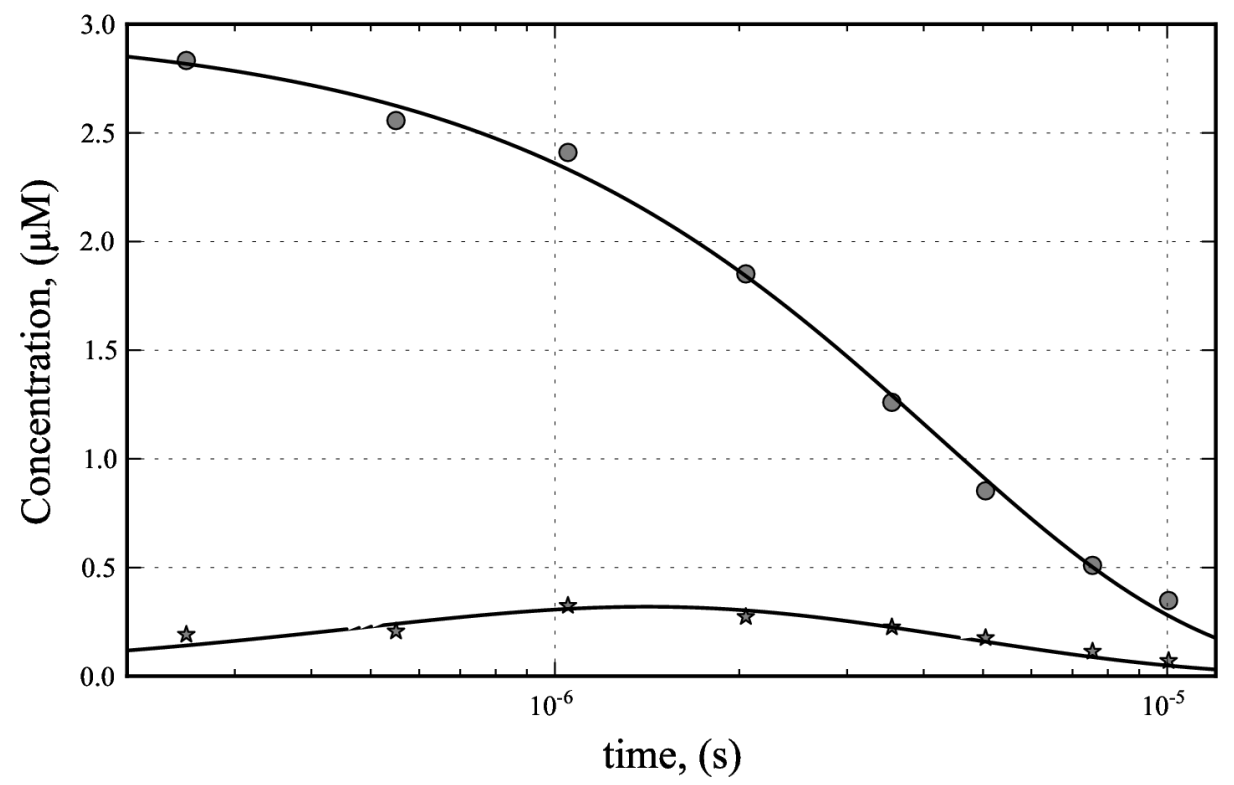

Figure 4.8 Kinetics of TUPS* (circles) and of the species consisting of TUPS ${ }^{-}$and the oxidized heme of cytochrome $c$ (stars) obtained by fitting the data matrix represented in Figure 4.6 by the base spectra in Figure 4.7. Fit of the kinetics by the model described in the text (lines).

spectra of TUPS-TUPS and oxidized minus reduced cytochrome $c$ (dashed line). The latter spectrum was measured as the difference between the spectra of cytochrome $c$ reduced by ascorbic acid and cytochrome $c$ oxidized by ferricyanide. The fit provided the time resolved concentrations for different states of the TUPS-cytochrome $c$ complex (Figure 4.8). Inclusion of the TUPS ${ }^{+}$-TUPS difference spectrum into the base spectrum matrix gave little improvement of the fit of the difference spectra. Moreover, the resulting concentration of this species turned out to be much lower than the other two components and exhibited a random pattern. Taking this and the negligible amount of initially oxidized protein form into account, the previously described transient reduction of initially oxidized cytochrome $c$ by the excited TUPS (Kotlyar et al., 1997b) plays no role in the present experiment. The kinetics of the two forms, TUPS ${ }^{*}$-ferrocytochrome $c$ and TUPS-ferricytochrome $c$, present in the system, were analyzed by the following reaction scheme $\left(\mathrm{k}_{\mathrm{p}}\right.$ : phosphorescence or intersystem crossing, $\mathrm{k}_{\mathrm{f}}$ : forward electron transfer and $\mathrm{k}_{\mathrm{r}}$ : reverse electron transfer:

$$
\begin{aligned}
& \text { cyt-TUPS }^{*} \stackrel{k_{f}}{ } \mathrm{cyt}^{+}-\mathrm{TUPS}^{-} \\
& \text {cyt }^{+}-\mathrm{TUPS}^{-} \stackrel{k_{r}}{ } \mathrm{cyt}-\mathrm{TUPS}
\end{aligned}
$$


Results

$$
\text { cyt-TUPS }^{*} \stackrel{k_{p}}{\longrightarrow} \text { cyt-TUPS }
$$

This scheme is described by following system of differential equations:

$$
\left\{\begin{array}{c}
\frac{d\left[T U P S^{*}-c y t\right]}{d t}=-\left(k_{p}+k_{f}\right)\left[T U P S^{*}-c y t\right] \\
\frac{d\left[T U P S^{-}-c y t^{+}\right]}{d t}=k_{f}\left[T U P S^{*}-c y t\right]-k_{r}\left[T U P S^{-}-c y t^{+}\right]
\end{array}\right.
$$

The system of reaction rate equations has an analytical solution of the following form:

$$
\begin{gathered}
{\left[\operatorname{TUPS}^{*}-c y t\right]=A e^{-\left(k_{p}+k_{f}\right) t}} \\
{\left[\operatorname{TUPS}^{-}-c y t^{+}\right]=A \frac{k_{f}}{k_{p}+k_{f}-k_{r}}\left(e^{-k_{r} t}-e^{-\left(k_{p}+k_{f}\right) t}\right)}
\end{gathered}
$$

for the two electronic forms TUPS ${ }^{*}$-ferrocytochrome $c$ and TUPS-ferricytochrome $c$, respectively. The coefficient $A$ is the initial concentration of TUPS triplet at time zero. Equations 19 and 20 were fitted together to the time dependent concentrations (Figure 4.8) and the solution resulted in the rate constants $\mathrm{k}_{\mathrm{f}}=(2.36 \pm 0.06) \times 10^{5} \mathrm{~s}^{-1}$ for forward electron transfer from the heme to the triplet, and the reverse electron transfer rate constant $\mathrm{k}_{\mathrm{r}}=(1.58 \pm 0.09) \times 10^{6} \mathrm{~s}^{-1}$. The rate constant describing the triplet decay without electron transfer, $\mathrm{k}_{\mathrm{p}}$, remained undetermined because it is about 3 orders of magnitude smaller (cf. above) than the electron transfer rates, so that practically all triplet excited forms of TUPS decay via the electron transfer pathway. Since the reverse electron transfer from the negative radical to the oxidized heme is more than 10 times faster than the forward electron transfer, the accumulation of the oxidized cytochrome $c$ species is rather low. It is also interesting to note that in such a situation the phenomenological rates of the rise and the decay of the TUPS-ferricytochrome $c$ species correspond roughly to the reverse and forward electron transfer rates, respectively.

We have also reexamined the electron transfer in the TUPS-ferricytochrome $c$ system. Figure 4.9 (left) shows difference spectra acquired on the TUPS-cytochrome $c$ complex with TUPS bound to the genetically introduced cysteine in position 8 . The shape of the spectrum collected at $350 \mathrm{~ns}$ after the actinic laser pulse is dominated by TUPS triplet features. Consecutive difference spectra from later delays show the 

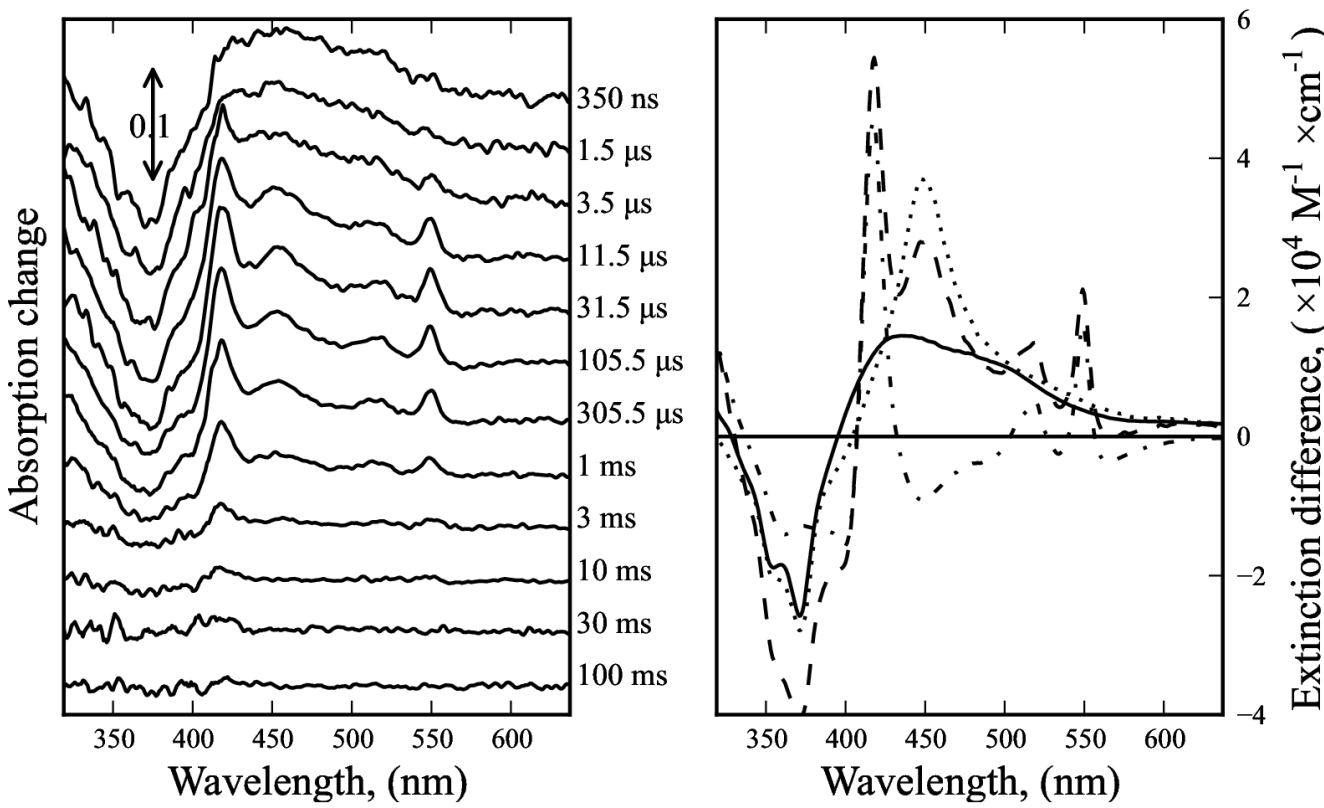

Figure 4.9 Time-resolved difference spectra at the indicated time delays after the actinic laser pulse, measured on the cytochrome c labelled with TUPS on the genetically introduced cysteine at position 8 (Left). Base difference spectra for the fit of the timeresolved spectra: TUPS ${ }^{*}$ - TUPS (solid line), TUPS ${ }^{+}$-TUPS (dotted line), cytochrome c reduced-cytochrome c oxidized (dash-dotted line) and the sum of the latter two (dashed line).

appearance of peaks characteristic of the reduced cytochrome $c$ and the TUPS cation radical, indicating forward electron transfer from TUPS triplet to the heme prosthetic group of cytochrome $c$. Eventually, the ground state of TUPS and the oxidized cytochrome $c$ recover via reverse electron transfer, when the reduced heme is reoxidized by the cation radical of TUPS, as demonstrated by the diminishing features in the millisecond time domain (Figure 4.9, left). The matrix of difference spectra can be fitted by the spectra of the expected intermediates (Figure 4.9, right), the TUPS triplet minus ground-state spectrum, and the combination of the TUPS positive radical minus ground-state and the cytochrome $c$ reduced minus oxidized difference spectra.

The result of this fit is the time-dependent concentration of the triplet (not shown) and that of the species with the electron temporarily residing on the heme, (Figure 4.10, left, circles). Using the single wavelength option of our setup, the redox state of cytochrome $c$ was also followed at $550 \mathrm{~nm}$, at the maximum of the characteristic peak of reduced cytochrome $c$. The TUPS triplet contribution was eliminated by subtracting the properly weighted trace measured at $562 \mathrm{~nm}$. At $562 \mathrm{~nm}$ the combined spectrum of TUPS ${ }^{+}$-TUPS and cytochrome $c$ reduced-oxidized has zero crossover, therefore the 
absorption change at this wavelength shows the kinetics of TUPS*-TUPS exclusively. The time-dependent concentration of the reduced cytochrome $c$ (and TUPS ${ }^{+}$) obtained from the fit to the multichannel data overlaps well with the single-wavelength kinetic trace (Figure 4.10, left, black trace). The high signal to noise ratio and high temporal resolution of the single-wavelength trace allows studying the kinetics of the forward and, especially, the reverse electron transfer process in detail. A single exponential fit of rise and decay with baseline was evidently insufficient (not shown), whereas the $1+4+$ baseline fit is acceptable (Figure 4.10, left, red line). The hybrid least squares/maximum-entropy method (MEM) was also applied to the kinetics in Figure 4.10 (left). The rate constant distribution shows a broad peak for the forward electron transfer and four well-resolved peaks for the reverse electron transfer (Figure 4.10, right), with a goodness of fit $\mathrm{X}^{2}=0.966$. The MEM-assisted discrete exponential fit yielded individual rate constants for the exponentials corresponding to the bands in the maximum entropy distribution. The individual exponential components and the baseline
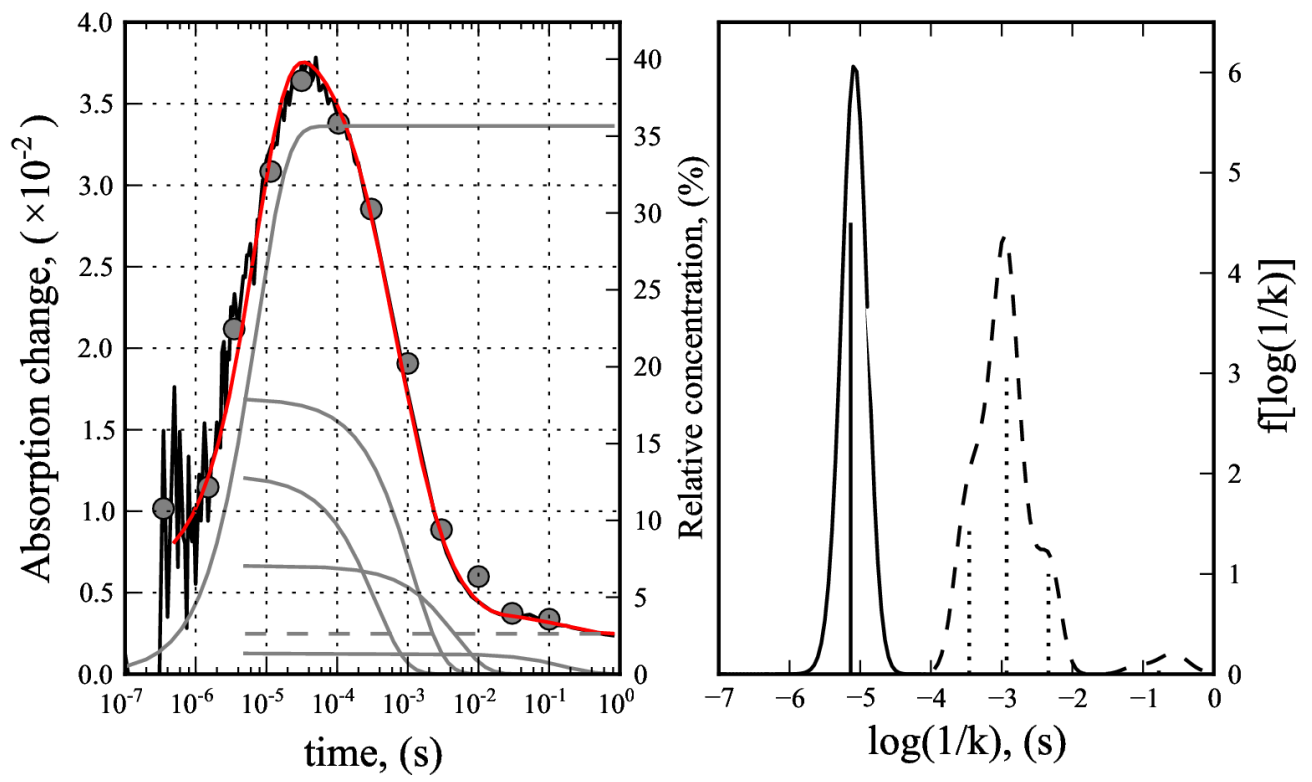

Figure 4.10 Left: Kinetics of the TUPS $\sim$ cyt $t_{\text {red }}$ species from the fit of the time resolved spectra in Figure 4.9, expressed as percentage of the total TUPS labelled protein concentration (circles), and the absorption kinetics measured as singlewavelength $\Delta A_{550}-\Delta A_{562}$ (black trace). Results of the multiexponential fit (red curve), the individual exponential components (grey), and baseline (dashed grey). Right: Distribution of the time constants for the forward (solid line) and reverse (dashed line) electron transfer as obtained by the maximum entropy fit of the kinetics in the left panel of the figure. The individual time constants from the multiexponential fit are marked as vertical lines proportional to the corresponding amplitudes. 
Table 1 Result of the multiexponential fit to the forward and reverse electron transfer kinetics measured as $\Delta A_{550}-\Delta A_{562}$ on the four different cytochrome $c$ - TUPS complexes. $k_{1}$ and $A_{1}$ describe the rise phase; $k_{2-5}$ and $A_{2-5}$ describe the decay phase; $k_{\text {decay }}$ $=\sum A_{i} k_{i} \sum A_{i}$ for the decaying phases.

\begin{tabular}{|c|c|c|c|c|c|}
\hline \multicolumn{2}{|l|}{ TUPS labelled residue } & K8 & $\mathrm{K} 8 \mathrm{C}$ & K39 & K39C \\
\hline \multirow{6}{*}{ Rate constants $\left(\mathrm{s}^{-1}\right)$} & $\mathrm{k}_{1}$ & $7.95 \times 10^{4}$ & $1.37 \times 10^{5}$ & $5.79 \times 10^{4}$ & $5.26 \times 10^{4}$ \\
\hline & $\mathrm{k}_{2}$ & 1525 & 2878 & 1654 & 1554 \\
\hline & $\mathrm{k}_{3}$ & 339 & 852 & 540 & 313 \\
\hline & $\mathrm{k}_{4}$ & 131 & 218 & 92 & 8 \\
\hline & $k_{5}$ & & 6 & & \\
\hline & $\mathrm{k}_{\text {decay }}$ & 626 & 1269 & 1113 & 1116 \\
\hline \multirow{6}{*}{$\begin{array}{l}\text { Relative } \\
(\%)\end{array}$} & $A_{1}$ & -90.00 & -77.00 & -83.00 & -68.00 \\
\hline & $A_{2}$ & 26 & 25 & 52 & 62 \\
\hline & $A_{3}$ & 59 & 49 & 43 & 27 \\
\hline & $\mathrm{A}_{4}$ & 14 & 16 & 3 & 5 \\
\hline & $A_{5}$ & & 3 & & \\
\hline & baseline & 1 & 7 & 2 & 6 \\
\hline
\end{tabular}

are shown in the left panel of Figure $4.10\left(\mathrm{X}^{2}=0.806\right)$, and the exponentials are also represented in the right panel of the same figure, as lines at the appropriate $\log _{10}(t)$ abscissa and with heights proportional to their amplitudes. The same method of analysis was applied to the transient kinetics measured on K8-, K39-, and K39C-labelled samples. All results are summarized in Table 1. For the latter three samples the MEMNLS program recommended a fit with $1+3$ discreet exponentials. From the maximum entropy fit one can draw the conclusion that the multiexponential character of the electron transfer between TUPS and the heme is real. Particularly, the reverse electron transfer cannot be explained by a single kinetic phase even with a distributed rate constant.

The geometrical distances between the heme and the labelled lysines, calculated from the crystal structure, are listed in Table 2. The distance to the heme is consistently longer from $\mathrm{K} 8$ than from $\mathrm{K} 39$, whether it is calculated to the heme iron, to the heme edge or to the edge of the $\pi$-electron system of the heme. Since the attachment of TUPS to cytochrome $c$ does not alter its redox potential (Kotlyar et al. 1997b), the driving force of the electron transfer remains the same, and the electron transfer rate is solely 
Table 2: Geometrical distances between the end of the lysine side chains and the heme, calculated from the crystal structure of cytochrome $c$.

\begin{tabular}{|l|l|c|c|}
\hline & TUPS labelled residue & K8 & K39 \\
\hline \multirow{3}{*}{ Distances $(\AA)$ Nz to.. } & heme Fe & 21.3 & 19.5 \\
\cline { 2 - 4 } & heme edge & 15.6 & 11.4 \\
\cline { 2 - 4 } & heme $\pi$-electron system & 17.3 & 15.3 \\
\hline
\end{tabular}

the function of the donor-acceptor distance and the distance decay constant, as described by the Marcus theory (Equation 4). The theory predicts that the rate constant of electron transfer should be at least 6-12 times faster for K39 with values of $\beta$ ranging from 1.0 to 1.4 , even when the smallest difference in the lysine - heme distance, $1.8 \AA$, as calculated from the lysines to the $\mathrm{Fe}$ atom, is considered. Using the edge-to-edge distance one obtains at least 2 orders of magnitude rate difference. However, the measured electron transfer rates show only marginal difference between the K8-TUPS and K39-TUPS samples. The effective reverse electron transfer rate, calculated as $\sum A_{i} k_{i} / \sum A_{i}, i=2-4$, is 626 and $1113 \mathrm{~s}^{-1}$ for K8-TUPS and K39-TUPS, respectively, and the forward rate is even faster for K8-TUPS. It is also obvious that the experimental rates do not conform to the expected distance dependence if the distance is defined along the covalent link between the dye and the protein. The replacement of the lysines by cysteines increases the total covalent bond length to the aromatic part of the dye by one unit. Yet, the measured rates do not decrease $\left(\sum \mathrm{A}_{\mathrm{i}} \mathrm{k}_{\mathrm{i}} / \sum \mathrm{A}_{\mathrm{i}}\right.$ changes from 626 to 1269 and from 1113 to $1116 \mathrm{~s}^{-1}$ for the $\mathrm{K} 8 \mathrm{C}$ and the $\mathrm{K} 39 \mathrm{C}$ replacement, respectively).

\subsection{Molecular dynamics and electron transfer parameter and pathway calculations}

The obvious explanation for multiexponential behaviour of electron transfer between TUPS and the heme is sample heterogeneity. However, at the given $\mathrm{pH}$, cytochrome $c$ is in one of its possible five conformations (Theorell and Åkesson, 1941). As the distribution of the rate constants exhibits well resolved peaks (Figure 4.10), the conformational heterogeneity (ensemble of conformational substrates) of the protein moiety itself cannot be responsible for such behaviour, as it is usually observed at much lower temperatures, below the vitrification point of the surrounding solvent (Parak and Frauenfelder, 1993) or associated with dynamic phase transition (Dioumaev and Lanyi, 


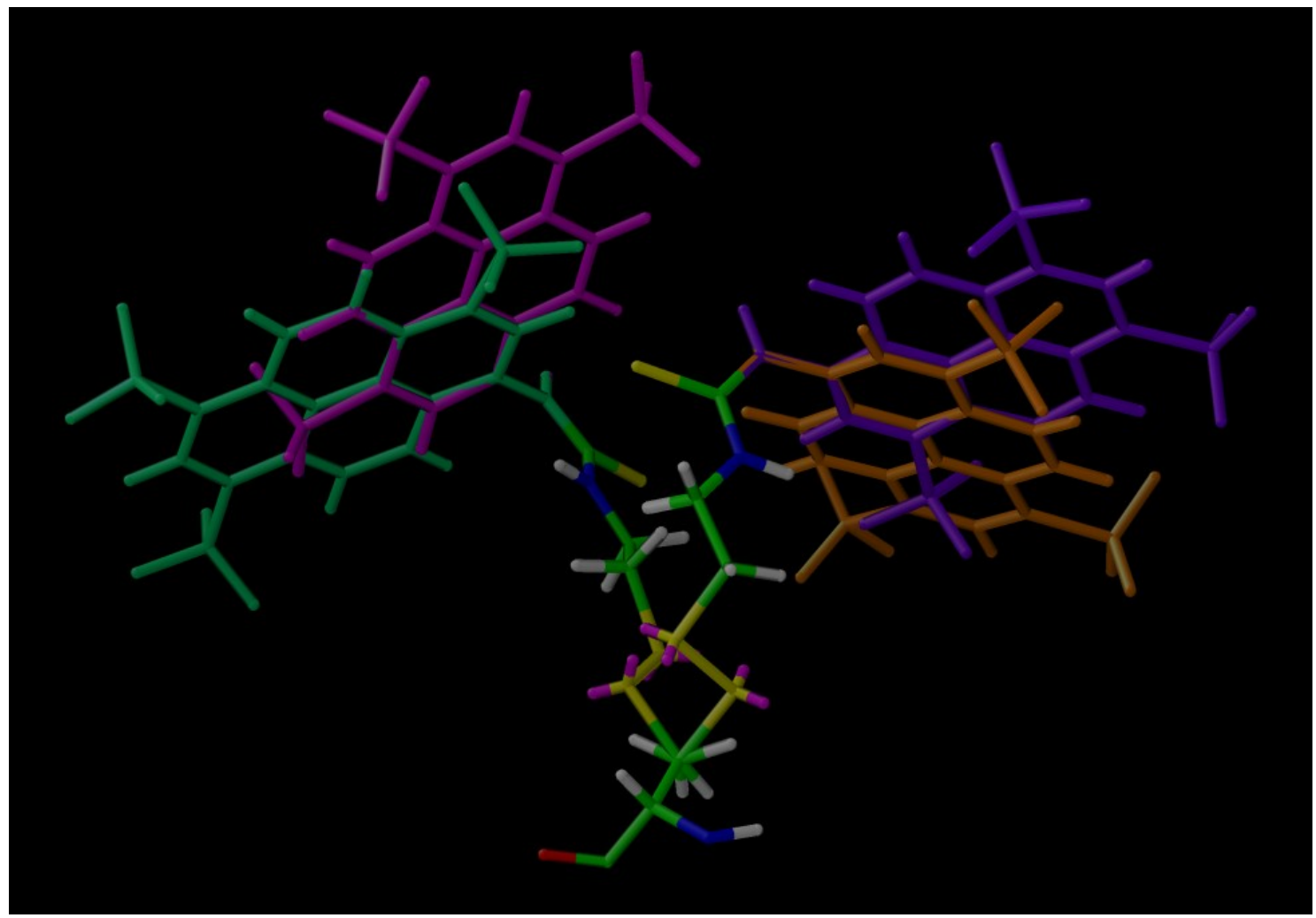

Figure 4.11 Initial conformations of the TUPS-cysteine moiety for the MD calculations.

2008), and it is expected to average out at room temperature on the time scale of these electron transfer processes. To investigate the possibility of the TUPS moiety occupying several positions relative to the protein moiety, and to find such possible conformations, allowed by the rather flexible linker between the two and by the size (geometry) of TUPS, we decided to perform molecular dynamics calculations. The X-ray structure of oxidized horse heart cytochrome $c$ (1HRC.PDB) was used as a starting structure. After mutating the lysine at the $8^{\text {th }}$ position to cysteine in-silico, TUPS-cysteamine adduct was connected to it. The protein part was positionally restrained, whereas the side chain of the Cys 8 amino acid and all the atoms of TUPS were left freely moving. The energy of the system was minimized, and then, $1 \mathrm{~ns}$ molecular dynamics calculations were carried out with $1 \mathrm{fs}$ steps at $300 \mathrm{~K}$. The trajectories were sampled every $1 \mathrm{ps}$. Simulations were started from four different conformations of the dye moiety (Figure 4.11). Solvent effects were represented implicitly by a medium with a dielectric constant of 80 . No periodic boundary conditions were assumed in these calculations. Even so, this preliminary calculation can already show geometrically feasible conformations of TUPS and provide the basis for the qualitative (if not quantitative) interpretation of the electron transfer rates obtained experimentally. During the MD simulation, the TUPS 


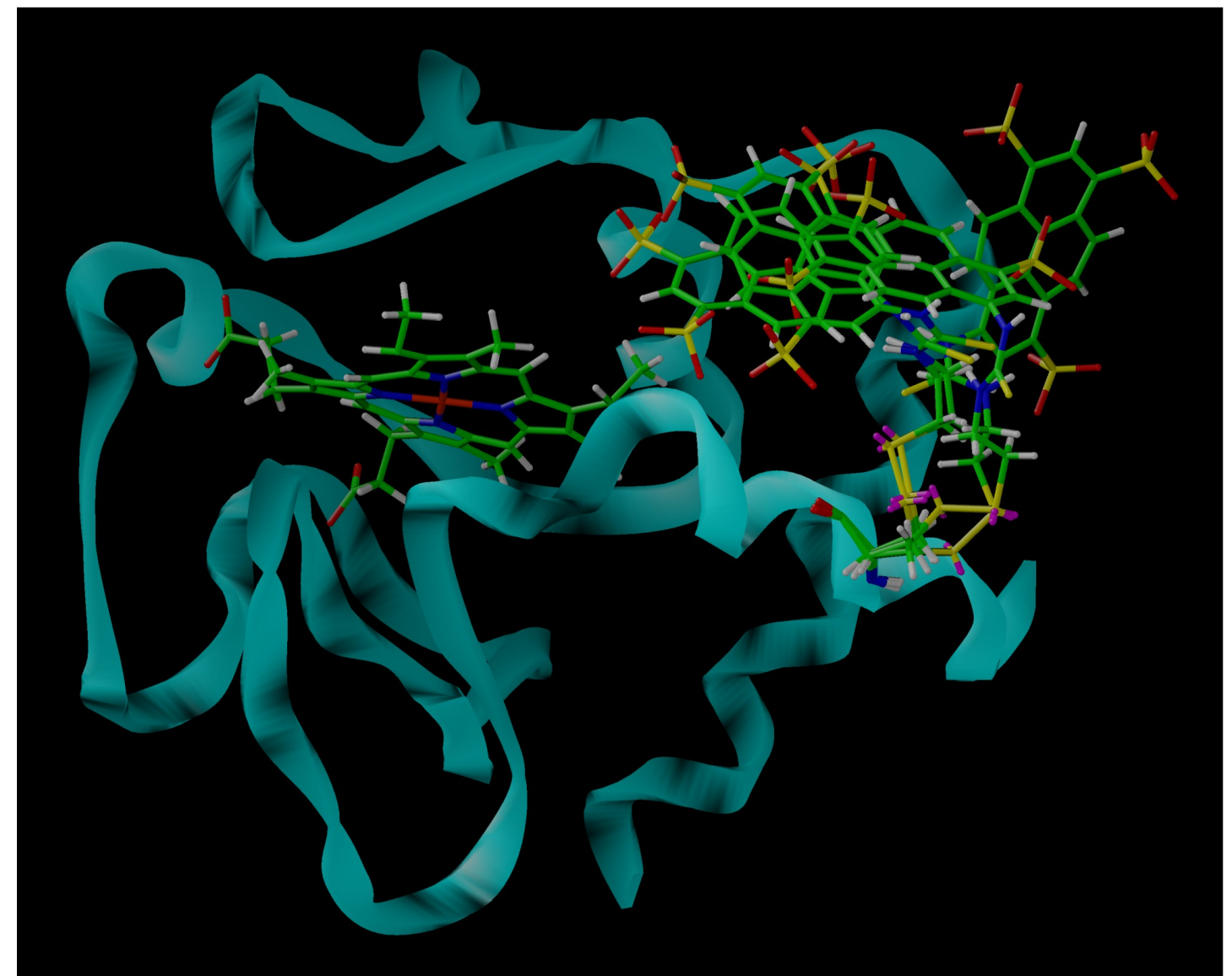

Figure 4.12 Structure of the representative conformations of TUPS covalently bound to cysteine 8 of cytochrome c. Three out of the four similar locations as well as one significantly different position are shown.

moved initially freely above the surface of the cytochrome $c$, but finally it approached the protein surface and occupied several positions. The trajectories for all MD calculations showed that the label spent most of the time in and close to these sterically allowed conformational states. Figure 4.12 depicts representative frames of these conformations, selected from the trajectories of the MD simulation well after the initial transients. It must be noted that there was no interconversion between three of the four stationary conformations, which were, therefore, determined by the initial TUPS conformations assumed. The first three TUPS positions adhere near one position, whereas the fourth location is markedly different from the other ones. The calculations also yielded less-dominant geometrically possible conformations for the TUPS, which were characterized by shorter dwell times in a certain position compared to the four conformations mentioned above (not shown). For the four dominant structures optimal electron transfer pathways and electron transfer parameters (packing density, distance decay constant, and electronic coupling strength) between TUPS and the heme, were 


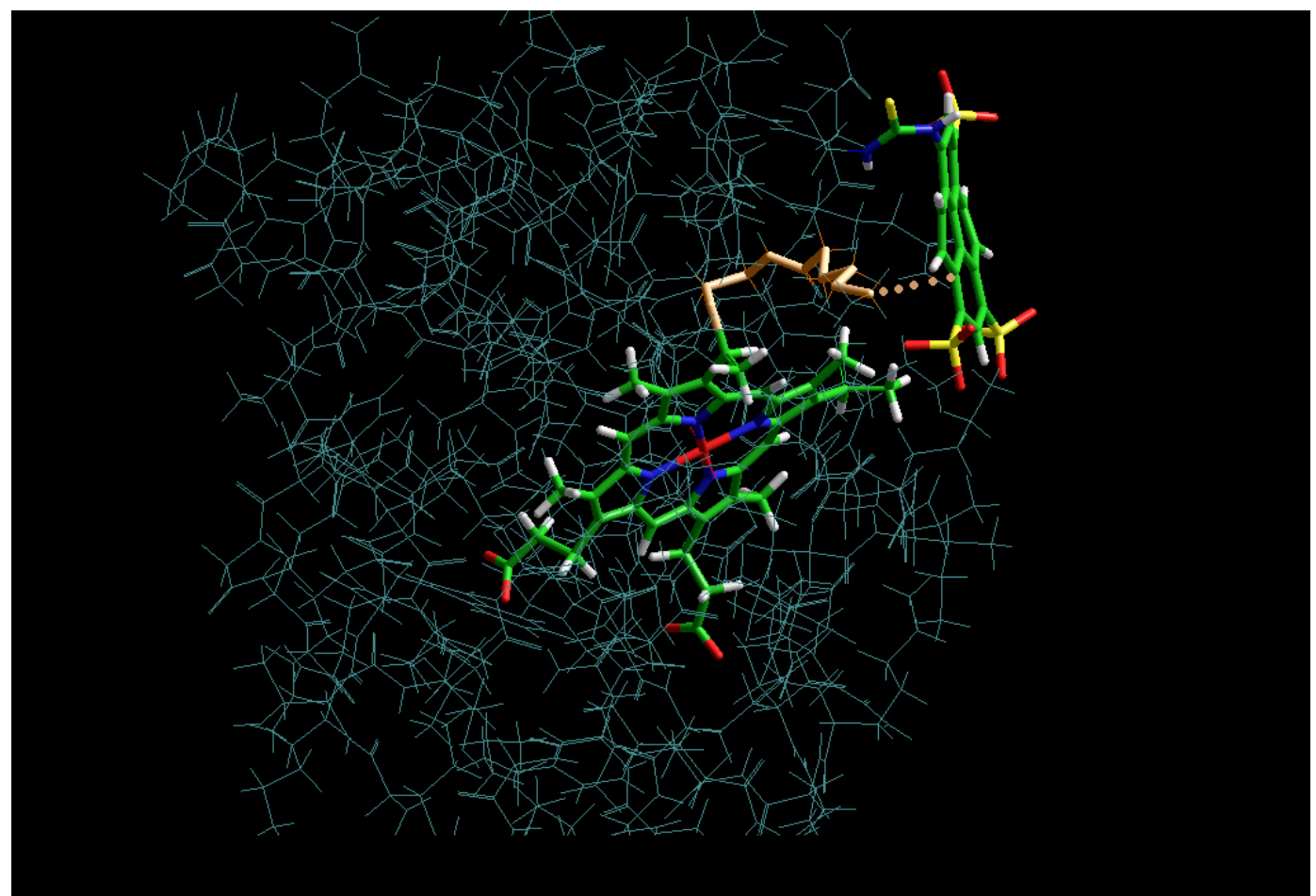

Figure 4.13 The optimal electron transfer pathway (orange) calculated for the stationary conformation no. 2 of the K8C-TUPS cytochrome c system. The electron donor (TUPS) and acceptor (heme) are shown in coloured stick representation. The dotted orange line in the pathway corresponds to the throughspace jump, and the continuous line corresponds to electron transfer through covalent bonds.

calculated using the HARLEM software (Table 3). The packing density characterizes the average packing density along all lines connecting the atoms of donor and acceptor, by considering the fractional length of the lines passing within the van der Waals radius of medium atoms. It is dimensionless, and ranges from 0 to 1 . The electron donor and acceptor, in these calculations, were defined as the four-ring aromatic $\pi$-electron system of the dye and all atoms contributing to the heme, respectively. The calculations consider nearest edge-to-edge distances. Conformations 2 and 3 appear equivalent in terms of electronic coupling strength; therefore, they are expected to result in very similar electron transfer rates, whereas conformations 1 and 4 are different. Thus, the combination of MD and electron transfer calculations provide a qualitative explanation for the multiexponential electron transfer kinetics. As it is seen from results of MD, the geometry of the TUPS-linker moiety allows several distinct positions for TUPS, and it may facilitate substantially different electron transfer efficiencies or pathways between TUPS and the heme. An example of the calculated pathways is shown in Figure 4.13. 
The path connecting the edge of TUPS and that of heme starts by a jump from the TUPS pyrene rings to the protein surface and avoids the covalent link via the scaffold of the label and the supporting Cys 8. When the carbon atom from the thiouredo group was selected as the sole source on the electron donor, representing the border of the aromatic part of the dye and the covalent link to the protein, a different optimal pathway was found (not shown). This pathway, however, also includes a through space jump to the protein and, therefore, does not follow the supporting cysteine side chain.

Table 3 Calculated electron transfer parameters for the four dominant positions of TUPS covalently bound to Cys8.

\begin{tabular}{|c|c|c|c|c|}
\hline Number of stationary conformation & 1 & 2 & 3 & 4 \\
\hline Donor-acceptor edge-to-edge distance $(\AA)$ & 6.83 & 8.54 & 8.33 & 10.64 \\
\hline $\begin{array}{c}\text { Packing density between donor and acceptor }(\rho, \\
\text { dimensionless })\end{array}$ & 0.74 & 0.69 & 0.66 & 0.62 \\
\hline $\begin{array}{c}\text { Average distance decay constant }(\beta) \\
\text { Dimensionless coupling square }\left(\mathrm{H}_{\mathrm{DA}}{ }^{2}\right)\end{array}$ & 1.41 & 1.50 & 1.55 & 1.61 \\
\hline
\end{tabular}

\subsection{The photocycle of photoactive yellow protein}

Absorption changes were measured on PYP at $\mathrm{pH}$ 8.2, a $\mathrm{pH}$ value approximately in the middle of the plateau in the $\mathrm{pH}$ dependence of the $\mathrm{pG}$ recovery rate. Existing photocycle models assume that at this $\mathrm{pH}$ the $\mathrm{pG}$ resting state is present in only one of its $\mathrm{pH}$ dependent forms, so the sample is homogeneous. Hofmeister salts should have an effect especially on the rates of the molecular transitions involving conformational changes resulting in changes in the hydration of the protein. Therefore, measurements were also performed in the presence of different Hofmeister anions, namely $0.66 \mathrm{M}$ of $\mathrm{NaF}, \mathrm{NaCl}, \mathrm{NaI}, \mathrm{NaNO}_{3}$ and $\mathrm{NaClO}_{4}$. The analysis of data included the determination of the number of spectrally and kinetically distinct intermediates, the estimation of their spectra used as initial guess (as "seed spectra") in the consecutive model fit to the spectrotemporal matrix and thereby the determination of the rate constants in the scheme of the model. The procedure will be demonstrated on the experiment carried out in $0.66 \mathrm{M} \mathrm{NaCl}$ solution. The purpose of the comparison of the data with and "without" salt was to identify possible salt-dependent steps in the photocycle. 
Results
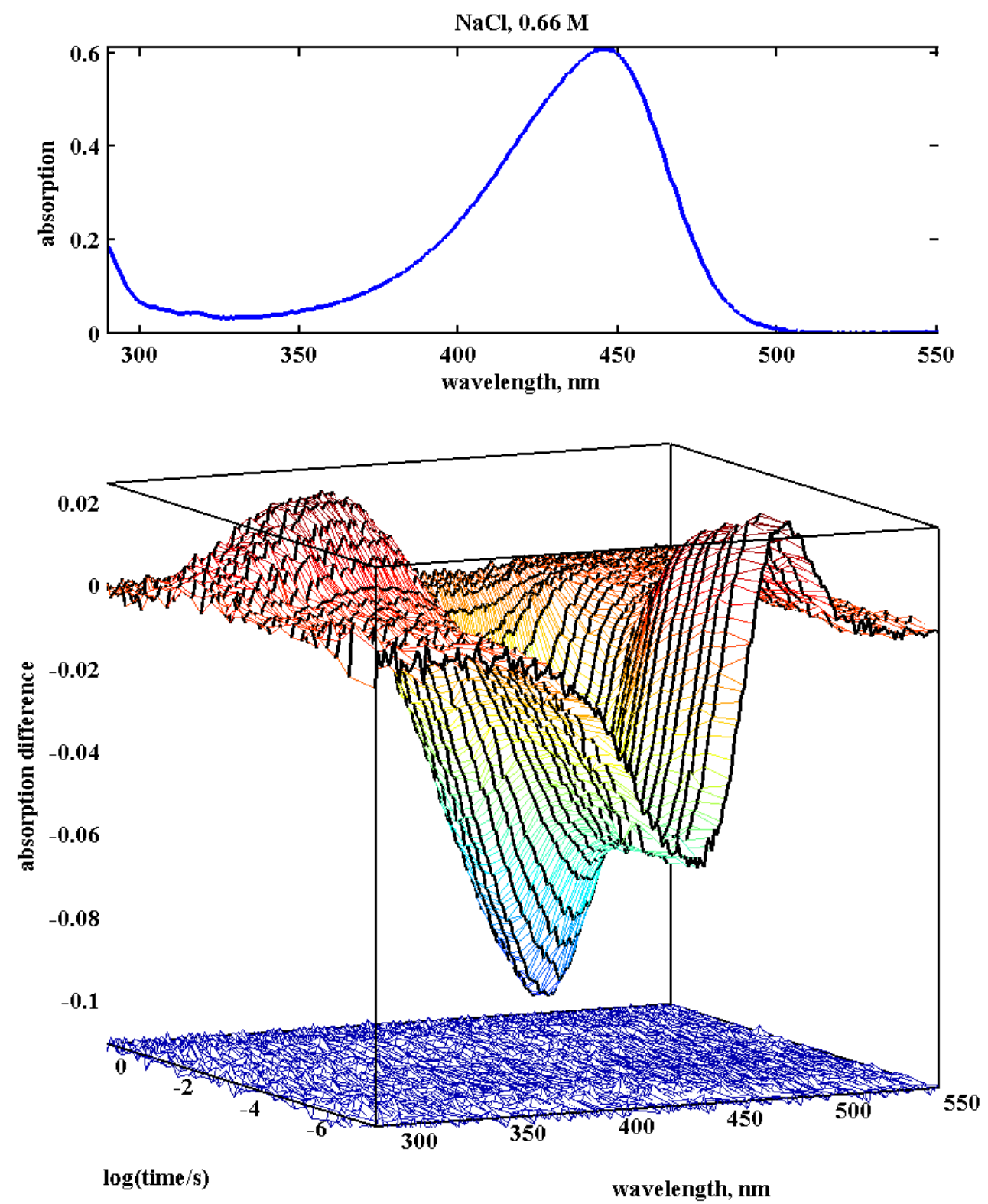

Figure 4.14 Absorption spectrum of PYP sample (top). SVD reconstituted flash induced difference spectra of PYP (bottom). Measured in the presence of $0.66 \mathrm{M}$ $\mathrm{NaCl}(\mathrm{pH}=8.2)$. Residuals of the model fit are plotted with negative offset.

\subsubsection{Singular value decomposition (SVD) and multiexponential fit}

Difference spectra were measured on PYP at 27 increasing time delays after laser flash excitation, logarithmically spaced between $60 \mathrm{~ns}$ and $6.5 \mathrm{~s}$. To estimate the number of spectrally and kinetically independent components in the PYP photocycle, all datasets were subjected to SVD analysis. Figure 4.14 shows the absorption spectrum of 

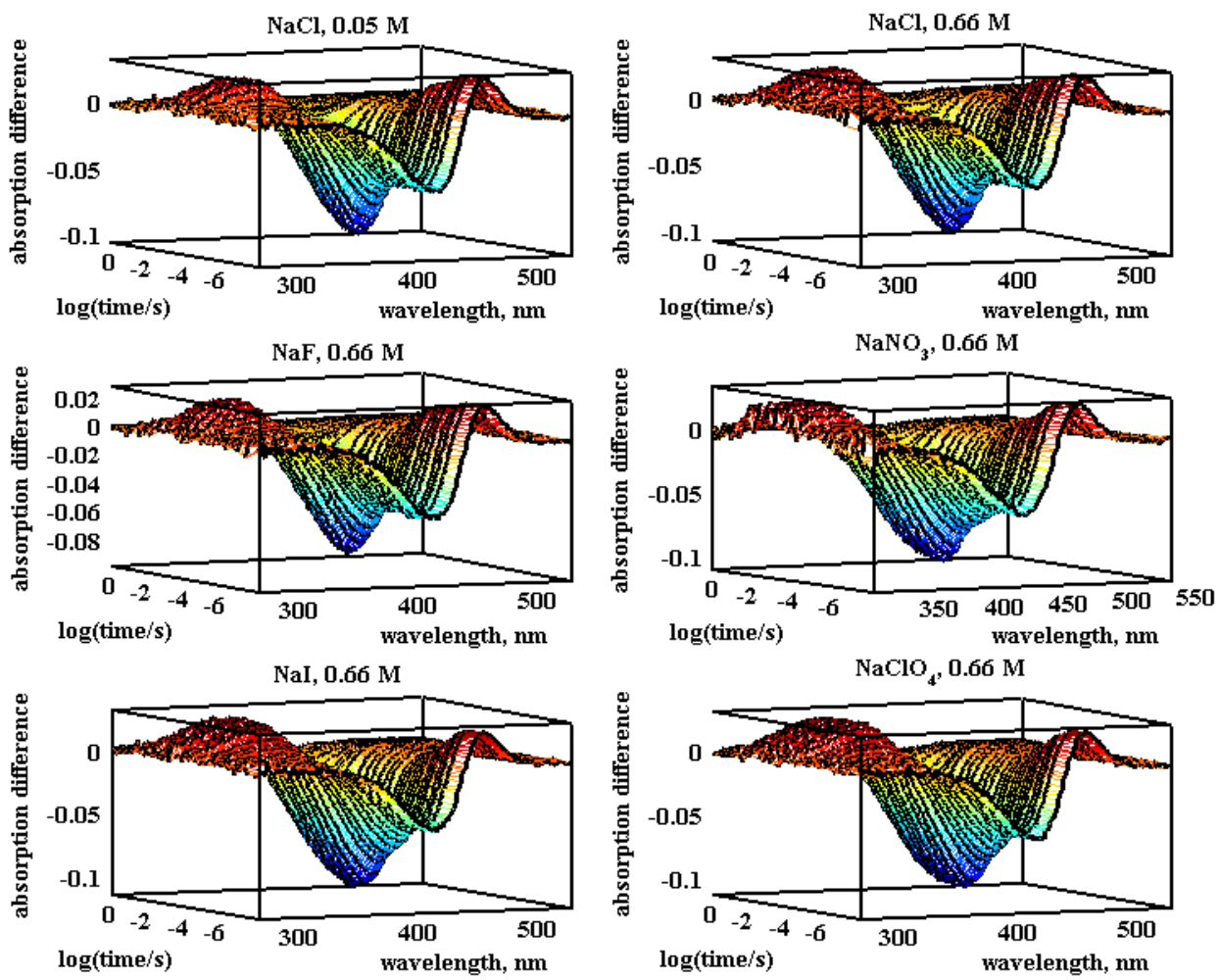

Figure 4.15 Time-resolved difference spectra of PYP at different salt conditions. pG (top) and the spectrotemporal dataset, measured in the presence of $0.66 \mathrm{M} \mathrm{NaCl}$ (bottom). The first difference spectra show the depletion of the resting state, and the instantaneous (on the scale of our time resolution) formation of a red shifted species. Within $10 \mu \mathrm{s}$, the signal at $470 \mathrm{~nm}$ starts to decay, while there is no sign of the recovery of the resting state. This is consistent with the $\mathrm{pR}_{1}$ to $\mathrm{pR}_{2}$ transition, described earlier for PYP in this time domain (Hendriks et al., 2003). The two red shifted intermediates, $\mathrm{pR}_{1}$ and $\mathrm{pR}_{2}$ are spectrally almost indistinguishable. In the time interval between $18 \mu$ s and $10 \mathrm{~ms}$, the decrease in the absorption at $470 \mathrm{~nm}$, accompanied by an increase of the absorption in the UV region is the sign of the transition from the red shifted intermediate(s) to the blue sifted one(s). The absorption signal in the UV reaches its maximum at $10 \mathrm{~ms}$. By this time the positive signal in the red part of the spectrum disappears. The resting state of the protein starts to recover as the signal decays on the timescale of seconds. The isosbestic point in the blue region indicates that the regeneration of the photo-bleached protein proceeds via one spectral component, however, it does not exclude an equilibrium mixture between intermediates. The data, measured in the presence of different anions or "without" salt, exhibit similar behaviour 
(Figure 4.15).

The determination of the rank of the data matrices was based on the rapid drop of the singular values and on the diminishing values of the autocorrelations of the spectral and kinetic eigenvectors. In those cases, where some of the low order spectral (U) and kinetic (V) vectors exhibited high autocorrelation, the rotation algorithm was applied to "pull forward" the information content represented by these eigenvector pairs, which would be discarded otherwise based on the noise criteria (i.e. the singular values) alone. All data matrices had a rank of 3, i.e. all spectral and kinetic information could be reconstructed within noise using the first 3 eigenvectors, giving small and structureless residuals. Figure 4.16 shows the results of the SVD decomposition for the dataset measured in the presence of $\mathrm{NaCl}$. The spectral eigenvectors $(\mathbf{U})$ are plotted on the left, and the corresponding kinetic eigenvectors $(\mathbf{V})$ multiplied by their singular values on the right. The three significant weighted kinetic vectors were globally fitted by the sum of 5 exponentials (Figure 4.16 right column, red lines). The vertical black lines in the $\mathbf{V}$ vector plots represent the exponential time constants (or reciprocal rate constants) obtained by the fit: three for the rising part and two for the decay. The number of phenomenological rates (5) is also in accordance with the photocycle model which turned out to fit all data sets satisfactorily (see below). In a kinetic scheme of first order transitions the number of exponential processes equals that of the intermediates (this is true even with schemes containing reversible transitions, branches or parallel routes). Figure 4.17 shows the wavelength-dependent amplitudes (B spectra) of the five exponential components for all datasets. Again, reassuringly, the overall pattern and the relative amplitudes of these B spectra are rather similar for the different experiments. Similarly, the spectral eigenvectors ( $\mathbf{U}$ vectors) are rather similar for all experiments (not shown). These facts already forebode that the spectra of the photocycle intermediates should be very similar in different salts (or in their absence).

Five exponentials where necessary to obtain an adequate fit (right column in Figure 4.16) as compared to the 3 exponentials reported in Joshi et al. (2006) at alkaline $\mathrm{pH}$ in low salt concentration. The fastest transition we report here was not observed in the Joshi et al. measurement due to their limited time scale, which starts at $8 \mu$ s. The difference in the salt concentration is also expected to change the distribution of the phenomenological rate constants. The additional slow, $5^{\text {th }}$ exponent in our measurements 

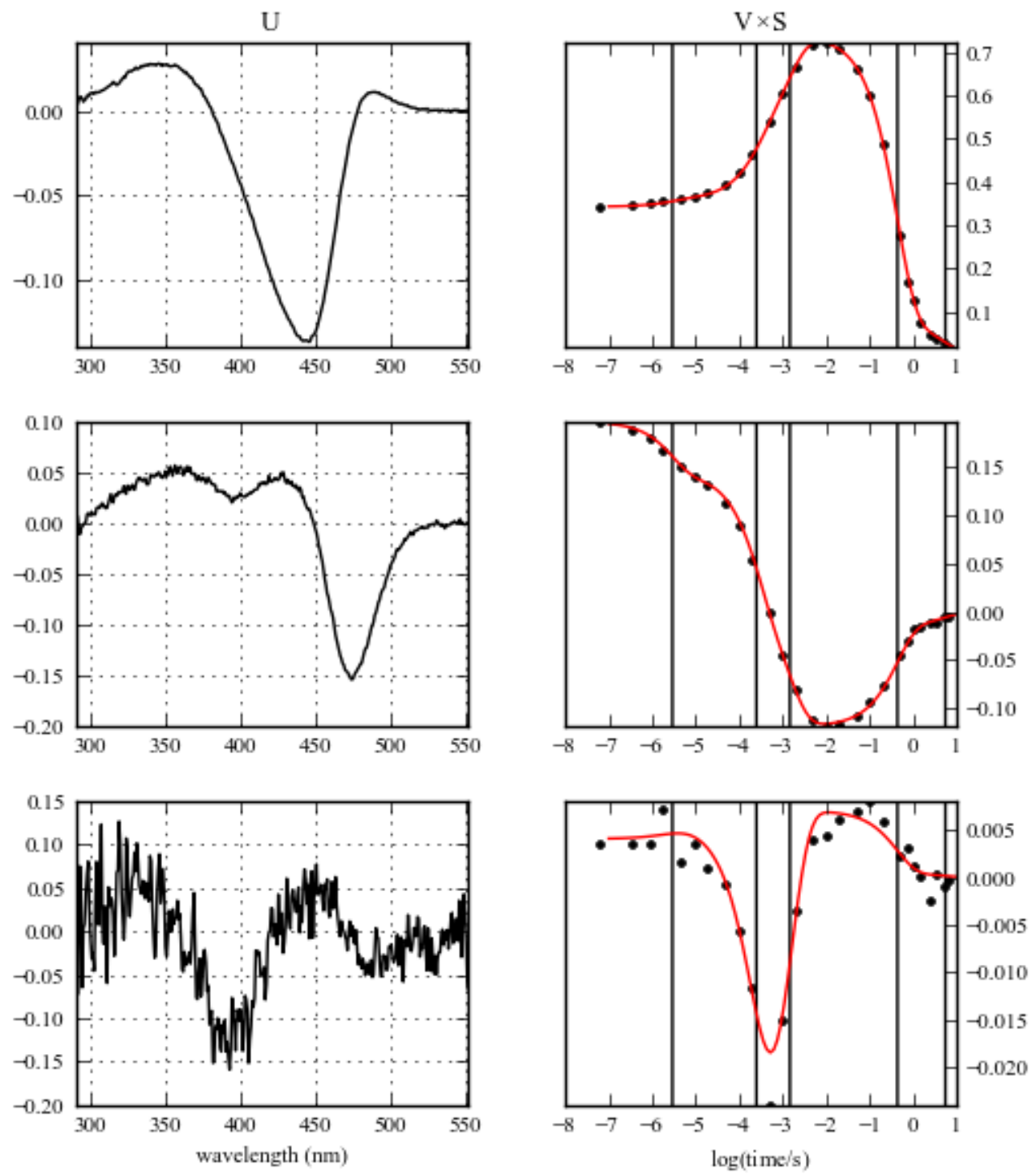

Figure 4.16 The first 3 significant $U$ vectors (left column), and the corresponding $V$ vectors multiplied by their eigenvalues (right column, dots). Result of the global multiexponential fit (red lines). Vertical lines represent the logarithm of the reciprocal of the obtained exponential rates.

is corroborated by the biphasic recovery of the dark state reported before (Hendriks and Hellingwerf, 2009). It must be noted that this is different from the biphasic folding observed after continuous illumination of PYP especially in the presence of denaturants (Lee and Hoff, 2008), because the slow component in those experiments was significantly slower than the slow component reported here. The exponential amplitude spectra (B-spectra) for the $0.66 \mathrm{M} \mathrm{NaCl}$ experiment are re-plotted in Figure 4.18 (top). Visual inspection of these spectra already allows to draw some conclusions about the spectra of the intermediates and the photocycle. The first B-spectrum corresponding to a 
Results
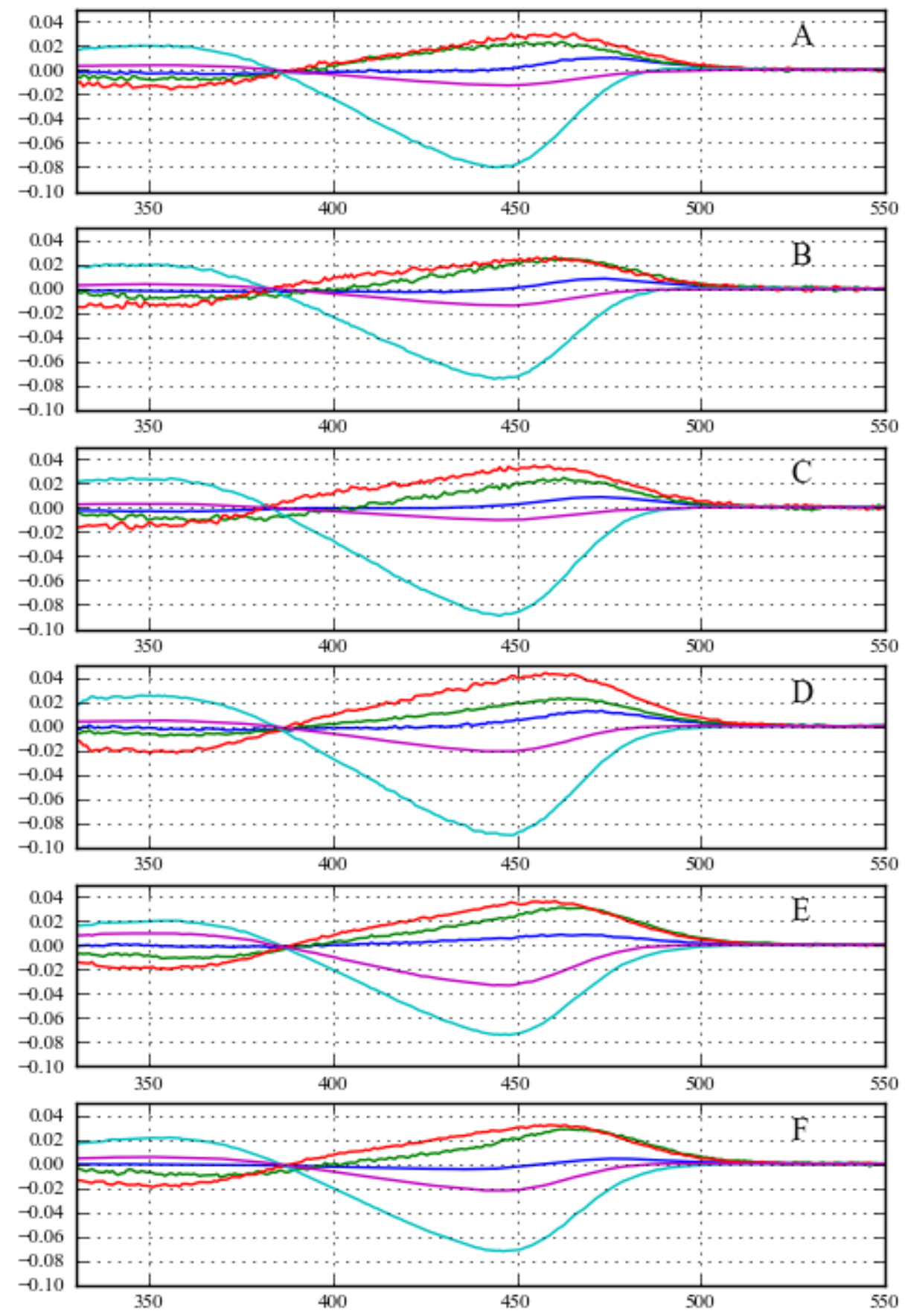

wavelengh, $(\mathrm{nm})$

Figure 4.17 B-spectra calculated from the SVD analysis and global multiexponential fit of different datasets. $A-\mathrm{NaCl} 50 \mathrm{mM}, \mathrm{B}-\mathrm{NaF} 0.66 \mathrm{M}, \mathrm{C}$ $\mathrm{NaCl} 0.66 \mathrm{M}, \mathrm{D}-\mathrm{NaNO}_{3} 0.66 \mathrm{M}, \mathrm{E}-\mathrm{NaI} 0.66 \mathrm{M}, \mathrm{F}-\mathrm{NaClO}{ }_{4} 0.66 \mathrm{M}, 22^{\circ} \mathrm{C}, \mathrm{pH}=8.2$. Blue, green, red, magenta and cyan represent spectra associated with the 1st, $2 n d$, $3 r d, 4$ th and 5th exponential transitions, respectively.

rate constant of $3.43 \times 10^{5} \mathrm{~s}^{-1}$ represents a spectrally minor transition between the first and a second red shifted intermediate, $\mathrm{pR}_{1}$ and $\mathrm{pR}_{2}$, represented mainly by the amplitude 
decrease. This agrees well with a similar transition between two red-shifted intermediates, reported to have a rate constant of $5.9 \times 10^{5} \mathrm{~s}^{-1}$ at $\mathrm{pH} 8.1$, low salt concentration and $20{ }^{\circ} \mathrm{C}$ (Hendriks et al., 2003). The second B-spectrum describes a transition of $4.0 \times 10^{3} \mathrm{~s}^{-1}$ between the red shifted intermediate(s) and an early blue shifted intermediate, $\mathrm{pB}_{1}$, with an expected absorption maximum close to $370 \mathrm{~nm}$. The third transition $\left(678 \mathrm{~s}^{-1}\right)$ accumulates another blue shifted intermediate, $\mathrm{pB}_{2}$, with a maximum close to $350 \mathrm{~nm}$. As it will be seen later, the positive signal in the range of $400 \mathrm{~nm}$ is the result of $\mathrm{pB}_{1}$ having a shoulder on its red side. The last two B-spectra corresponding to the rate constants of 2.28 and $0.18 \mathrm{~s}^{-1}$ represent the recovery of the parent dark state of PYP, pG. The fact that this is a biexponential process and that the shape of the two B spectra are very similar suggests that there is a spectrally silent intermediate, $\mathrm{pG}_{1}$ (with an absorption spectrum similar to the dark state) before the final recovery. Omitting the small amplitude $5^{\text {th }}$ exponential would mean that the amplitude of the signal at $6.5 \mathrm{~s}$ (spectrum no. 27) should drop to $\mathrm{e}^{-2.28 \times(6.5-0.2)}=5.8 \times 10^{-7}$ times the amplitude measured at $200 \mathrm{~ms}$ (spectrum no. 19). This does not hold, as the scaling factor to equalize the amplitudes of the $27^{\text {th }}$ and $19^{\text {th }}$ spectra is equal to $4 \times 10^{-2}$. The small amplitude $5^{\text {th }}$ exponential process is also evident in the measurements where recovery is faster, in the presence of high concentration of $\mathrm{NaF}$ or at low salt concentration.

\subsubsection{Target testing to determine the input intermediate spectra}

Extrapolated difference spectra were calculated from the $\mathbf{B}$ matrix, as described in the Materials and methods section. The generated matrix $\mathbf{B}^{\sim}$ is plotted in Figure 4.18 (bottom). The photocycling ratio together with the difference spectrum of $\mathrm{pB}_{2}$ were estimated using the target testing procedure in the $>430 \mathrm{~nm}$ spectral range (Joshi et al., 2006), since the absolute spectrum of $\mathrm{pB}_{2}$ is expected to have zero absorption in this region. A truncated $\mathbf{B}^{\sim}$ matrix was used during this procedure; the selected $1^{\text {st }}, 3^{\text {rd }}$ and $4^{\text {th }}$ columns of $\mathbf{B}^{\sim}$ are representative and sufficiently different to be linearly independent. The calculated spectrum of $\mathrm{pB}_{2}$ is shown in Figure 4.19 (top). The value of 0.175 was obtained for the photocycling fraction. Assuming that $\mathrm{pR}_{1}$ is the only intermediate present at $80 \mathrm{~ns}$ after sample excitation, and using the photocycling ratio from above, the spectrum of the first intermediate, $\mathrm{pR}_{1}$, was calculated. The spectrum of $\mathrm{pB}_{1}$ could be obtained by trial and error as in Joshi et al. (2006). In order to avoid negative absorption, the valid $\mathrm{pB}_{1}$ spectra obtained had a significant shoulder on their red side 


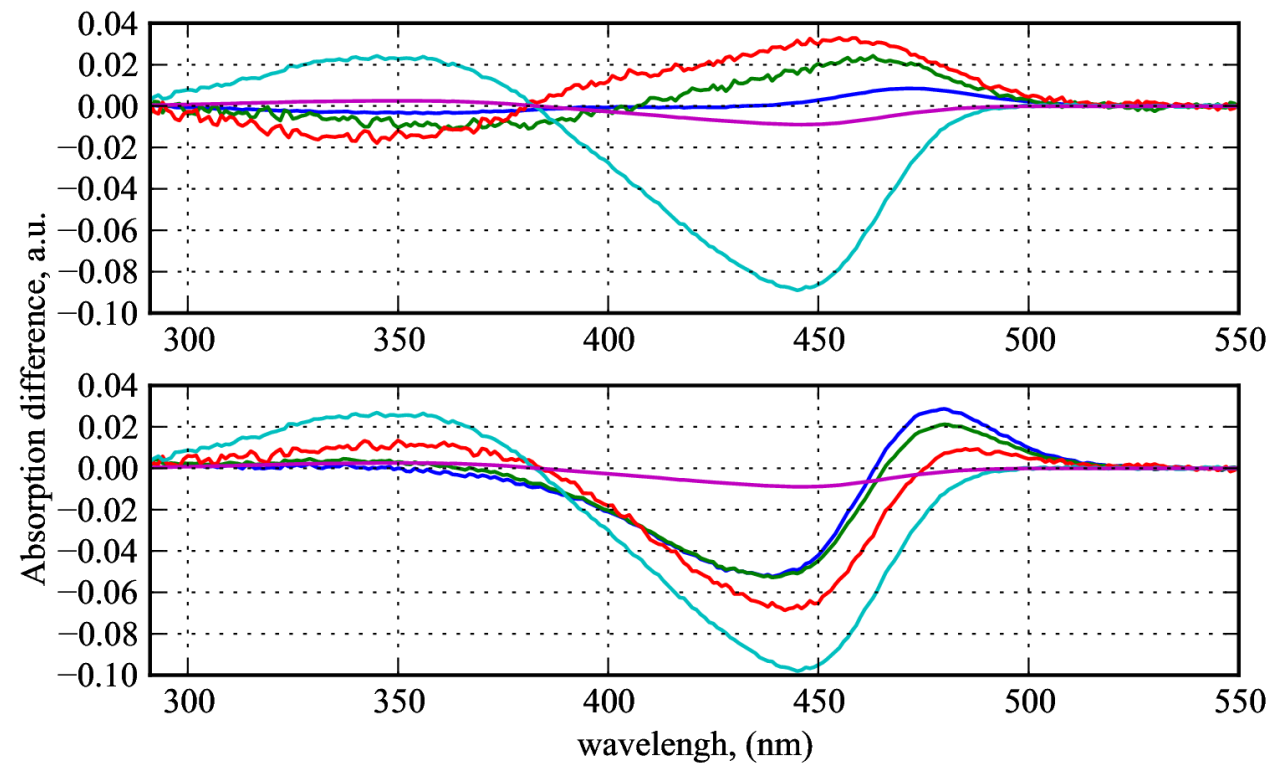

Figure 4.18 The columns of the $\boldsymbol{B}^{\sim}$ matrix (bottom) generated from matrix $\boldsymbol{B}$ (top), by summation (see sections 3.7); blue, green, red, cyan, purple are the $1^{s t}, 2^{\text {nd }}, 3^{\text {rd }}, 4^{\text {th }}, 5^{\text {th }}$ columns of $\boldsymbol{B}$ and $\boldsymbol{B}^{\sim}$.

(Figure 4.19, top). This shoulder, redolent of the $\mathrm{I}_{1}{ }^{\prime}$ intermediate present at even higher $\mathrm{pH}$, has been interpreted as the deprotonated form of $\mathrm{I}_{2}{ }^{\prime}$ in equilibrium with $\mathrm{I}_{2}{ }^{\prime}\left(\mathrm{pB}_{2}\right.$ in our notation) (Joshi et al., 2006). It is clear from our analysis that this shoulder belongs to the $\mathrm{pB}_{1}$ intermediate instead.

\subsubsection{The photocycle model}

The photocycle model has to account for all information obtained during the analysis preceding the model fitting: Five transitions with at least three independent spectra were necessary in the SVD and the global multiexponential fit. The data allowed to distinguish two $\mathrm{pR}$ intermediates, which are spectrally rather similar but different kinetically. The presence of a red shifted shoulder in the $\mathrm{pB}_{1}$ spectrum indicated its coexistence with its alkaline form. Visual inspection of the absolute spectra calculated from the measured difference spectra by addition of the absolute spectrum of $\mathrm{pG}$, scaled by the photocycling fraction, showed the dominance of the blue shifted intermediate(s) at the end of the photocycle, but also the presence of the early red shifted intermediate(s). This suggests that an equilibrium between intermediates was formed. Finally, to cope with the biexponential recovery of the dark state, a spectrally silent intermediate, $\mathrm{pG}_{1}$ was required at the end of the photocycle. The simplest (and also 
physically feasible) photocycle scheme, that takes into consideration the features listed above, is a sequential scheme involving the $\mathrm{pR}_{1}, \mathrm{pR}_{2}, \mathrm{pB}_{1}, \mathrm{pB}_{2}$ and $\mathrm{pG}_{1}$ intermediates (Figure 4.20), where the $\mathrm{pB}_{1}$ intermediate is represented as a mixture of alkaline and basic forms of the chromophore due to its transient deprotonation at moderately alkaline $\mathrm{pH}$. This scheme was therefore used in the subsequent global spectrotemporal model fit to the data matrix. The spectra of the intermediates depicted in the top panel of Figure 4.19 were used as initial guess. It must be emphasized that from this point on the analysis and the results do not depend on the method used to obtain the input "seed" spectra and photocycling fraction, except so much as a nonlinear least squares model fit can depend on the input parameters. The same spectrum has been used as initial guess for $\mathrm{pR}_{1}$ and $\mathrm{pR}$, but in the fitting procedure they were varied independently to obtain their distinct final shape. As described above, the spectrum of the postulated $\mathrm{pG}_{1}$ form was assumed to be identical to the dark state (pG) spectrum and kept constant. All molecular transitions except for the last one were set to be reversible. In case if any of the forward rates, estimated during the model fit, were many orders of magnitude larger than the corresponding reverse ones, then this step was identified as unidirectional. For
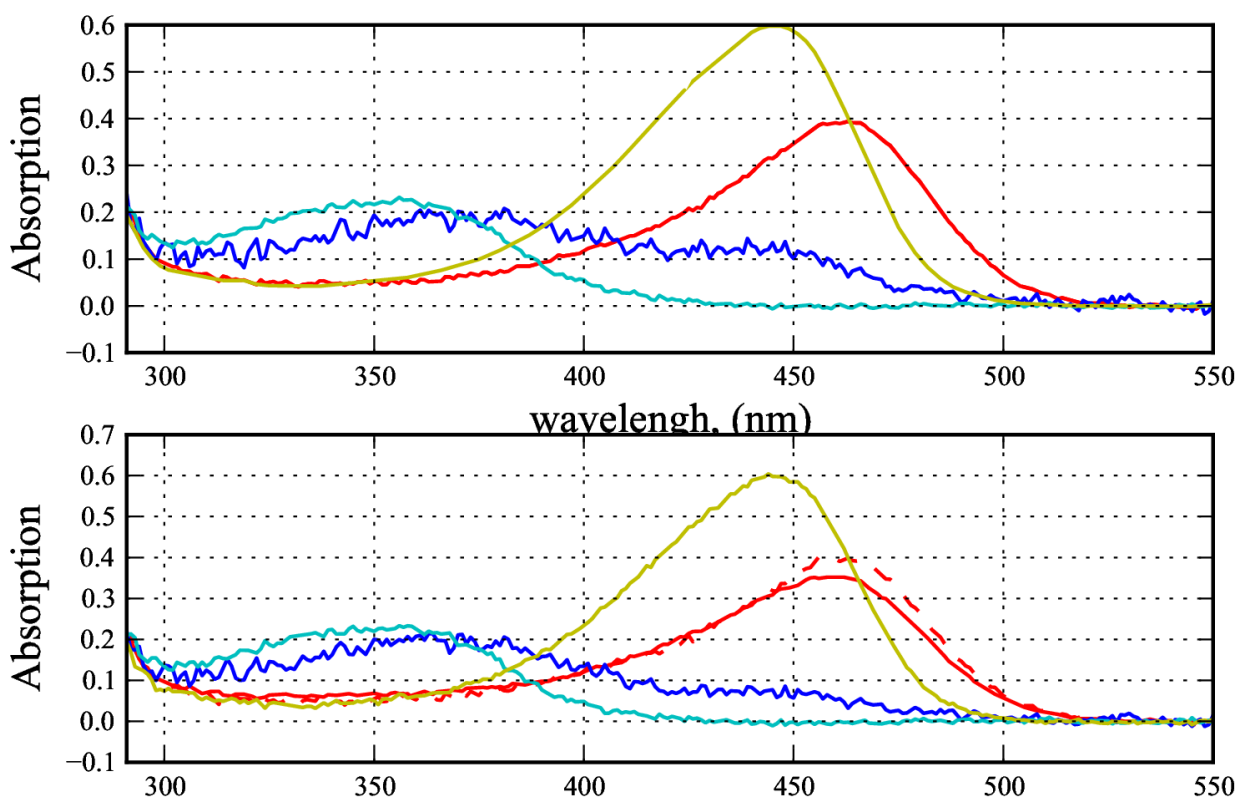

Figure 4.19: (top) Input intermediate spectra for the spectrotemporal model fit obtained from the $S V D$ - exponential fit - target testing and extrapolated difference method described in the data analysis section and in Joshi et. al. 2006 , red $-p R_{1}$ and $p R_{2}$, blue $-p B_{1}$, cyan $-p B_{2}$, yellow $-p G\left(p G_{1}\right)$. (bottom) Output intermediate spectra from the spectrotemporal model fit, $p R_{1}$ - red solid $p R_{2}$ - red-dashed, the rest as in the top panel. 


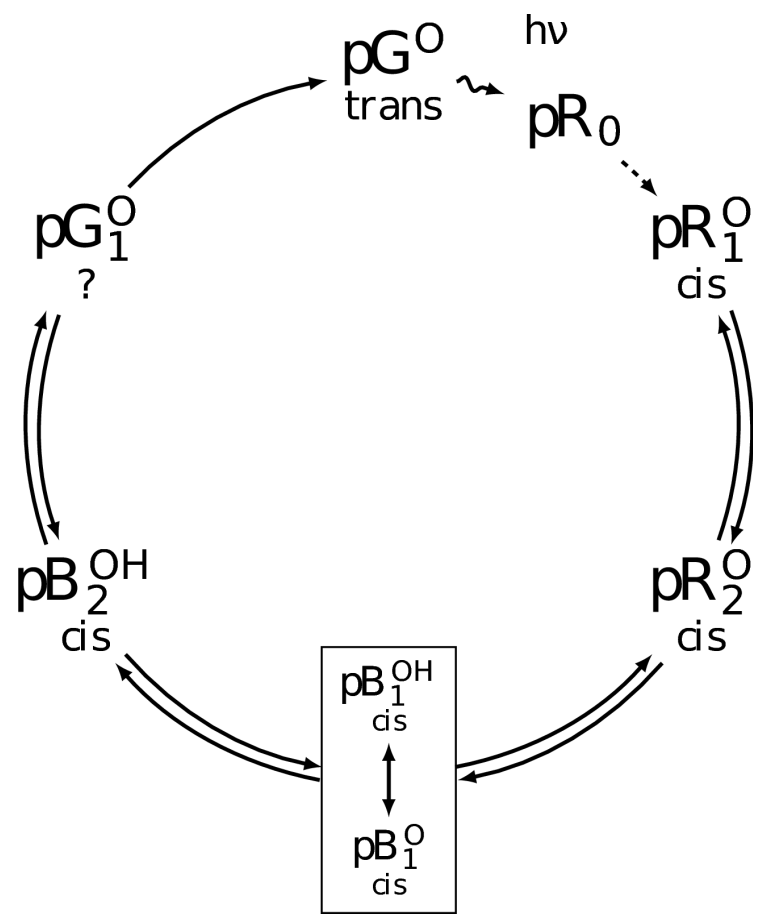

Figure 4.20 The proposed photocycle of PYP at moderately alkaline $p H$, used in the spectrotemporal model fit to the data. The isomerization state of the p-coumaric acid chromophore and the protonation state of its phenolic oxygen are shown. $p R_{0}$ designates early intermediate(s) not resolved in this study. The rapid protonation equilibrium mixture of the spectrally identified $p B_{1}$ forms is represented by the rectangular box.

the final recovery of the dark state the reverse reaction was not permitted, otherwise there would be a stationary accumulation of intermediate(s) upon photoexcitation, which was not observed and the protein, eventually, fully recovered to the dark state. Unidirectionality of the last step accounts for the necessity of a sufficiently large free energy drop in the last step, a reasonable assumption for a photosensory protein, which would also forbid thermal activation into the photocycle intermediates.

Using the output rate coefficients from the model fit the time course of the intermediates was calculated. This is plotted in Figure 4.21, while the corresponding intermediate absorption spectra are depicted in the bottom panel of Figure 4.19. The residuals of the fit, calculated as $\mathbf{D}-\mathbf{\varepsilon c}^{\mathbf{T}}$, can be seen in Figure 4.14. The transition between the two red shifted intermediates $\left(\mathrm{pR}_{1}\right.$ and $\left.\mathrm{pR}_{2}\right)$ appeared to be virtually unidirectional. The other intermediates, $\mathrm{pR}_{2}, \mathrm{pB}_{1}, \mathrm{pB}_{2}$ and $\mathrm{pG}_{1}$, are in equilibrium as a result of the reversibility of their interconversions, and decay together at the end of the photocycle. As expected, the estimated $\mathrm{pR}_{2}$ spectrum is similar in shape but slightly smaller in its amplitude, as compared to the spectrum of $\mathrm{pR}_{1}$. The spectrum of $\mathrm{pB}_{1}$, in 
Results
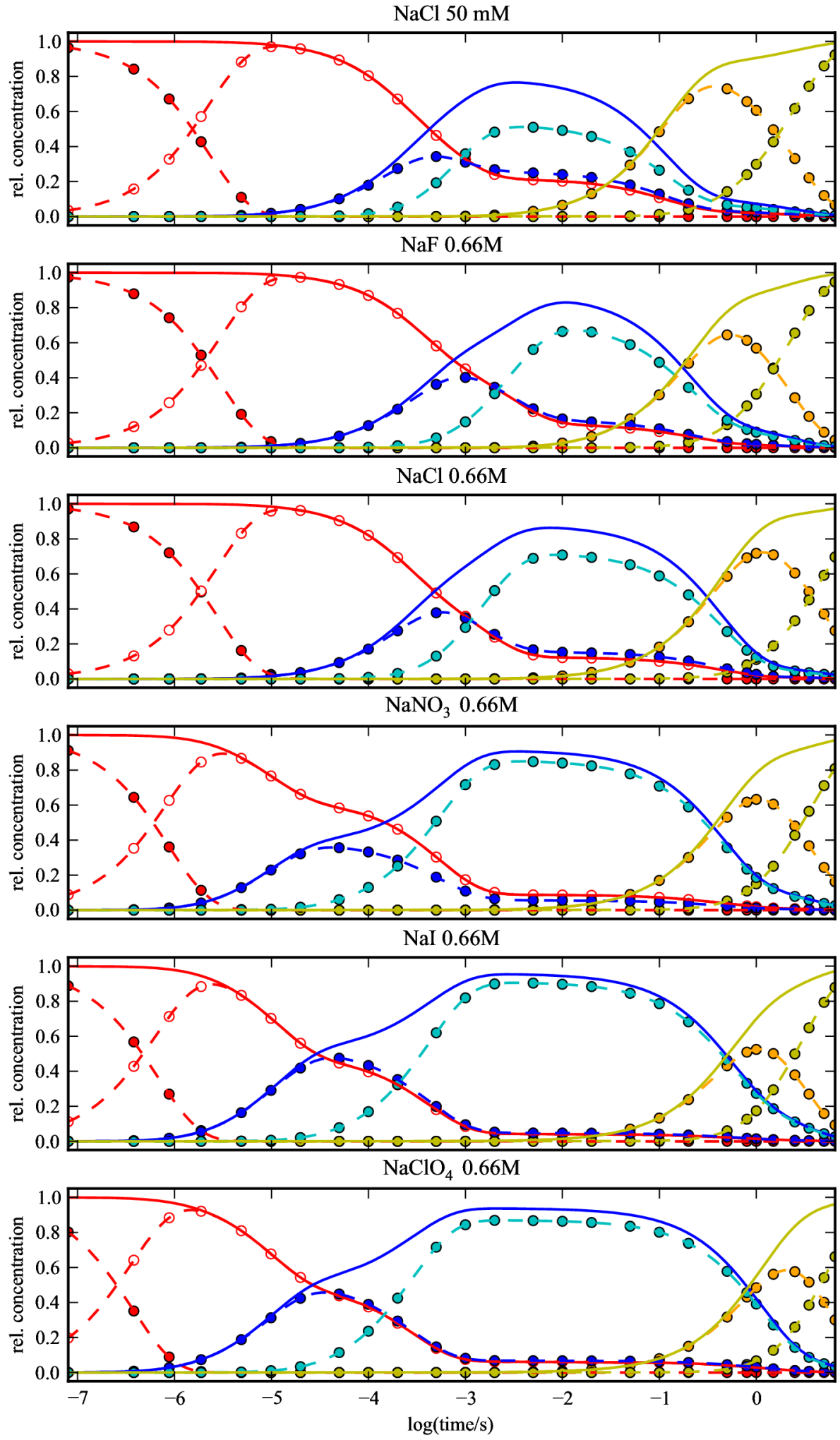

Figure 4.21 Relative concentrations of the intermediates during the photocycle, in different salt conditions. Legend: $p R_{1}-$ red circles, $p R_{2}$ - empty red circles, $p B_{1^{-}}$ blue circles, $p B_{2}$ - cyan circles, $p G_{1}$ - orange circles, $p G-$ yellow circles, solid red line - sum of $p R_{1}$ and $p R_{2}$, solid blue line - $p B_{1}+p B_{2}$, solid yellow line $p G_{1}+p G$. 
addition to the expected band of the protonated form with the maximum at about 370 $\mathrm{nm}$, exhibits a shoulder on its red side, symptomatic of the deprotonated form with a maximum estimated at appr. $450 \mathrm{~nm}$. We cannot kinetically resolve its formation and decay, in other words, it must be in a very rapid equilibrium with the main protonated $\mathrm{pB}_{1}$ species. Furthermore, from the analysis of our data we conclude that this form derives from the deprotonation of $\mathrm{pB}_{1}$ rather than that of $\mathrm{pB}_{2}$. The second blue shifted intermediate, $\mathrm{pB}_{2}$, with a maximum near $350 \mathrm{~nm}$, is present as a homogeneous, protonated population at this moderately alkaline $\mathrm{pH}$. It is also essential to clarify, that the formation of the deprotonated $\mathrm{pB}_{1}$ is not due to the reverse proton transfer from the chromophore to the proton donor group, E46, since that process is represented in the model by the well resolved reverse reaction $\mathrm{pR}_{2} \leftarrow \mathrm{pB}_{1}$.

\subsubsection{Intermediate kinetics as a function of cosolutes}

Data obtained at $50 \mathrm{mM} \mathrm{NaCl}, 0.66 \mathrm{M} \mathrm{NaF}, \mathrm{NaI}, \mathrm{NaNO}_{3}$ and $\mathrm{NaClO}_{4}$ have been subjected to similar examination. The analysis produced very similar spectra, apart from $\mathrm{pB}_{1}$ at low salt concentration, having a negligible contribution of its deprotonated form. However, the intermediate kinetics varied substantially (Figure 4.21). As it has been reported previously by Hoersch et al. (2007), the increase of ionic strength affects mainly the $\mathrm{pB}_{2}$ population, resulting in a shift of the $\mathrm{pB}_{1} / \mathrm{pB}_{2}$ equilibrium towards $\mathrm{pB}_{2}$, and causes a slower apparent decay of the latter. Both effects have been associated with the $\mathrm{K} 110 / \mathrm{E} 12$ salt bridge in $\mathrm{pB}_{1}$, which stabilizes this intermediate, and which is absent in the open conformation of $\mathrm{pB}_{2}$. Thus, screening the charges of the separated salt bridge in the $\mathrm{pB}_{2}$ intermediate makes the breaking of the salt bridge energetically less expensive at higher salt concentration. The dominant phenomenological effect of Hofmeiter salts manifested itself in the change of the time frame occupied by the total $\mathrm{pB}$ population during the photocycle. If compared to the Hofmeister-neutral $\mathrm{Cl}^{-}$, the presence of the kosmotropic anion $\mathrm{F}^{-}$leads to the delayed formation and accelerated decay of the total $\mathrm{pB}$ population, whereas the increasingly chaotropic anions $\mathrm{NO}_{3}^{-}, \mathrm{I}^{-}$ and $\mathrm{ClO}_{4}^{-}$cause the progressively opposite behaviour. In the chaotropes $\mathrm{pB}_{1}$ and $\mathrm{pB}_{2}$ are well resolved in time, as a result the total $\mathrm{pB}$ population rises in a characteristically biphasic way. The variation of the molecular rate coefficients as a function of the cosolute anion is plotted in Figure 4.22. The examination of the rates in high and low $\mathrm{NaCl}$ concentrations shows that the stabilization of the $\mathrm{pB}_{2}$ intermediate in high salt 
Results

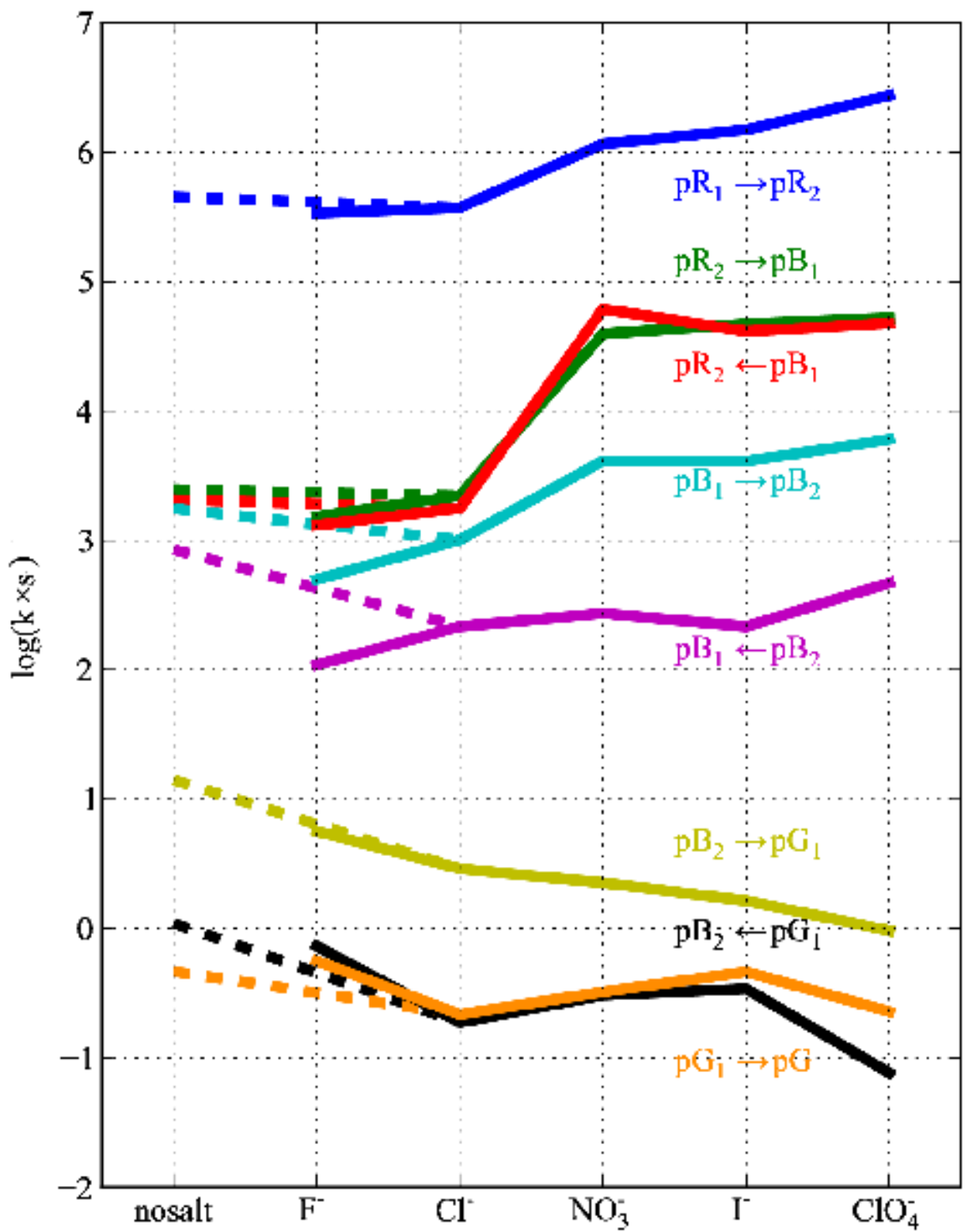

Figure 4.22 The dependence of the rate coefficients between intermediates on the cosolute salts.

concentration is a result of the deceleration of the two rate coefficients responsible for its depletion, $\mathrm{pB}_{1} \leftarrow \mathrm{pB}_{2}$ and $\mathrm{pB}_{2} \rightarrow \mathrm{pG}_{1}$. The rates depleting the $\mathrm{pG}_{1}$ exhibit similar behaviour. The HE at high concentrations of different anionic cosolutes shows up as the acceleration of the rates in the $\mathrm{pR}_{1} / \mathrm{pR}_{2} / \mathrm{pB}_{1} / \mathrm{pB}_{2}$ segment upon change from kosmotropes to chaotropes, while at the same time the rates of the further transitions $\left(\mathrm{pB}_{2} / \mathrm{pG}_{1} / \mathrm{pG}\right.$ segment) show rather a tendency of deceleration. The parallel acceleration of both 
forward and reverse rates of the $\mathrm{pR}_{2} \leftrightarrow \mathrm{pB}_{1}$ transitions leads to the accelerated formation of $\mathrm{pB}_{1}$, while the $\mathrm{pR}_{2} / \mathrm{pB}_{1}$ equilibrium remains unaffected. Curiously, these transitions happen to be the most affected by the Hofmeister cosolutes. The acceleration of transitions between $\mathrm{pB}_{1}$ and $\mathrm{pB}_{2}$ by increasingly more chaotropic cosolutes is manifested to a lesser extent. 


\section{Discussion}

\subsection{TUPS photochemistry}

The species we identify as the reduced (negative) radical of TUPS is characterized by a difference spectrum in shape much like that of the anionic radical for 1 pyrenesulfonate (Mori et al., 2002a, b), formed upon its recombination with hydrated electrons. The absorption maximum of the 1-pyrenesulfonate anionic radical is at 490 $\mathrm{nm}$, which is blue shifted by $18 \mathrm{~nm}$ from the maximum of the TUPS-reduced radical what we observe here. The difference may be due to the combined effect of the sulfate and thiouredo substituents on the spectrum of TUPS-. This is in accordance with the observed peak positions of the triplet absorption at 420 and $430 \mathrm{~nm}$, respectively, for 1pyrenesulfonate and 1,3,6,8-pyrenetetrasulfonate, and the peak positions of the cationic radicals of these molecules at 457 and $505 \mathrm{~nm}$, respectively (Mori et al., 2002a, b; Mori et al., 2003).

Our proposed model of the TUPS triplet interactions in the presence of $\mathrm{KCl}$ describes the experimental data well. The first order rate constant for triplet decay agrees well with reported values (Kotlyar et al., 1997a), and the bimolecular rate constants are typical for diffusion-limited processes. Triplet-triplet annihilation (Turro, 1978) is an essential component of our suggested scheme. Models which did not take it into account were not able to reproduce the kinetics of the positive and negative radicals, and the $\sigma$ of the overall fit to the kinetics was $2.05 \times 10^{-7}$, as compared to the $\sigma=1.36 \times 10^{-7}$ of the fit by the complete model shown on page 30 . The possibility of geminate charge recombination (Turro, 1991) within the solvent cage immediately after the formation of TUPS $^{+}$and TUPS ${ }^{-}$cannot be ruled out either. This process can be concealed in the total rate of triplet-triplet annihilation and, actually, may be behind the relatively low amount of TUPS $^{+}$and TUPS- detected experimentally (Figure 4.5). Another model with electron transfer between a triplet and a ground state TUPS molecule (rather than two triplets) can also be suggested. But the inclusion of this assumption yielded a slightly worse fit than did the model with triplet-triplet electron transfer $\left(\sigma=1.61 \times 10^{-7}\right)$, eliminating, in addition, the triplet decay by phosphorescence or inter-system crossing. This contradicts the observation that the triplet decay time 
constant is expected to be about half millisecond, as measured at lower TUPS concentrations and in the absence of salt.

\subsection{Electron transfer in singly labelled TUPS-cytochrome c derivatives}

The photoinduced electron transfer between TUPS and the heme of cytochrome $c$ proved to be more complicated than predicted on the basis of Marcus' theory. While, at the available signal to noise ratio, forward electron transfer appears roughly monoexponential, the reverse electron transfer clearly does not. The multiexponential behaviour can be explained by sample heterogeneity, which is, in fact, corroborated by the results of MD simulations. MD results show that the TUPS label is likely to occupy several geometrically feasible equilibrium positions, with different effective distances from the heme, and various packing densities between cofactors. In these experiments, as seen from kinetic spectroscopy measurements, there is an initial, unresolved reduction in a small fraction of the hemes (Figure 4.10). It is not likely due to one of the populations characterized by a certain TUPS conformation, as the forward electron transfer is not supposed to be so fast. One explanation could be the production of solvated electrons by the laser flash, as it happens during pyranine photo-oxidation (Kotlyar et al., 1996). The solvated electrons could rapidly reduce nearby cytochrome $c$ molecules, leaving behind the positive radical of TUPS. Such an effect could also explain the finding that a small amount of "permanently" reduced cytochrome $c$ seems to accumulate after each laser flash, reflected by the positive baseline necessary to fit the experimental kinetics. Yet, the magnitude of these effects is small enough, not to interfere with the major conclusions drawn. As suggested from MD calculations, a number of non-interconvertible equilibrium TUPS conformations are present under the modeled conditions. Multiexponential electron transfer behaviour can only appear in a heterogeneous sample if the subpopulations do not mix on the time scale of the electron transfer, otherwise rapid interconversions would result in an average single exponential process. By the same token, protein moiety conformational heterogeneity (conformational substates) would be an implausible explanation of the observed electron transfer heterogeneity at room temperature. The above considerations have brought about the assumption that the label occupies several distinct positions close to the protein surface and thereby forms well defined stationary subpopulations, stable on 
the microsecond-millisecond time scale. The estimated electron transfer parameters differ between subpopulations and can qualitatively explain the observed rate constants. 1HRC.pdb X-ray structure was selected as a starting point for the MD calculations, because of its high resolution and the availability of water molecules in it. Excluding cytochrome $c$ complexes with enzymes, there are, altogether, nine available PDB entries for this protein. Most of the structures were resolved using the NMR technique. Sixty NMR structures presented in 2 files exhibit a certain limited conformational variability. All are slightly different from the selected X-ray structure, however, the backbone root mean square deviation between 1HRC and the other structures averages at $1.88 \AA$ and does not exceed $2.55 \AA$. Given this, it is safe to accept $1 \mathrm{HRC}$ as a typical cytochrome $c$ structure even in an aqueous solution. Sterically allowed rearrangements of the TUPSlinker moiety, found in our calculations, are substantially bigger than the fluctuations in the protein structure. For this reason the MD calculations, aimed at locating possible TUPS positions relative to the protein surface, which are allowed by the covalent link between the two, should at least qualitatively be informative even though the motion of the protein moiety (other than the side chain of Cys 8 ) was not allowed.

Intraprotein electron transfer proceeds via covalent bonds, hydrogen bonds, and through space jumps, in this order of efficiency. Water molecules may facilitate intraand interprotein electron transfer (de la Lande et al., 2010), by filling in cavities within and between proteins and providing additional hydrogen bridges. To check this possibility, optimal electron transfer pathways were calculated for the four MDcalculated TUPS-protein conformations solvated in silico and with the structural water molecules from X-ray included. Inclusion of water has not altered the calculated optimal pathways, in other words, no water molecules were found in position appropriate to generate a path with better coupling. This is not surprising, taking into account that the system under investigation is rather compact and the redox cofactors are placed fairly close to each other. Addition of water resulted in a slight increase of packing density, and better electronic coupling ( $6 \%$ increase) and higher expected rate constants (13\% increase). These changes are, however, negligible when compared to the sensitivity of electron transfer rates to other factors, such as small variations in distance. The qualitative picture emerging from our MD and electron transfer calculations is promising. It must be mentioned, nonetheless, that the implicit water representation by 
the homogeneous dielectric medium is a simplification. It accentuates ionic interactions, while other potential factors such as hydration and solvation effects are neglected.

\subsection{PYP photocycle at moderately alkaline $\mathrm{pH}$ and its modulation by $H E$}

Since the discovery of PYP, numerous mechanisms of varying complexity have been proposed for its photocycle, depending on the available time resolution, the sample condition, as well as the employed experimental method (spectroscopic or structural). Published models differ in the number of considered intermediates and the reversibility/irreversibility of transitions between them. Consequently, the structural and functional interpretation of the intermediates and the kinetics and energetics of the reaction cycle also differ. Here we adopted the moderate $\mathrm{pH}$ branch of the complex model of Hendriks and Hellingwerf (2009), i.e. the scheme proposed for the $\mathrm{pH}$ range between 4.1 and 10.0 (see their figure 9) with some modifications. Our model includes an additional red shifted intermediate, $\mathrm{pR}_{2}$, between $\mathrm{pR}_{1}$ and $\mathrm{pB}_{1}(\mathrm{pR}$ and $\mathrm{pB}$ ' in their notation) and allows a reverse transition from $\mathrm{pB}_{2}$ to $\mathrm{pB}_{1}\left(\mathrm{pB}^{\prime}\right.$ and $\mathrm{pB}$ in their notation). $\mathrm{pR}_{0}$ refers to sub-nanoseconds intermediates, which are not accessible at the time resolution used in our experiments and therefore they are not taken into account. Our photocycle scheme also integrates the two schemes given in Hendriks et al. (2003), and it is similar to the detailed model depicted in figure 4 of the review by Hellingwerf et al. (2003). The proposed model differs from the one mentioned above in the reversibility of the $\mathrm{pB}_{1}$ to $\mathrm{pB}_{2}$ transition. This reversibility has been convincingly proven experimentally by the group from Berlin, who have shown mutual interconversion between $\mathrm{pB}_{1}$ and $\mathrm{pB}_{2}$, and the resulting thermal equilibrium between the two blue shifted intermediates ( $\mathrm{I}_{2}$ and $\mathrm{I}_{2}{ }^{\prime}$ in their notation), observed in single and double flash absorption kinetic experiments (Joshi et al., 2005; Borucki et al., 2006; Joshi et al., 2006; Hoersch et al., 2007).

By means of pump-probe Laue-crystallography on PYP crystals the structure of several photocycle intermediates with atomic spatial resolution has been determined (Schmidt et al., 2004; Ihee et al., 2005; Schotte et al., 2012; Tripathi et al., 2012). However, due to steric constraints imposed on the protein in the tightly packed crystal, the photocycles in solution and in crystal cannot be compared directly (Heberle and 
Gensch, 2001). Altered kinetics of the intermediates in crystals as compared to those in solution were reported. They include, for example, an early partial recovery of the dark state via a branching reaction. Moreover, the formation of the partiality unfolded signalling state $\mathrm{pB}_{2}$ in crystals is absent, as the conformational change preceding it is completely inhibited (Yeremenko et al., 2006; Schotte et al., 2012; Tripathi et al., 2012). Yeremenko et al. (2006) performed a detailed comparison of the PYP photocycle in solution and in single crystals for wild type and E46Q mutant proteins. Data were measured in slightly acidic or neutral conditions and could be fitted by a simple sequential model, similar to ours, except for the unidirectionality of the transitions from $\mathrm{pB}_{1}$ onwards. Although these authors included $\mathrm{pR}_{1}$ and $\mathrm{pG}_{1}$ ( $\mathrm{pB}^{\text {deprot }}$ in their notation) in their model based on literature evidence, in their fit to the solution data these were omitted due to insufficient resolution. While the wild type photocycle in the crystal exhibited two consecutive red shifted and two consecutive blue shifted intermediates as in solution, their absorption spectra were different (and there was no blue shift going from $\mathrm{pB}_{1}$ to $\mathrm{pB}_{2}$ ). Furthermore, the temporal evolution of the intermediates was dramatically different. The total $\mathrm{pB}$ intermediate had shown a slower formation combined with a substantially faster decay in the crystal as compared to solution. The early appearance of the $\mathrm{pB}_{1}$ intermediate could be best fitted by parallel branches containing the two $\mathrm{pR}$ forms and the early and biphasic $\mathrm{pG}$ recovery by a shortcut from $\mathrm{pB}_{1}$ to $\mathrm{pG}$. Despite all these deviations, the consecutive intermediate structures recorded after the photoexcitation of PYP in the crystal are very instructive in the interpretation of the events during the photocycle in solution, from the chromophore isomerization to the signaling state formation, particularly in the chromophore surroundings. The chromophore before excitation is stabilized in trans-conformation by three hydrogen bonds: between the phenolic oxygen and the Tyr42 and Glu46 side chains, and between the backbone nitrogen of Cys69 and the carboxylic oxygen. Absorption of a blue photon initiates a bicycle-pedal type isomerization and, as a result, the H-bond with Cys69 breaks up, while the phenolic oxygen remains hydrogen bonded to Tyr42 and Glu46, or at least to Tyr42. Such an arrangement represents the typical structure for the $\mathrm{pR}$ state. The crystalline $\mathrm{pB}$ state is apparently equivalent to the $\mathrm{pB}_{1}$ form in solution. Upon its formation, as demonstrated by time-resolved FTIR experiments (Brudler et al., 2001), the phenolic group of the p-coumaric acid should be protonated and the carboxylic 
group of Glu46 deprotonated. The isomerized and relaxed chromophore is now positioned away from Glu46 and Tyr42 and a new H-bond forms with Arg52. The sidechain of the latter amino acid is displaced, resulting in an open chromophore pocket and the exposure of the chromophore to the solvent. Two new water molecules show up in the structure at this stage. One is H-bonded between Glu46 and Tyr42, another one between the phenyl hydroxyl and the protein backbone. It has been suggested that the former two hydrogen bonds constitute the kinetic barrier to the chromophore reisomerization, thereby allowing an efficient signalling function by extending the photocycle to the time domain of seconds (Schotte et al., 2012).

The assumption of reversibility is a natural choice to be borne out or excluded by the fit of the data. The exception is the last step of the photocycle, because the recovery to the dark state is complete. As a matter of fact, the rate coefficients obtained for the $\mathrm{pR}_{1} \leftarrow \mathrm{pR}_{2}$ reverse reaction appeared to be several orders of magnitude smaller than the rates of the forward reaction, indicating the unidirectionality of this process (but not the others). The little spectral difference between $\mathrm{pR}$ intermediates is likely due to a structural change in the chromophore pocket while it accommodates the isomerized chromophore, as demonstrated also by time-resolved optical rotatory dispersion (Chen et al., 2003). Despite the success of the proposed model, because of the limited time resolution and small magnitude of spectral change, we cannot rule out completely the possibility of reversibility or even of the two $\mathrm{pR}$ intermediates forming in parallel on nanoseconds timescale.

The analysis of data in section 4.4 led us to the conclusion that at $\mathrm{pH} 8.2$ and high salt concentration the $\mathrm{pB}_{1}$ intermediate is a fast unresolved equilibrium mixture of two populations with different protonation states of the phenolic oxygen of the chromophore or, possibly, with various hydrogen bonding strength within the chromophore pocket. The successful model fit with this mixture spectrum further corroborated this assumption. The consecutive transition from $\mathrm{pB}_{1}$ to $\mathrm{pB}_{2}$ in solution - which is not observed in the crystal - is coupled to the major conformational change and accompanied by the further blue shift in the intermediate spectrum. Such effect may be due to stronger hydrogen bonding or increased hydration of the chromophore. The latter, according to quantum chemical calculations, may result in the approximately $15 \mathrm{~nm}$ further blue shift of the absorption maximum. 
As was revealed by earlier experimental studies with Hofmeister-active ions, they do have an impact on some structural and dynamical properties of PYP. The hydrogen bond network around the p-coumaric acid is affected by chaotropic and kosmotropic salts. The effect was demonstrated for wild type and several Y42x mutants. Upon increase of the concentration of the chaotropic agent or guanidine hydrochloride, a secondary blue shifted band gradually developed in the stationary absorption spectrum. Its relative contribution decreased in increasing concentrations of kosmotropic ions. In our study the absorption spectrum of the dark state did not vary with the type of cosolute, as we used substantially lower concentrations, then the concentrations required to induce the secondary band in the wild type protein. Y42 residue mutants demonstrate increased stability of the $\mathrm{pB}_{2}$ form. Its decay is slower while its formation is faster relative to wild type. The explanation of the blue shifted side-band (at $391 \mathrm{~nm}$ ) in the spectrum of the dark state by a population with partially protonated chromophore is reminiscent of the red shifted side band in the spectrum of wild type $\mathrm{pB}_{1}$ reported here. Presumably it is corresponding to a population in an intermediate conformation having a disturbed hydrogen bond network as compared to the dark state and with (partially) deprotonated chromophore. In addition, chaotropic anions have been found to shift the $\mathrm{pB}_{1} / \mathrm{pB}_{2}$ equilibrium in favour of $\mathrm{pB}_{2}$ (Hoersch et al., 2007).

We have employed HE to identify all transitions of the PYP photocycle that may be associated with major conformational changes. The phenomenological theory of HE by Dér (Dér et al., 2007; Dér, 2008) predicts the strongest effect of the Hofmeister salts on the rates of reactions involving large-scale water-exposed surface area changes. From the curves in Figure 4.21 an obvious duty cycle prolongation of the total $\mathrm{pB}$ form of PYP in chaotropic salts can be seen. While being considerably longer than that in the Hofmeister-neutral $\mathrm{NaCl}$ (taken as a reference), it is slightly shorter for PYP in the presence of the kosmotropic NaF. According to Dér et al. (2007), this implies stabilization of the conformationally more open $\mathrm{pB}$ forms by chaotropes, contrary to the kosmotropic $\mathrm{NaF}$ that seems to destabilize them. Indeed, extensive conformational changes accompanying the formation of the signalling state of the protein have been postulated previously. Using a range of experimental approaches a transient opening of the two main hydrophobic parts of the protein has been brought to light (van der Horst et al., 2001; Xie et al., 2001; Harigai et al., 2003; Harigai et al., 2008). First, the PAS 
core together with the $\beta$-scaffold adjusts to accommodate the chromophore, and then a reorganization of two helical segments in the $\mathrm{N}$-terminal domain occurs. By means of FTIR spectroscopy the $\mathrm{pB}$ form has been decomposed to two substates $\left(\mathrm{pB}_{1}\right.$ and $\left.\mathrm{pB}_{2}\right)$, and it has been established that the protonation of the chromophore precedes the major conformation change (Xie et al., 2001). Accordingly the $\mathrm{pR}_{2} \rightarrow \mathrm{pB}_{1}$ transition has been associated with the chromophore protonation, while the $\mathrm{pB}_{1} \rightarrow \mathrm{pB}_{2}$ transition is accompanied by a major conformational change in the $\beta$-scaffold domain of the protein. In light of these facts, $\mathrm{pB}_{2}$ is usually considered to be the signalling state. After performing the model fit to our data, the determination of the molecular rate coefficients provided more quantitative information, allowing to decipher the HE on the individual transitions of the photocycle (Figure 4.22). While an opening of the protein conformation during $\mathrm{pB}_{1} \rightarrow \mathrm{pB}_{2}$ is in good agreement with our results, we have also pinpointed additional opening processes. These are hinted at by the monotonic acceleration of the rates while the salt cosolute changes from kosmotropes to chaotropes. The early $\mathrm{pR}_{1} \rightarrow \mathrm{pR}_{2}$ transition already exhibits such behaviour and, surprisingly, far the biggest effect is associated with the $\mathrm{pR}_{2} \rightarrow \mathrm{pB}_{1}$ transition. Following Dér et al. (2007), we can conclude that in addition to the chromophore protonation, a conformation change associated with the exposure of hydrophobic residues of the protein should take place during this step. The relatively recently observed increase of the diffusion coefficient of PYP in the same time domain fully supports this conclusion (Hoshihara et al., 2008). These authors attributed the corresponding conformational change to the unfolding of the N-terminal domain. Time resolved FTIR spectroscopy experiments have also demonstrated major changes in the protein amide I bands already associated with this transition (Brudler et al., 2001). Notedly, the free energy difference between $\mathrm{pR}_{2}$ and $\mathrm{pB}_{1}$ does not seem to change significantly from chaotropes to kosmotropes. This follows from the fact that the salt dependence of the rate of the back reaction follows that of the forward process (Figure 4.22), so the stabilization of $\mathrm{pB}_{1}$ against $\mathrm{pR}_{2}$ is probably due to stochastic fluctuations of the energy barrier under the influence of cosolutes, as described in Neagu et al. (2001). In the $\mathrm{pB}_{1} \leftrightarrow \mathrm{pB}_{2}$ reaction, on the other hand, the equilibrium shifts towards $\mathrm{pB}_{2}$, in agreement with (Hoersch et al., 2007). Combining our results together with the relevant data of the literature, we suggest the following scenario during the PYP photocycle 
Discussion

(after the formation of $\mathrm{pR}_{1}$ ):

$$
\mathrm{pR}_{1} \rightarrow \mathrm{pR}_{2} \text { : conformational relaxation (opening) after isomerization }
$$

$\mathrm{pR}_{2} \rightarrow \mathrm{pB}_{1}$ : large-scale conformational opening with exposure of hydrophobic residues to the water (unfolding of the $\mathrm{N}$-terminal domain, coinciding with the protonation of the chromophore)

$\mathrm{pB}_{1} \rightarrow \mathrm{pB}_{2}$ : further conformational opening (changes in the PAS core and the $\beta$ scaffold)

$\mathrm{pB}_{2} \rightarrow \mathrm{pG}_{1}$ : conformational refolding (coinciding with the deprotonation of the chromophore)

$\mathrm{pG}_{1} \rightarrow \mathrm{pG}$ : reisomerization of the chromophore, final refolding to terminate the photocycle. 


\section{Conclusions}

We have shown that the photoactive redox dye, TUPS, can operate both as an electron donor and as an electron acceptor in its triplet excited state.

The demonstration of the oxidizing activity of TUPS ${ }^{*}$ opens the possibility to using this covalent redox label not only in the reductive, but also in the oxidative direction to study intra- and interprotein electron transfer.

We demonstrated the homogeneous electron exchange between excited TUPS molecules in solution and provided a kinetic scheme consisting of spontaneous triplet decay, of triplet- triplet annihilation, and of the electron transfer between TUPS molecules and its reverse.

The observed multiexponentiality of the electron transfer between the TUPS triplet and the heme of cytochrome $c$ cannot be directly derived from the Marcus theory of electron transfer. In addition, the electron transfer rate did not correlate with the geometric or chemical distance from the labelled (lysine or cysteine) amino acids to the heme.

An explanation for such deviation and multiexponentiality is given based on results of MD simulations. It appears that the optimal electron transfer does not fully follow the covalent link of TUPS along the labelled side chain, but involves most likely a through space jump from the surface of the protein directly to the ring structure of TUPS. We propose the presence of different TUPS conformations, stable on the timescale of the electron transfer process, as an explanation for the multiexponential behaviour.

Analysis of the PYP photocycle with a combination of chemometric methods and model fitting yielded acceptable intermediate spectra within the framework of a photocycle model which unites pieces of information from the published work of different groups.

It has also yielded kinetic information on the PYP photocycle with consistent, systematic salt-dependence. Chaotropes stabilize, kosmotropes destabilize the conformationally open $\mathrm{pB}$ forms, and the Hofmeister effect is strongest in the $\mathrm{pR}_{2} \rightarrow \mathrm{pB}_{1}$, transition, rather than in $\mathrm{pB}_{1} \rightarrow \mathrm{pB}_{2}$. 
The formation of the structurally open signalling state of PYP, therefore, takes place gradually, in 3 steps. 


\section{Acknowledgements}

Without any doubt, the most sincere thanks are reserved for my supervisor Prof. László Zimányi, who gave me the possibility to work in his laboratory, shared his knowledge and experience. During the whole time he provided moral support, friendship and guided me with never-ending patience.

I would like to express my gratitude to Dr. Katalin Tenger (Kati), with whom I had the pleasure to work in the same lab during my stay in Szeged and who had done the molecular biology part of the work used in this thesis, and to Dr. Gábor Rákhely for the careful supervision and support of the genetic engineering involved. Special thanks are due to Prof. Alexander Kotlyar and Dr. Natalie Borovok for their hospitality during my stay in their lab and also for providing the TUPS lysine derivative and lysine labelled cytochrome $c$ - TUPS complexes. I am thankful to Dr. Balázs Leitgeb who performed molecular dynamics simulations, and to Drs. John Fitch, Terry Meyer and Jos van Beeumen who generously provided the photoactive yellow protein sample. It is impossible not to mention Prof. András Dér, our collaborator and enjoyable lab neighbour, constructive discussions with whom I greatly appreciate.

I am grateful to the Hungarian Academy of Sciences and to the Institute of Biophysics of the Biological Research Centre, and especially indebted to Prof. Pál Ormos, General Director of the BRC and Director of the Institute, for his continuous professional and financial support during my studies.

My stay in Szeged would not have been the same without numerous personal interactions, short and long, professional and outside of work. I would like to thank to all colleagues from the Biological Research Centre and the Institute of Biophysics for their invaluable help and warm atmosphere they created. Special thanks are also due to members of the Photosynthesis group in the Institute of Plant Biology of the BRC and to Prof. Győző Garab, the group leader, for their support, for valuable scientific discussions and for their friendship.

Last but not least, I thank to my family, for their support, love and understanding. Special thanks to my wife, Csilla, who is the greatest discovery I have made. 


\section{References}

Ambler, R.P. (1991) Sequence variability in bacterial cytochromes c. Biochim Biophys Acta, 1058, 42-47.

Baca, M., Borgstahl, G.E., Boissinot, M., Burke, P.M., Williams, D.R., Slater, K.A., and Getzoff, E.D. (1994) Complete chemical structure of photoactive yellow protein: novel thioester-linked 4-hydroxycinnamyl chromophore and photocycle chemistry. Biochemistry, 33, 14369-14377.

Balabin, I.A., and Onuchic, J.N. (2000) Dynamically controlled protein tunneling paths in photosynthetic reaction centers. Science, 290, 114-117.

Banci, L., Bertini, I., Rosato, A., and Varani, G. (1999) Mitochondrial cytochromes $c$ : a comparative analysis. J Biol Inorg Chem, 4, 824-37.

Bechtold, R., Kuehn, C., Lepre, C., and Isied, S.S. (1986) Directional electron transfer in ruthenium-modified horse heart cytochrome $c$. Nature, 322, 286-288.

Berg, J., Tymoczko, J., and Stryer, L., (2006) Biochemistry. New York: WH Freeman and Company.

Bernard, C., Houben, K., Derix, N.M., Marks, D., van der Horst, M.A., Hellingwerf, K.J., Boelens, R., Kaptein, R., and van Nuland, N.A. (2005) The solution structure of a transient photoreceptor intermediate: Delta25 photoactive yellow protein. Structure, 13, 953-62.

Bertini, I., Cavallaro, G., and Rosato, A. (2006) Cytochrome $c$ : occurrence and functions. Chem Rev, 106, 90-115.

Bjerrum, M.J., Casimiro, D.R., Chang, I.J., Bilio, A.J.D., Gray, H.B., Hill, M.G., Langen, R., Mines, G.A., Skov, L.K., and Winkler, J.R. (1995) Electron transfer in ruthenium-modified proteins. J Bioenerg Biomembr, 27, 295-302.

Boelens, R., Wever, R., and Van Gelder, B. (1982) Electron transfer after flash photolysis of mixed-valence carboxycytochrome $c$ oxidase. Biochimica et Biophysica Acta (BBA)-Bioenergetics, 682, 264-272.

Borgstahl, G., Williams, D., and Getzoff, E. (1995) 1.4. ANG. Structure of Photoactive Yellow Protein, a Cytosolic Photoreceptor: Unusual Fold, Active Site, and 
Chromophore. Biochemistry, 34, 6278-6287.

Borucki, B., Joshi, C.P., Otto, H., Cusanovich, M.A., and Heyn, M.P. (2006) The transient accumulation of the signaling state of photoactive yellow protein is controlled by the external pH. Biophys J, 91, 2991-3001.

Brudler, R., Rammelsberg, R., Woo, T.T., Getzoff, E.D., and Gerwert, K. (2001) Structure of the I1 early intermediate of photoactive yellow protein by FTIR spectroscopy. Nat Struct Biol, 8, 265-70.

Bushnell, G.W., Louie, G.V., and Brayer, G.D. (1990) High-resolution threedimensional structure of horse heart cytochrome $c$. J Mol Biol, 214, 585-95.

Cacace, M.G., Landau, E.M., and Ramsden, J.J. (1997) The Hofmeister series: salt and solvent effects on interfacial phenomena. Q Rev Biophys, 30, 241-277.

Chen, E., Gensch, T., Gross, A.B., Hendriks, J., Hellingwerf, K.J., and Kliger, D.S. (2003) Dynamics of protein and chromophore structural changes in the photocycle of photoactive yellow protein monitored by time-resolved optical rotatory dispersion. Biochemistry, 42, 2062-2071.

Chothia, C., and Lesk, A.M. (1985) Helix movements and the reconstruction of the haem pocket during the evolution of the cytochrome $c$ family. J Mol Biol, 182, 1518.

Clark, M., Cramer III, R., and Van Opdenbosch, N. (1989) Validation of the general purpose Tripos 5.2 force field. Journal of Computational Chemistry, 10, 9821012.

Collins, K., Washabaugh, M., and others (1985) The Hofmeister effect and the behaviour of water at interfaces. Quart. rev. of biophysics, $18,1$.

Cowan, J.A., Upmacis, R.K., Beratan, D.N., Onuchic, J.N., and Gray, H.B. (1988) Long-range electron transfer in myoglobin. Ann N Y Acad Sci, 550, 68-84.

Cramer, W., and Knaff, D., (1990) Energy transduction in biological membranes: A textbook of bioenergetics. Springer-Verlag (New York).

Curry, W.B., Grabe, M.D., Kurnikov, I.V., Skourtis, S.S., Beratan, D.N., Regan, J.J., Aquino, A.J., Beroza, P., and Onuchic, J.N. (1995) Pathways, pathway tubes, 
pathway docking, and propagators in electron transfer proteins. J Bioenerg Biomembr, 27, 285-293.

Cusanovich, M.A., and Meyer, T.E. (2003) Photoactive yellow protein: a prototypic PAS domain sensory protein and development of a common signaling mechanism. Biochemistry, 42, 4759-4770.

Czege, J., and Kovacs, K.L. (1989) Transient kinetics of flavocytochrome $c$ photoreduction by methyl viologen. Photochemistry and Photobiology, 50, 697-700.

DeLano, W., and Scientific, D. (2002) Pymol: An open-source molecular graphics tool. CCP4 Newsletter On Protein Crystallography, 40.

Devanathan, S., Genick, U.K., Canestrelli, I.L., Meyer, T.E., Cusanovich, M.A., Getzoff, E.D., and Tollin, G. (1998) New insights into the photocycle of Ectothiorhodospira halophila photoactive yellow protein: photorecovery of the longlived photobleached intermediate in the Met100Ala mutant. Biochemistry, 37, 1156311568.

DeVault, D., and Chance, B. (1966) Studies of photosynthesis using a pulsed laser. I. Temperature dependence of cytochrome oxidation rate in chromatium. Evidence for tunneling. Biophys J, 6, 825-47.

DeVault, D., and Sutin, N. (1980) Quantum mechanical tunnelling in biological systems. Quarterly Reviews of Biophysics, 13, 387-564.

Di Bilio, A., Hill, M., Bonander, N., Karlsson, B., Villahermosa, R., Malmström, B., Winkler, J., and Gray, H. (1997) Reorganization energy of blue copper: Effects of temperature and driving force on the rates of electron transfer in ruthenium-and osmium-modified azurins. Journal of the American Chemical Society, 119, 9921-9922.

Dioumaev, A.K., and Lanyi, J.K. (2008) Switch from conventional to distributed kinetics in the bacteriorhodopsin photocycle. Biochemistry, 47, 11125-11133.

Durham, B., and Millett, F. (2012) Design of photoactive ruthenium complexes to study electron transfer and proton pumping in cytochrome oxidase. Biochim Biophys Acta, 1817,567-74.

Dér, A. (2008) Salts, Interfacial Water and Protein Conformation. Biotechnology and biotechnological equipment, 22, 629. 
Dér, A., Kelemen, L., Fábián, L., Taneva, S.G., Fodor, E., Páli, T., Cupane, A., Cacace, M.G., and Ramsden, J.J. (2007) Interfacial water structure controls protein conformation. J Phys Chem B, 111, 5344-5350.

Düx, P., Rubinstenn, G., Vuister, G.W., Boelens, R., Mulder, F.A., HÃ ¥rd, K., Hoff, W.D., Kroon, A.R., Crielaard, W., Hellingwerf, K.J., and Kaptein, R. (1998) Solution structure and backbone dynamics of the photoactive yellow protein. Biochemistry, 37, 12689-99.

Engstrom, G., Rajagukguk, R., Saunders, A.J., Patel, C.N., Rajagukguk, S., Merbitz-Zahradnik, T., Xiao, K., Pielak, G.J., Trumpower, B., Yu, C.-A., Yu, L., Durham, B., and Millett, F. (2003) Design of a ruthenium-labeled cytochrome $c$ derivative to study electron transfer with the cytochrome $b c_{1}$ complex. Biochemistry, 42, 2816-2824.

Genick, U.K., Devanathan, S., Meyer, T.E., Canestrelli, I.L., Williams, E., Cusanovich, M.A., Tollin, G., and Getzoff, E.D. (1997) Active site mutants implicate key residues for control of color and light cycle kinetics of photoactive yellow protein. Biochemistry, 36, 8-14.

Gensch, T., Gradinaru, C., Van Stokkum, I., Hendriks, J., Hellingwerf, K., and van Grondelle, R. (2002) The primary photoreaction of photoactive yellow protein (PYP): anisotropy changes and excitation wavelength dependence. Chemical physics letters, $356,347-354$.

Geren, L., Durham, B., and Millett, F. (2009) Chapter 28 Use of ruthenium photoreduction techniques to study electron transfer in cytochrome oxidase. Methods Enzymol, 456, 507-520.

Geren, L.M., Beasley, J.R., Fine, B.R., Saunders, A.J., Hibdon, S., Pielak, G.J., Durham, B., and Millett, F. (1995) Design of a ruthenium-cytochrome $c$ derivative to measure electron transfer to the initial acceptor in cytochrome $c$ oxidase. J Biol Chem, 270, 2466-2472.

Gray, H., and Winkler, J. (1996a) Electron transfer in proteins. Annual review of biochemistry, $65,537-561$.

Gray, H.B., and Halpern, J. (2005) Distant charge transport. Proc Natl Acad Sci U 
S A, 102, 3533.

Gray, H.B., and Winkler, J.R. (1996b) Electron transfer in proteins. Annu Rev Biochem, 65, 537-561.

Harigai, M., Imamoto, Y., Kamikubo, H., Yamazaki, Y., and Kataoka, M. (2003) Role of an N-terminal loop in the secondary structural change of photoactive yellow protein. Biochemistry, 42, 13893-900.

Harigai, M., Kataoka, M., and Imamoto, Y. (2008) Interaction between N-terminal loop and beta-scaffold of photoactive yellow protein. Photochem Photobiol, 84, 10311037.

Heberle, J., and Gensch, T. (2001) When FT-IR spectroscopy meets X-ray crystallography. Nat Struct Biol, 8, 195-197.

Hellingwerf, K., Hendriks, J., and Gensch, T. (2003) Photoactive Yellow Protein, A New Type of Photoreceptor Protein: Will This "Yellow Lab" Bring Us Where We Want to Go?||. The Journal of Physical Chemistry A, 107, 1082-1094.

Hendriks, J., and Hellingwerf, K.J. (2009) pH Dependence of the photoactive yellow protein photocycle recovery reaction reveals a new late photocycle intermediate with a deprotonated chromophore. J Biol Chem, 284, 5277-88.

Hendriks, J., van Stokkum, I.H., and Hellingwerf, K.J. (2003) Deuterium isotope effects in the photocycle transitions of the photoactive yellow protein. Biophys J, 84, $1180-91$.

Henry, E., and Hofrichter, J. (2010) Singular value decomposition: application to analysis of experimental data. Essential Numerical Computer Methods, , 81.

Hoersch, D., Otto, H., Joshi, C.P., Borucki, B., Cusanovich, M.A., and Heyn, M.P. (2007) Role of a conserved salt bridge between the PAS core and the N-terminal domain in the activation of the photoreceptor photoactive yellow protein. Biophys J, 93, 168799.

Hoff, W.D., van der Horst, M.A., Nudel, C.B., and Hellingwerf, K.J. (2009) Prokaryotic phototaxis. Methods Mol Biol, 571, 25-49.

Hopfield, J.J. (1974) Electron transfer between biological molecules by thermally 
activated tunneling. Proc Natl Acad Sci U S A, 71, 3640-3644.

van der Horst, M.A., van Stokkum, I.H., Crielaard, W., and Hellingwerf, K.J. (2001) The role of the N-terminal domain of photoactive yellow protein in the transient partial unfolding during signalling state formation. FEBS Lett, 497, 26-30.

Hoshihara, Y., Imamoto, Y., Kataoka, M., Tokunaga, F., and Terazima, M. (2008) Conformational changes in the N-terminal region of photoactive yellow protein: a timeresolved diffusion study. Biophys J, 94, 2187-93.

Ihee, H., Rajagopal, S., Srajer, V., Pahl, R., Anderson, S., Schmidt, M., Schotte, F., Anfinrud, P.A., Wulff, M., and Moffat, K. (2005) Visualizing reaction pathways in photoactive yellow protein from nanoseconds to seconds. Proc Natl Acad Sci U S A, $102,7145-50$.

Imamoto, Y., Kataoka, M., and Tokunaga, F. (1996) Photoreaction cycle of photoactive yellow protein from Ectothiorhodospira halophila studied by lowtemperature spectroscopy. Biochemistry, 35, 14047-14053.

Joshi, C.P., Borucki, B., Otto, H., Meyer, T.E., Cusanovich, M.A., and Heyn, M.P. (2005) Photoreversal kinetics of the $I_{1}$ and $I_{2}$ intermediates in the photocycle of photoactive yellow protein by double flash experiments with variable time delay. Biochemistry, 44, 656-65.

Joshi, C.P., Borucki, B., Otto, H., Meyer, T.E., Cusanovich, M.A., and Heyn, M.P. (2006) Photocycle and photoreversal of photoactive yellow protein at alkaline $\mathrm{pH}$ : kinetics, intermediates, and equilibria. Biochemistry, 45, 7057-68.

Kawatsu, T., Kakitani, T., and Yamato, T. (2001) Worm model for electron tunneling in proteins: consolidation of the pathway model and the Dutton plot. The Journal of Physical Chemistry B, 105, 4424-4435.

Keilin, D. (1925) On cytochrome, a respiratory pigment, common to animals, yeast, and higher plants. Proceedings of the Royal Society of London. Series B, Containing Papers of a Biological Character, 98, 312-339.

Keilin, D., (1966) History of cell respiration and cytochrome.[Cell respiration and cytochrome]. Cambridge University Press. Cambridge.

King, T. (1967) The keilin-hartree heart muscle preparation. Methods in 
Enzymology, 10, 202-208.

Koradi, R., Billeter, M., and Wüthrich, K. (1996) MOLMOL: a program for display and analysis of macromolecular structures. J Mol Graph, 14, 51-5, 29-32.

Kort, R., Vonk, H., Xu, X., Hoff, W.D., Crielaard, W., and Hellingwerf, K.J. (1996) Evidence for trans-cis isomerization of the p-coumaric acid chromophore as the photochemical basis of the photocycle of photoactive yellow protein. FEBS Lett, 382, 73-78.

Kotlyar, A., Borovok, N., Hazani, M., Szundi, I., and Einarsdattir, O. (2000) Photoinduced intracomplex electron transfer between cytochrome $c$ oxidase and TUPSmodified cytochrome $c$. Eur J Biochem, 267, 5805-9.

Kotlyar, A., Borovok, N., Raviv, S., Zimanyi, L., and Gutman, M. (1996) Fast redox perturbation of aqueous solution by photoexcitation of pyranine. Photochemistry and photobiology, 63, 448-454.

Kotlyar, A.B., and Borovok, N. (1997) Intramolecular oxidation of cytochrome $c$ by covalently attached sulfoaromatic molecules. Biochimica et Biophysica Acta (BBA) - Bioenergetics, 1321, 221 - 228.

Kotlyar, A.B., Borovok, N., and Hazani, M. (1997a) Use of thiouredopyrenetrisulfonate photochemistry for driving electron transfer reactions in aqueous solutions. Biochemistry, 36, 15823-7.

Kotlyar, A.B., Borovok, N., and Hazani, M. (1997b) Photoinduced electron transfer in singly labeled thiouredopyrenetrisulfonate cytochrome $c$ derivatives. Biochemistry, 36, 15828-33.

Kunz, W., Henle, J., and Ninham, B. (2004) 'Zur Lehre von der Wirkung der Salze'(about the science of the effect of salts): Franz Hofmeister's historical papers. Current opinion in colloid \& interface science, 9, 19-37.

Kurnikov, I. (2001). HARLEM (HAmiltonians to Research LargE Molecules). software package. Available http://www.kurnikov.org/harlem_manual/html/index.html.

de la Lande, A., Babcock, N.S., Rezác, J., Sanders, B.C., and Salahub, D.R. (2010) Surface residues dynamically organize water bridges to enhance electron transfer between proteins. Proc Natl Acad Sci U S A, 107, 11799-11804. 
Lee, B.C., and Hoff, W.D. (2008) Proline 54 trans-cis isomerization is responsible for the kinetic partitioning at the last-step photocycle of photoactive yellow protein. Protein Sci, 17, 2101-10.

Lee, J., Chang, I., Gray, H., Winkler, J., and others (2002) The cytochrome $c$ folding landscape revealed by electron-transfer kinetics. Journal of molecular biology, $320,159-164$.

Liu, X., Kim, C.N., Yang, J., Jemmerson, R., and Wang, X. (1996) Induction of apoptotic program in cell-free extracts: requirement for dATP and cytochrome $c$. Cell, $86,147-157$.

Marcus, R. (1997) Electron transfer reactions in chemistry: theory and experiment. NOBEL LECTURES IN CHEMISTRY 1991-1995, 69.

Marcus, R., and Sutin, N. (1985) Electron transfers in chemistry and biology. Biochim. Biophys. Acta, 811, 265-322.

Margoliash, E., and Lustgarten, J. (1962) Interconversion of horse heart cytochrome $c$ monomer and polymers. J Biol Chem, 237, 3397-405.

Margoliash, E., and Schejter, A. (1966) Cytochrome c. Adv Protein Chem, 21, $113-286$.

McIntosh, B.E., Hogenesch, J.B., and Bradfield, C.A. (2010) Mammalian PerArnt-Sim proteins in environmental adaptation. Annu Rev Physiol, 72, 625-645.

Meyer, T.E. (1985) Isolation and characterization of soluble cytochromes, ferredoxins and other chromophoric proteins from the halophilic phototrophic bacterium Ectothiorhodospira halophila. Biochim Biophys Acta, 806, 175-183.

Meyer, T.E., Tollin, G., Hazzard, J.H., and Cusanovich, M.A. (1989) Photoactive yellow protein from the purple phototrophic bacterium, Ectothiorhodospira halophila. Quantum yield of photobleaching and effects of temperature, alcohols, glycerol, and sucrose on kinetics of photobleaching and recovery. Biophys J, 56, 559-64.

Millett, F., and Durham, B. (2002) Design of photoactive ruthenium complexes to study interprotein electron transfer. Biochemistry, 41, 11315-11324.

Mori, Y., Shinoda, H., Nakano, T., and Kitagawa, T. (2002a) Formation and Decay 
Behaviors of Laser-Induced Transient Species from Pyrene Derivatives 2. Micellar Effects. The Journal of Physical Chemistry A, 106, 11750-11759.

Mori, Y., Shinoda, H., Nakano, T., and Kitagawa, T. (2002b) Formation and decay behaviors of laser-induced transient species from pyrene derivatives 1. Spectral discrimination and decay mechanisms in aqueous solution. The Journal of Physical Chemistry A, 106, 11743-11749.

Mori, Y., Shinoda, H., Nakano, T., and Kitagawa, T. (2003) Laser photolysis of pyrenesulfonate and pyrenetetrasulfonate via two-photon ionization in aqueous and reverse micellar solutions. Journal of Photochemistry and Photobiology A: Chemistry, $157,33-38$.

Moser, C.C., Chobot, S.E., Page, C.C., and Dutton, P.L. (2008) Distance metrics for heme protein electron tunneling. Biochim Biophys Acta, 1777, 1032-7.

Moser, C.C., Keske, J.M., Warncke, K., Farid, R.S., and Dutton, P.L. (1992) Nature of biological electron transfer. Nature, 355, 796-802.

Moser, C.C., Page, C.C., Chen, X., and Dutton, P.L. (2000) Electron transfer in natural proteins theory and design. Subcell Biochem, 35, 1-28.

Moser, C.C., Page, C.C., and Dutton, P.L. (2006) Darwin at the molecular scale: selection and variance in electron tunnelling proteins including cytochrome $c$ oxidase. Philos Trans R Soc Lond B Biol Sci, 361, 1295-1305.

Neagu, A., Neagu, M., and Der, A. (2001a) Active transport modulated by barrier fluctuations. NATO SCIENCE SERIES SUB SERIES I LIFE AND BEHAVIOURAL SCIENCES, 335, 225-243.

Neagu, A., Neagu, M., and Dér, A. (2001b) Fluctuations and the Hofmeister effect. Biophysical journal, 81, 1285-1294.

Nostro, P.L., and Ninham, B.W. (2012) Hofmeister Phenomena: An Update on Ion Specificity in Biology. Chem Rev.

Nostro, P.L., Ninham, B.W., Milani, S., Nostro, A.L., Pesavento, G., and Baglioni, P. (2006) Hofmeister effects in supramolecular and biological systems. Biophys Chem, $124,208-213$. 
Ow, Y.-L.P., Green, D.R., Hao, Z., and Mak, T.W. (2008) Cytochrome $c$ : functions beyond respiration. Nat Rev Mol Cell Biol, 9, 532-542.

Parak, F., and Frauenfelder, H. (1993) Protein dynamics. Physica A: Statistical Mechanics and its Applications, 201, 332-345.

Parsons, D.F., Boström, M., Nostro, P.L., and Ninham, B.W. (2011) Hofmeister effects: interplay of hydration, nonelectrostatic potentials, and ion size. Phys Chem Chem Phys, 13, 12352-12367.

Pellequer, J.L., Wager-Smith, K.A., Kay, S.A., and Getzoff, E.D. (1998) Photoactive yellow protein: a structural prototype for the three-dimensional fold of the PAS domain superfamily. Proc Natl Acad Sci U S A, 95, 5884-5890.

Peterson-Kennedy, S., McGourty, J., and Hoffman, B. (1984) Temperature dependence of long-range electron transfer in [Zn, FeIII] hybrid hemoglobin. Journal of the American Chemical Society, 106, 5010-5012.

Pinheiro, T. (1994) The interaction of horse heart cytochrome $c$ with phospholipid bilayers. Structural and dynamic effects. Biochimie, 76, 489-500.

Ponting, C.P., and Aravind, L. (1997) PAS: a multifunctional domain family comes to light. Current Biology, 7, R674 - R677.

Rajagopal, S., Anderson, S., Srajer, V., Schmidt, M., Pahl, R., and Moffat, K. (2005) A structural pathway for signaling in the E46Q mutant of photoactive yellow protein. Structure, 13, 55-63.

Regan, J., Risser, S., Beratan, D., and Onuchic, J. (1993) Protein electron transport: single versus multiple pathways. The Journal of Physical Chemistry, 97, 13083-13088.

Rubinstenn, G., Vuister, G.W., Mulder, F.A., Düx, P.E., Boelens, R., Hellingwerf, K.J., and Kaptein, R. (1998) Structural and dynamic changes of photoactive yellow protein during its photocycle in solution. Nat Struct Biol, 5, 568-570.

Ruitenberg, M., Kannt, A., Bamberg, E., Ludwig, B., Michel, H., and Fendler, K. (2000) Single-electron reduction of the oxidized state is coupled to proton uptake via the $\mathrm{K}$ pathway in Paracoccus denitrificans cytochrome $c$ oxidase. Proceedings of the National Academy of Sciences, 97, 4632. 
Schmidt, M., Pahl, R., Srajer, V., Anderson, S., Ren, Z., Ihee, H., Rajagopal, S., and Moffat, K. (2004) Protein kinetics: structures of intermediates and reaction mechanism from time-resolved x-ray data. Proc Natl Acad Sci U S A, 101, 4799-4804.

Schotte, F., Cho, H.S., Kaila, V.R.I., Kamikubo, H., Dashdorj, N., Henry, E.R., Graber, T.J., Henning, R., Wulff, M., Hummer, G., Kataoka, M., and Anfinrud, P.A. (2012) Watching a signaling protein function in real time via 100-ps time-resolved Laue crystallography. Proc Natl Acad Sci U S A, 109, 19256-19261.

Sergi, A., Grüning, M., Ferrario, M., and Buda, F. (2001) Density functional study of the photoactive yellow protein's chromophore. The Journal of Physical Chemistry B, 105, 4386-4391.

Shastry, M., Sauder, J., and Roder, H. (1998) Kinetic and structural analysis of submillisecond folding events in cytochrome $c$. Accounts of chemical research, 31, 717725.

Shimizu, N., Kamikubo, H., Mihara, K., Imamoto, Y., and Kataoka, M. (2002) Effect of organic anions on the photoreaction of photoactive yellow protein. J Biochem, $132,257-63$.

Sola, M., Cowan, J.A., and Gray, H.B. (1989) 1H NMR characterization of Chromatium gracile high-potential iron protein and its ruthenium-modified derivatives. Modulation of the reduction potentials in low- and high-potential [Fe4S4] ferredoxins. Biochemistry, 28, 5261-5268.

Sprenger, W.W., Hoff, W.D., Armitage, J.P., and Hellingwerf, K.J. (1993) The eubacterium Ectothiorhodospira halophila is negatively phototactic, with a wavelength dependence that fits the absorption spectrum of the photoactive yellow protein. $\mathrm{J}$ Bacteriol, 175, 3096-3104.

Steinbach, P., Ionescu, R., and Matthews, C. (2002) Analysis of kinetics using a hybrid maximum-entropy/nonlinear-least-squares method: application to protein folding. Biophysical journal, 82, 2244-2255.

Sétif, P.Q., and Bottin, H. (1995) Laser flash absorption spectroscopy study of ferredoxin reduction by photosystem I: spectral and kinetic evidence for the existence of several photosystem I-ferredoxin complexes. Biochemistry, 34, 9059-9070. 
Tenger, K., Khoroshyy, P., Leitgeb, B., Rákhely, G., Borovok, N., Kotlyar, A., Dolgikh D.A. and Zimányi L. (2005) Complex kinetics of the electron transfer between the photoactive redox label TUPS and the heme of cytochrome $c$. J. Chem. Inf. Mod. 45(6):1520-1526.

Tenger, K., Khoroshyy, P., Kovacs, K.L., Zimanyi, L., and Rakhely, G. (2007) Improved system for heterologous expression of cytochrome $c$ mutants in Escherichia coli. Acta Biol Hung, 58 Suppl, 23-35.

Theorell, H., and Åkesson, Å. (1941) Studies on Cytochrome c. II. The Optical Properties of Pure Cytochrome $c$ and Some of Its Derivatives. Journal of the American Chemical Society, 63, 1812-1818.

Tripathi, S., Srajer, V., Purwar, N., Henning, R., and Schmidt, M. (2012) pH dependence of the photoactive yellow protein photocycle investigated by time-resolved crystallography. Biophys J, 102, 325-332.

Turro, N., (1978) Modern molecular photochemistry. Benjamin, New York.

Turro, N., (1991) Modern molecular photochemistry. Univ. Science Books.

Ujj, L., Devanathan, S., Meyer, T.E., Cusanovich, M.A., Tollin, G., and Atkinson, G.H. (1998) New photocycle intermediates in the photoactive yellow protein from Ectothiorhodospira halophila: picosecond transient absorption spectroscopy. Biophys J, 75, 406-412.

Vreede, J., Hellingwerf, K.J., and Bolhuis, P.G. (2008) Helix formation is a dynamical bottleneck in the recovery reaction of Photoactive Yellow Protein. Proteins, 72, 136-49.

Xie, A., Hoff, W.D., Kroon, A.R., and Hellingwerf, K.J. (1996) Glu46 donates a proton to the 4-hydroxycinnamate anion chromophore during the photocycle of photoactive yellow protein. Biochemistry, 35, 14671-8.

Xie, A., Kelemen, L., Hendriks, J., White, B.J., Hellingwerf, K.J., and Hoff, W.D. (2001) Formation of a new buried charge drives a large-amplitude protein quake in photoreceptor activation. Biochemistry, 40, 1510-7.

Yeremenko, S., van Stokkum, I.H., Moffat, K., and Hellingwerf, K.J. (2006) Influence of the crystalline state on photoinduced dynamics of photoactive yellow 
protein studied by ultraviolet-visible transient absorption spectroscopy. Biophys J, 90, 4224-35.

Yonetani, T. (1967) Cytochrome oxidase: Beef Heart. Methods in Enzymology, $10,332-335$.

Yoshikawa, S., Choc, M., O'Toole, M., Caughey, W., and others (1977) An infrared study of $\mathrm{CO}$ binding to heart cytochrome $c$ oxidase and hemoglobin A. Implications re O2 reactions. The Journal of biological chemistry, 252, 5498.

Zhang, Y., and Cremer, P.S. (2006) Interactions between macromolecules and ions: The Hofmeister series. Curr Opin Chem Biol, 10, 658-663. 
List of publications.

\section{List of publications.}

\section{In extenso publications which are related to this dissertation:}

Khoroshyy, P. Dér, A., and Zimányi, L. (2013) Effect of Hofmeister cosolutes on the photocycle of photoactive yellow protein at moderately alkaline $\mathrm{pH}$. J. Photochem. Photobiol. B, in press (http://dx.doi.org/10.1016/j.jphotobiol.2012.12.014) (IF 2.413)

Tenger, K., Khoroshyy, P., Leitgeb, B., Rákhely, G., Borovok, N., Kotlyar, A., Dolgikh D.A. and Zimányi L. (2005) Complex kinetics of the electron transfer between the photoactive redox label TUPS and the heme of cytochrome c. J. Chem. Inf. Mod. 45(6):1520-1526 (IF 4.675)

Kotlyar, A.B., Borovok, N., Khoroshyy, P., Tenger, K. and Zimányi, L. (2004) Redox photochemistry of thiouredopyrenetrisulfonate. Photochem. Photobiol. 79(6):489-493 (IF 2.413)

\section{Other in extenso publications:}

Hajdu, K., Gergely, Cs., Martin, M., Cloitre, T., Zimányi, L., Tenger, K., Khoroshyy, P., Palestino, A., Agarwal, V., Hernádi K., Németh, Z., and Nagy, L. (2012) Porous silicon/photosynthetic reaction center hybrid nanostructure. Langmuir 28(32):1866-11873 (IF 4.186)

Zimányi, L., Khoroshyy, P., and Mair, T. (2010) A chemometric method to identify enzymatic reactions leading to the transition from glycolytic oscillations to waves. Physica D 239(11):866-872 (IF 1.594)

Tenger, K., Khoroshyy, P., Rákhely, G. and Zimányi, L. (2010) Maturation of a eukaryotic cytochrome $\mathrm{c}$ in the cytoplasm of Escherichia coli without the assistance by a dedicated biogenesis apparatus. J. Bioenerg. Biomemb. 42:125\#133 (IF 2.813)

Tenger, K., Khoroshyy, P., Kovács, K.L., Zimányi, L. and Rákhely, G. (2007) Improved system for heterologous expression of cytochrome c mutants in Escherichia coli. Acta Biol. Hung. 58:23-35 (IF 0.59)

Mair, T., Zimányi, L., Khoroshyy, P., Müller, A. and Müller, S.C. (2006) Analysis of the oscillatory kinetics of glycolytic intermediates in a yeast extract by FTIR spectroscopy. Biosystems 83:188-194 (IF 1.784) 
List of publications.

\section{Conference abstracts which are related to this thesis:}

Zimányi, L., Khoroshyy, P., and Dér, A. (2011) Hofmeister salt effects on the photocycle dynamics of photoactive yellow protein. 7th International Conference for Biological Physics, San Diego, USA, p.116.

Khoroshyy, P., Dér, A. and Zimányi, L. (2011) Kinetic effect of Hofmeister ions on the photocycle of photoactive yellow protein. Eur. Biophys. J. 40(S1):208.

Khoroshyy, P., Tenger, K. and Zimányi, L. (2006) Intra- and interprotein photoinduced electron transfer in respiratory chain redox proteins. Biochim. Biophys. Acta 1757(14):187.

Tenger, K., Khoroshyy, P., Leitgeb, B., Rákhely, G., Borovok, N., Kotlyar, A. and Zimányi, L. (2005) Complex electron transfer kinetics between the photoactive label TUPS and the heme of cytochrome $c$. Eur. Biophys. J. 34(6):665.

Tenger, K., Rákhely, G., Khoroshyy, P., Leitgeb, B. és Zimányi, L. (2005) A fényindukált elektrontranszfer komplex kinetikája a fotoaktív redox jelölö, TUPS, és a citokróm $c$ hem kofaktora között. A Magyar Biofizikai Társaság 22. Kongresszusa, Debrecen, 2005. június 26-29.

\section{Other conference abstracts:}

Tenger, K., Khoroshyy, P., Rákhely, G. and Zimányi, L. (2008) Heterologous overexpression of eukaryotic cytochrome $c$ and cytochrome c heme lyase to study the mechanism of cytochrome c maturation. Biochim. Biophys. Acta 1777:S90.

Khoroshyy, P., Tenger, K. and Zimányi, L. (2008) Tuning the electron transfer rate by the redox potential of cytochrome $\mathrm{c}$ in complex with cytochrome $c$ oxidase. Biochim. Biophys. Acta 1777:S90.

Tenger, K., Khoroshyy, P., Kovács, K.L., Rákhely, G. and Zimányi, L. (2007) Heterologous overexpression of eukaryotic cytochrome $c$ and cytochrome c heme lyase in Escherichia coli for biophysical studies. Regional Biophysics Conference, Balatonfüred, Hungary, p.92.

Khoroshyy, P., Tenger, K. and Zimányi, L. (2007) Tuning of the electron transfer rate by the altered redox potential of heme $c$ in cytochrome $c$ and in its complex with cytochrome c oxidase. Regional Biophysics Conference, Balatonfüred, Hungary, p.114. 
List of publications.

Khoroshyy, P., Zimányi, L., Mair, T., Müller, A. and Müller, S.C. (2005) Chemometric analysis of the oscillatory kinetics of glycolytic intermediates in a yeast extract from data measured by FTIR-spectroscopy. Regional Biophysics Meeting, Zrece, Slovenia, p.89.

Tenger, K., Rákhely, G., Khoroshyy, P. and Zimányi, L. (2005) Expression, purification and labeling of recombinant horse cytochrome $c$, and measurements of photoinduced intraprotein electron transfer. Regional Biophysics Meeting, Zrece, Slovenia, p.61.

Zimányi, L., Tenger, K., Khoroshyy, P., Dolgikh, D., Siletsky, N., Borovok, N. and Kotlyar, A. (2004) Photoinduced electron transfer in cytochrome $c$ and cytochrome $c$ oxidase. Biochim. Biophys. Acta 13:158.

Khoroshyy, P., Tenger, K., Borovok, N., Kotlyar, A., Siletsky, S. and Zimányi, L. (2003) Electron transfer steps in the complex of cytochrome $c$ and cytochrome oxidase. 10th European Conference on the Spectroscopy of Biological Molecules, Szeged, Hungary, ISBN 963482614 8, p. 153.

Khoroshyy, P., Tenger, K., Borovok, N., Kotlyar, A. és Zimányi, L. (2003) Az elektrontranszfer lépései citokróm c és citokróm oxidáz komplexében. 33. MembránTranszport Konferencia, Sümeg, 2003. május 20-23. 


\section{Summary}

Inter- and intraprotein electron transfer is mostly known for its role in the bioenergetics of living organisms. Marcus theory relates the rate of electron transfer with its driving force (the free energy difference between the equilibrium states of the donor-acceptor pair before and after electron transfer) and the reorganisation energy. In addition, the rate of electron transfer decays exponentially with the distance between electron donor and acceptor. The corresponding distance decay constant depends on the medium between the donor and acceptor in a non-trivial way. A number of theories have been proposed to explain how the protein matrix controls the decay constant, and the collection of new experimental data may allow their refinement, and a better understanding of the process. Many electron transfer processes, resulting in redox state changes of molecules or cofactors, are reflected in their absorption spectrum, making kinetic absorption spectroscopy an appropriate tool of choice for their study. The introduction of TUPS (8-thiouredopyrene 1,3,6-trisulfonate) by Kotlyar et al. (1997a) provided an easily accessible, covalent photoactive redox label with the promise of the possibility to measure electron transfer processes both in the reductive and in the oxidative direction in non-photosynthetic systems. TUPS is a viable alternative to the widely used ruthenium complexes in the field due to its favourable properties: its long lived triplet excited state, its low redox potential and last, but not least, the relatively easy chemistry of its production from the precursor and of its attachment to either lysine or cysteine residues. After several publications by the inventors on the applicability of TUPS to induce protein reduction, our aim was to further study the photochemistry of TUPS in solution and investigate the possibility of using it in photoinduced protein oxidation. The natural choice for studies of the latter was mitochondrial cytochrome $c$, a simple, well characterized protein with a single heme as its redox center.

Using multichannel transient spectroscopy the interactions of TUPS in reductive and oxidative reactions were investigated. A new reaction for this dye has been characterised, where its excited triplet state serves as an oxidant, producing a reduced radical in the presence of a suitable electron donor. The characteristic difference and absolute spectra of the reduced radical of TUPS were determined, in addition to the previously known spectra of its triplet and positive radical. In anaerobic, redox neutral 
conditions in the presence of salt, the spectra recorded during the TUPS triplet decay reveal features of all three forms, as a result of the electron self-exchange between two TUPS molecules in their triplet excited states. Least-squares fits of the concentration profiles of the different forms with various models were tested in order to determine what processes are responsible for triplet decay and radical formation under such experimental conditions. The successful model includes the following processes: spontaneous triplet decay, triplet-triplet annihilation, electron transfer between triplets resulting in the formation of positive and negative radicals of TUPS, plus the reverse of the latter process, the recombination of the TUPS radicals.

The described oxidative properties of TUPS triplet suggested its applicability as a photoinduced covalent redox label, suitable for initiation not only reductive but also oxidative redox processes in biological systems. This has been demonstrated using the complex of TUPS with reduced cytochrome $c$, where the label was attached to a lysine at the $86^{\text {th }}$ position. Upon photoexcitation of this complex, TUPS triplet rapidly decays, as a result of electron transfer from the heme of cytochrome $c$ forming the reduced radical of TUPS and oxidized heme. The process is reversible. Detailed kinetic analysis of the forward and reverse electron transfer has shown that the re-reduction of the heme by the TUPS negative radical is faster than its initial oxidation, thereby preventing the accumulation of the transient products in large quantities.

To investigate the distance dependence of the electron transfer the TUPS label has been attached to two lysine residues (K8 and K39) at substantially different distances from the heme cofactor and on the opposite sides of horse heart cytochrome $c$. The photoinduced electron transfer between TUPS and the heme of cytochrome $c$ proved to be more complicated than predicted on the basis of the Marcus theory of electron transfer. While, at the available signal to noise ratio, forward electron transfer appeared roughly monoexponential, the reverse electron transfer clearly did not. The multiexponential behaviour could be explained by sample heterogeneity, which is, in fact, corroborated by the results of MD simulations. MD results have shown that the TUPS label is likely to occupy several geometrically feasible equilibrium positions, with different effective distances from the heme, and thereby the transferred electron 
may also experience various packing densities between the cofactors. Moreover, the calculated optimal electron transfer pathways do not involve the covalent link but proceed via through space jumps from the the protein surface to dye edge, effectively decoupling the length of the covalent link and the electron transfer rates.

Protein dynamics is an omnipresent phenomenon which, in many cases, is strongly coupled to function. Kinetic absorption spectroscopy is a useful tool to study phenomena related to protein dynamics if the processes can be initiated by short laser pulses and followed using the absorption changes of chromophores. One of the best systems for such studies is photoactive yellow protein (PYP) with its p-coumaric acid chromophore. This protein is a robust, strongly coloured molecule which serves as a prototype for G-protein coupled receptor signal transduction. Three distinct processes take place after its photoexcitation: the isomerization of the chromophore, the internal proton transfer from the E46 donor to the chromophore and a major conformational change to the signalling state, which involves partial unfolding of the protein. The reversible partial unfolding is expected to result in a substantial transient change in the water-exposed surface area of PYP. According to the theory of Dér et al. (2007) explaining the Hofmeister effect (HE) of certain anions on protein structural stability, such change of the hydrated protein surface must be affected thermodynamically by Hofmeister cosolutes. Therefore, the dynamic properties of PYP make it an excellent object to study experimentally the HE on the stability and reaction kinetics of proteins. In the second part of our work we were aiming to demonstrate the effective use of $\mathrm{HE}$ as a tool for the identification of crucial steps of protein function, involving major conformational changes.

Flash induced difference spectra mesured on PYP were analysed by a combination of chemometric methods, and five transitions were detected, providing evidence for five intermediates. The data allowed to distinguish two $\mathrm{pR}$ intermediates, which are spectrally rather similar but different kinetically. The presence of a red shifted shoulder in the $\mathrm{pB}_{1}$ spectrum indicated its coexistence with its alkaline form. Visual inspection of the absolute spectra showed the dominance of the blue shifted intermediate(s) at the end of the photocycle, but also the presence of the early red shifted intermediate(s). This 
suggests that an equilibrium between intermediates was formed. Finally, to cope with the biexponential recovery of the dark state, a spectrally silent intermediate, $\mathrm{pG}_{1}$ was required at the end of the photocycle. Taking into account these observations we proposed a sequential, generally reversible scheme of the PYP photocycle involving the $\mathrm{pR}_{1}, \mathrm{pR}_{2}, \mathrm{pB}_{1}, \mathrm{pB}_{2}$ and $\mathrm{pG}_{1}$ intermediates. This scheme was used in a global spectrotemporal model fit to the data obtained at different salt conditions, yielding the rate coefficients for the molecular transitions, the kinetic traces of intermediates and their final spectra.

Kosmotropic and chaotropic cosolutes influenced the formation and decay of, and the equilibria between photocycle intermediates in a systematic manner which follows the Hofmeister series of anions. Chaotropic salts prolong, kosmotropic salts shorten the duty cycle of the total $\mathrm{pB}$ form of PYP, as compared to the Hofmeister neutral $\mathrm{NaCl}$. The spectrotemporal least squares model fit to our data taken under different salt conditions provided more quantitative information, allowing to decipher the HE on the individual molecular transitions of the photocycle. While an opening of the protein conformation during $\mathrm{pB}_{1} \rightarrow \mathrm{pB}_{2}$ is in good agreement with our results, we have also pinpointed additional opening processes. These are hinted at by the monotonic acceleration of the rates while the salt cosolute changes from kosmotropes to chaotropes. The early $\mathrm{pR}_{1} \rightarrow \mathrm{pR}_{2}$ transition already exhibits such behaviour but, surprisingly, far the biggest effect is associated with the $\mathrm{pR}_{2} \rightarrow \mathrm{pB}_{1}$ transition. This transition coincides with the chromophore protonation and the hydratation of the chromophore pocket. Following Dér et al. (2007), the strongest effect of the Hofmeister salts on the rates of reactions is expected for processes involving large-scale waterexposed surface area changes. From this it could be concluded that in addition to the chromophore protonation, a conformational change associated with the exposure of hydrophobic residues of the protein should take place during this step. The recently observed increase of the diffusion coefficient of PYP in the same time domain fully supports this conclusion (Hoshihara et al., 2008). These authors attributed the corresponding conformational change to the unfolding of the N-terminal domain. Notably, the free energy difference between $\mathrm{pR}_{2}$ and $\mathrm{pB}_{1}$ does not seem to change significantly from chaotropes to kosmotropes. This follows from the fact that the salt 
dependence of the rate of the back reaction follows that of the forward process, so the stabilization of $\mathrm{pB}_{1}$ against $\mathrm{pR}_{2}$ is probably due to stochastic fluctuations of the energy barrier under the influence of cosolutes, as described in Neagu et al. (2001). In the $\mathrm{pB}_{1} \leftrightarrow \mathrm{pB}_{2}$ reaction, on the other hand, the equilibrium shifts towards $\mathrm{pB}_{2}$, in agreement with (Hoersch et al., 2007).

The detailed study of the Hofmeister effects on the kinetics and transient equilibria in the PYP photocycle has proven that the HE is a useful tool in finding and characterizing large scale protein conformational changes. In particular, based on our results and relevant data of the literature, we can suggest the following scenario for the structural changes during the PYP photocycle (after the formation of $\mathrm{pR}_{1}$ ):

$\mathrm{pR}_{1} \rightarrow \mathrm{pR}_{2}$ : conformational relaxation (opening) after isomerization

$\mathrm{pR}_{2} \rightarrow \mathrm{pB}_{1}$ : large-scale conformational opening with exposure of hydrophobic residues to the water (unfolding of the $\mathrm{N}$-terminal domain, coinciding with the protonation of the chromophore)

$\mathrm{pB}_{1} \rightarrow \mathrm{pB}_{2}$ : further conformational opening (changes in the PAS core and the $\beta$ scaffold)

$\mathrm{pB}_{2} \rightarrow \mathrm{pG}_{1}$ : conformational refolding (coinciding with the deprotonation of the chromophore)

$\mathrm{pG}_{1} \rightarrow \mathrm{pG}$ : reisomerization of the chromophore, final refolding to terminate the photocycle. 


\section{1 Összefoglalás}

A fehérjéken belüli és a fehérjék közötti elektrontranszfer főleg az élő szervezetek energiaháztartásában betöltött szerepéről ismert. A Marcus elmélet kapcsolatot teremt az elektrontranszfer sebessége, valamint annak hajtóereje (a donor-akceptor pár elektrontranszfer előtti és utáni egyensúlyi állapotának szabadentalpia-különbsége) és a reorganizációs energia között. Ezenfelül az elektrontranszfer sebessége exponenciálisan csökken a donor és akceptor közötti távolsággal. Az ezt jellemző lecsengési állandó nem triviális módon függ a donort és akceptort összekötő közegtől is. Több elméletet javasoltak már arra vonatkozóan, hogy a fehérje anyaga hogyan szabályozza a lecsengési állandót, és bármilyen új kísérleti adat hozzásegíthet a folyamatok jobb megértéséhez, az elmélet finomításához. Számos elektrontranszfer folyamat, mely molekulák vagy kofaktorok redox állapotának változását eredményezi, egyben ezek abszorpciós spektrumában is változást okoz, és így lehetővé válik a jelenség kinetikus abszorpciós spektroszkópiával való nyomon követése. A TUPS (8-thiouredopyrene 1,3,6-trisulfonate) molekula (Kotlyar és mtsi. 1997a) olyan ígéretes, könnyen hozzáférhető, kovalens fotoaktív redox jelölőt adott a kezünkbe, mellyel megnyílt a lehetősége nem-fotoszintetikus rendszerekben az elektrontranszfer folyamatok mérésének mind reduktív, mind oxidatív irányban. A TUPS komoly alternatívája a széleskörüen alkalmazott ruténium komplexeknek, mégpedig előnyös tulajdonságai miatt; ezek a hosszú élettartamú triplet gerjesztett állapota, az alacsony redoxpotenciálja és végül, de nem utolsó sorban, a prekurzorból való előállításának és a lizin vagy cisztein oldalláncokhoz való kötésének viszonylagos egyszerüsége. A TUPS bevezetőinek néhány publikációja után, melyekben a jelölő alkalmasságáról számoltak be fehérjék redukciójának kiváltására, célunk volt a TUPS fotokémiájának részletes tanulmányozása oldatban, illetve annak vizsgálata, hogy használható-e fényindukált fehérje-oxidációra is. Ehhez természetes választásnak adódott az egyetlen hemet, mint redox kofaktort tartalmazó, viszonylag egyszerü és igen részletesen ismert mitokondriális citokróm c fehérje.

Vizsgáltuk a TUPS kölcsönhatásait oxidatív és reduktív folyamatokban sokcsatornás tranziens abszorpciós spektroszkópia módszerével. A festék új reakcióját írtuk le, ahol annak gerjesztett triplet állapota megfelelő elektrondonor jelenlétében 
oxidánsként müködik, és így előáll a TUPS negatív gyöke. Meghatároztuk a TUPS negatív gyök jellemző abszorpciós és differenciaspektrumát, ezzel kiegészítve a már ismert spektrumok (a triplet és a pozitív ion) körét. Anaerób és redox-semleges körülmények között, só jelenlétében, a TUPS gerjesztett triplet lecsengése során mért spektrumok mindhárom forma jelenlétét mutatták, ezzel igazolva, hogy a triplet gerjesztett állapotban lévő molekulák elektronkicserélődésre képesek. A kiszámolt koncentráció-profilok legkisebb négyzetes illesztésével arra kerestük a választ, hogy a lehetséges modellek közül melyik írja le helyesen a triplet lecsengésének és a pozitív és negatív ionok kialakulásának folyamatát az adott kísérleti körülmények között. A sikeres modell a következö lépéseket tartalmazta: a triplet spontán lecsengése, triplettriplet annihiláció, tripletek közötti elektrontranszfer, melynek eredménye egy pozitív és egy negatív ion, illetve ennek fordítottja, a kialakult gyökök semlegesítése (rekombinációja) elektrontranszfer útján.

A TUPS általunk leírt oxidatív tulajdonsága arra utalt, hogy olyan kovalens fényindukált jelölőként is használható lehet, mely biológiai rendszerekben nemcsak reduktív, hanem oxidatív irányú elektrontranszfert is képes elindítani. Ezt a TUPS-nak redukált citokróm c-vel való komplexében igazoltuk, ahol a jelölő a 86. pozícióban lévő lizin oldallánchoz volt kötve. A minta fénnyel való gerjesztése után megfigyeltük a triplet gyors lecsengését, és ezzel egyidejüleg a TUPS negatív gyök, valamint az oxidált hem megjelenését, nyilvánvaló módon elektrontranszfer eredményeképpen. A folyamat reverzibilisnek bizonyult. Az eredeti és a fordított elektrontranszfer részletes kinetikai analízise megmutatta, hogy a hem redukciója a TUPS negatív ion által gyorsabb, mint az eredeti oxidációja a TUPS triplet által. Ez magyarázza az átmeneti termékek csak kismértékủ felhalmozódását.

Az elektrontranszfer távolságfüggésének vizsgálatához a TUPS-ot a ló szív citokróm c két lizin oldalláncához (K8 és K39) kapcsoltuk. Ezek távolsága a hemtől jelentősen eltér, ráadásul a hemhez képest a fehérje két átellenes felszínén helyezkednek el. A TUPS és a hem közötti fényindukált elektrontranszfer bonyolultabbnak bizonyult, mint azt az elektrontranszfer Marcus elmélete alapján jósolni lehetett. Míg (az adott jel/zaj viszony mellett) az elöremenő elektrontranszfer egyetlen exponenciálissal volt 
közelíthető, a visszafelé irányuló elektrontranszfer határozottan nem. A multiexponenciális viselkedést a minta heterogenitásával lehetett értelmezni, és ezt később molekuladinamikai számítások is megerősítették. A MD eredmények azt mutatták, hogy a TUPS valószínüleg több, geometriailag különbözö egyensúlyi helyzetet képes elfoglalni a fehérjéhez képest, ezeknek a hemtől való effektív távolsága eltérő lehet, és az elektron is különböző fehérjesürüségeket „érezhet” az elektrontranszfer során. Továbbá, a kiszámított optimális elektrontranszfer útvonalak nem a kovalens összeköttetés mentén haladtak, hanem a festék és a fehérje felszíne között térbeli ugrással. Ezzel megmutattuk, hogy a kovalens összeköttetés hossza és az elektrontranszfer sebessége között ebben a rendszerben megszünik a szoros kapcsolat.

A fehérjék dinamikája olyan, mindenhol felbukkanó tulajdonság, amely sok esetben szorosan összekapcsolódik a fehérjék müködésével. A kinetikus abszorpciós spektroszkópia hasznos módszer lehet a fehérjedinamikával kapcsolatos folyamatok vizsgálatára minden olyan esetben, mikor a jelenségek gyors lézerimpulzussal indíthatóak, és fellép valamilyen kromofór(ok) abszorpcióváltozása. Ilyen vizsgálatokra az egyik legalkalmasabb rendszer a p-coumarinsavat, mint kromofórt tartalmazó fotoaktív sárga fehérje (PYP). Ez a robusztus, intenzív színű molekula a G-fehérjékhez kapcsolt jelátvivő receptorok prototípusa. Fénnyel való gerjesztése nyomán három folyamat játszódik le: a kromofór izomerizációja, belső protontranszfer az E46 donorról a kromofórra és a fehérje konformációjának megváltozása, mely a jeladó állapot kialakulásához vezet, és a fehérje részleges letekeredését eredményezi. Ez a reverzibilis, részleges kitekeredés várhatóan a fehérje víznek kitett felületének jelentős megnövekedésével jár együtt. A bizonyos anionok jelenlétében tapasztalható, a fehérjék szerkezeti stabilitását érintő Hofmeister hatás (HE) elméleti megalapozását jelentő elképzelés (Dér és mtsi., 2007) szerint a hidratált fehérjefelszín ilyen megváltozását a Hofmeister sók termodinamikailag befolyásolni tudják. Ennélfogva dinamikus tulajdonságai a PYP-et kiváló alanyává teszik a fehérjék stabilitását és reakciókinetikáját kutató kísérleti vizsgálatoknak. Munkánk második részében meg akartuk mutatni, hogy a HE hatékonyan felhasználható a fehérjék müködésében alapvetően fontos, jelentős konformációváltozásokkal együtt járó folyamatok azonosításában. 
A PYP-en mért fényimpulzus-indukált differenciaspektrumokat kemometriai módszerek kombinálásával értékeltük ki, és öt átmenetre találtunk bizonyítékot, ami azt mutatja, hogy a PYP fotociklusában öt intermedier lép fel. Az adatok alapján két pR intermediert lehetett megkülönböztetni, ezek spektrálisan meglehetősen hasonlóak, de kinetikailag különböznek. $\mathrm{A} \mathrm{pB}_{1}$ spektrumban talált vörös oldali váll ezen intermedier lúgos formájának a jelenlétére utalt. Az abszorpciós spektrumok a fotociklus végén a kékbe tolódott intermedierek túlsúlyát mutatták, de azért a korai, vörösbe tolódott formák jelenléte is megfigyelhető volt. Ez azt bizonyítja, hogy ezen itermedierek között termikus egyensúly alakul ki. Végezetül, annak érdekében, hogy a kiinduló állapot biexponenciális visszatérését meg lehessen magyarázni, egy spektrálisan „,csendes” $\mathrm{pG}_{1}$ intermedier fellépését kellett feltételezni a fotociklus végén. Mindezen megfigyelések összegzéseként egy szekvenciális, általában reverzibilis fotociklus sémát javasoltunk, mely a $\mathrm{pR}_{1}, \mathrm{pR}_{2}, \mathrm{pB}_{1}, \mathrm{pB}_{2}$ és $\mathrm{pG}_{1}$ intermediereket tartalmazta. Ezt a sémát használtuk aztán a különböző sók jelenlétében felvett adatok globális modellillesztése során (spektrális és kinetikus paraméterek egyidejü illesztésével), és eredményül megkaptuk a molekuláris átmenetek sebességi állandóit, továbbá az egyes intermedierek kinetikáját és abszorpciós spektrumát.

A kozmotróp és a kaotróp sók szisztematikus módon befolyásolták a fotociklus intermedierek kialakulását és lecsengését, valamint a köztük fellépő egyensúlyokat. Ez a szisztematikus hatás az anionok Hofmeister-sorát követte. A kaotrópok meghosszabbították, a kozmotrópok lerövidítették a teljes pB intermedier életidejét, a semleges NaCl-hez hasonlítva. A különböző körülmények között felvett adatok spektrális-időbeli modellillesztése részletes kvantitatív eredményeket szolgáltatott, lehetővé téve a fotociklus egyes molekuláris átmeneteinek esetében fellépő HE feltárását. Egyrészt, eredményeinkkel jól összhangban áll a $\mathrm{pB}_{1} \rightarrow \mathrm{pB}_{2}$ átmenet során fellépő, a fehérje kinyílásával járó, irodalomból ismert jelentős konformációváltozás. Ugyanakkor egyéb átmeneteket is találtunk, melyek sebességének monoton növekedése a kozmotróp sóktól a kaotrópok felé haladva a fehérje kinyílására utal. Már a korai $\mathrm{pR}_{1} \rightarrow \mathrm{pR}_{2}$ átmenet is így viselkedik, de meglepő módon messze a legnagyobb hatást a $\mathrm{pR}_{2} \rightarrow \mathrm{pB}_{1}$ átmenet esetén tapasztaltuk. Ez egybeesik a kromofór protonációjával, és a kromofór ,zsebének” hidratációjával. Dér és mtsi. (2007) szerint a reakciósebességekre 
kifejtett legnagyobb Hofmeister hatás akkor várható, amikor a fehérje vízzel érintkező felülete a leginkább változik. Ebböl arra következtethetünk, hogy ezen lépés során a kromofór protonációja mellett olyan konformációváltozás történik, mely a fehérje hidrofób tartományainak a vizes fázissal való érintkezését növeli meg. Ez összhangban áll azzal az eredménnyel (Hoshihara és mtsi., 2008), hogy ugyanebben az időtartományban a PYP diffúziós állandója megnő, feltehetőleg az N-terminális fehérjedomén kitekeredése miatt. Érdekes az, hogy eredményeink szerint a $\mathrm{pR}_{2}$ és $\mathrm{pB}_{1}$ formák közötti szabadentalpia-különbség nem függ a jelenlevő kaotróp vagy kozmotróp sótól, hiszen az őket összekötő előremenő és fordított reakciók sebességi állandója párhuzamosan változik a sók függvényében. Tehát a $\mathrm{pB}_{1}$ stabilizációja a $\mathrm{pR}_{2}$-höz képest valószínüleg a köztük lévő potenciálgát sztochasztikus fluktuációjának köszönhető a Hofmeister sók függvényében (Neagu és mtsi., 2001). Ugyanakkor a $\mathrm{pB}_{1} \leftrightarrow \mathrm{pB}_{2}$ reakció során maga az egyensúly tolódik el a pB2 javára, összhangban az irodalommal (Hoersch és mtsi., 2007).

A Hofmeister hatás részletes tanulmányozása a PYP fotociklus kinetikájára és átmeneti egyensúlyaira bebizonyította, hogy a HE alkalmas eszköz a nagy fehérjekonformáció-változások kimutatására és jellemzésére. A PYP konkrét esetében, irodalmi adatokra és saját eredményeinkre támaszkodva az alábbi szerkezeti „eseményeket” tudtuk valószínüsíteni ezen fehérje müködése közben, a $\mathrm{pR}_{1}$ intermedier kialakulásától kezdődően:

$$
\begin{aligned}
& \mathrm{pR}_{1} \rightarrow \mathrm{pR}_{2} \text { : konformációs relaxáció (kinyílás) az izomerizáció után } \\
& \mathrm{pR}_{2} \rightarrow \mathrm{pB}_{1} \text { : nagy léptékü konformációs kinyílás, mely hidrofób oldalláncokat tesz }
\end{aligned}
$$
a vizes fázis számára hozzáférhetővé (az N-terminális domén kitekeredése, mely egybeesik a kromofór protonációjával)

$$
\mathrm{pB}_{1} \rightarrow \mathrm{pB}_{2} \text { : további konformációs kinyílás (változások a PAS “magban” és a } \beta \text { - }
$$
vázban)

$$
\mathrm{pB}_{2} \rightarrow \mathrm{pG}_{1} \text { : konformációs feltekeredés (mely egybeesik a kromofór }
$$
protonleadásával) 
Összefoglalás

$\mathrm{pG}_{1} \rightarrow$ pG: a kromofór reizomerizációja, a fehérje végső feltekeredése, ezzel a fotociklus lezárása. 